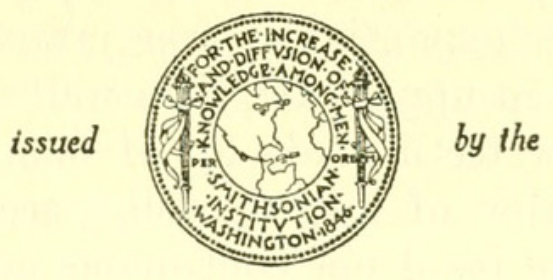

SMITHSONIAN INSTITUTION

U. S. NATIONAL MUSEUM

\title{
DESCRIPTIONS OF NEW FISHES OBTAINED BY THE UNITED STATES BUREAU OF FISHERIES STEAMER "ALBATROSS", CHIEFLY IN PHILIPPINE SEAS AND ADJACENT WATERS
}

\section{By Henry W. Fowler}

WHILE working in the United States National Museum with various groups of fishes representing chiefly the Berycoidei, Lophobranchii, Scombroidei, Loricati, Craniomi, and Eleotridae obtained by the Albatross, I ascertained a number of new genera and species. These are described and the species figured in the present paper.

The arrangement of the characters and their computation, formulas, and other data is the same as in previous reports on other sections of the collection. In locality references, the letter " $D$ " preceding a number refers to the Albatross dredging station, and the numbers in parentheses, as "(1567.)", refer to parchment tag numbers tied to the specimens.

\section{Family CHLOROPHTHALMIDAE}

\section{BATHYSAUROPS, new genus}

Type.-Bathysaurops malayanus, new species.

Body elongate, slender, with long tapering tail. Head large, depressed. Snout short, broad. Eye very large, high, with broad deep orbits, mostly in front half of head. Mouth large, inclined, lower jaw well protruded. Maxillary long, inferior, reaches back well below eye and terminally broadly expanded. Dentition of jaws exposed in closed jaws; above an outer band narrowly of very small teeth, then followed by 2 somewhat irregular rows of larger and 
longer well-spaced depressible teeth; all upper teeth extend to lower hind end of maxillary expansion; lower jaw with an outer band of teeth similar to those in upper jaw, then well separated and inside a narrow band of inner teeth made up of many very small close-set teeth with a single row of larger, well-spaced, firmly erect teeth; palatine and vomerine band not continuous across latter, with very narrow band or row of short, small, outer teeth and an inner closely following row of much larger, wide-set, strong, erect teeth; no teeth on tongue. Tongue small, flat, free. Nostrils together, posterior greatly larger, nearer eye than snout tip. Bony interorbital narrow, greatly less than eye. Gill opening widely cleft, extends forward opposite nostrils. Gill rakers slender. Pseudobranchiae well developed. Scales very caducous, most all fallen, thin cycloid. Axial series of scale pockets, evidently forming lateral line, greatly larger than others. Scales on caudal base small. Dorsal inserted before middle of depressed pectoral. Adipose fin small, well behind anal base. Caudal moderate. Pectoral long. Ventral inserted little before dorsal origin. Vent midway between depressed ventral tip and anal origin.

Differs from Bathysauropsis Regan in its greatly larger eyes, narrower interorbital space, apparently larger scales in the lateral line, and slightly different proportions.

(Bathysaurus $+\ddot{\omega} \psi$, appearance.)

\section{BATHYSAUROPS MALAYANUS, new species}

\section{Figure 6}

Depth 9 ; head $31 / 3$, width $21 / 8$. Snout 4 in head from snout tip; eye 4 , subequal with snout, greatly exceeds interorbital; maxillary reaches below hind eye edge, expansion $21 / 5$ in eye, length $13 / 4$ in head from snout tip; interorbital $5 \frac{1}{3}$, low, nearly level. Gill rakers $5+14$, lanceolate, which 2 in eye; gill filaments $7 / 8$ of gill rakers.

Scales (pockets) $48+$ in lateral line; 6 above, 6 below, 20 predorsal forward to occiput. Scales on chest, breast, and belly small. Scales simple, without striae; circuli fine, basal, about 21, obsolete apically.

D. I, 11 , I, third branched ray $12 / 3$ ? in total head length; adipose fin $2 \frac{1}{5}$ in eye; A. III, 7 , I, second branched ray $2 \frac{5}{5}$ in total head length; caudal $13 / 4$ ?, apparently well emarginate behind; least depth of caudal peduncle 5 ; pectoral $1 \frac{1}{4}$, rays II, 20 ; ventral rays I, 7 , fin $14 / 5$ in total head length.

Dark brown, blackish brown on head, breast, and belly. Inside gill openings blackish. Iris gray black, pupil pale brown. Fins brown to blackish, especially basally. 
Type.-U.S.N.M. no. 98888. D. 5656. Olang Point, N. $67^{\circ}$ W., 14.5 miles (lat. $3^{\circ} 17^{\prime} 40^{\prime \prime}$ S., long. $120^{\circ} 36^{\prime} 45^{\prime \prime}$ E.), Gulf of Boni, Celebes, Dutch East Indies. In 484 fathoms. December 19, 1909. Length $244 \mathrm{~mm}$.

Known only from the type.

(Named for Malaya.)

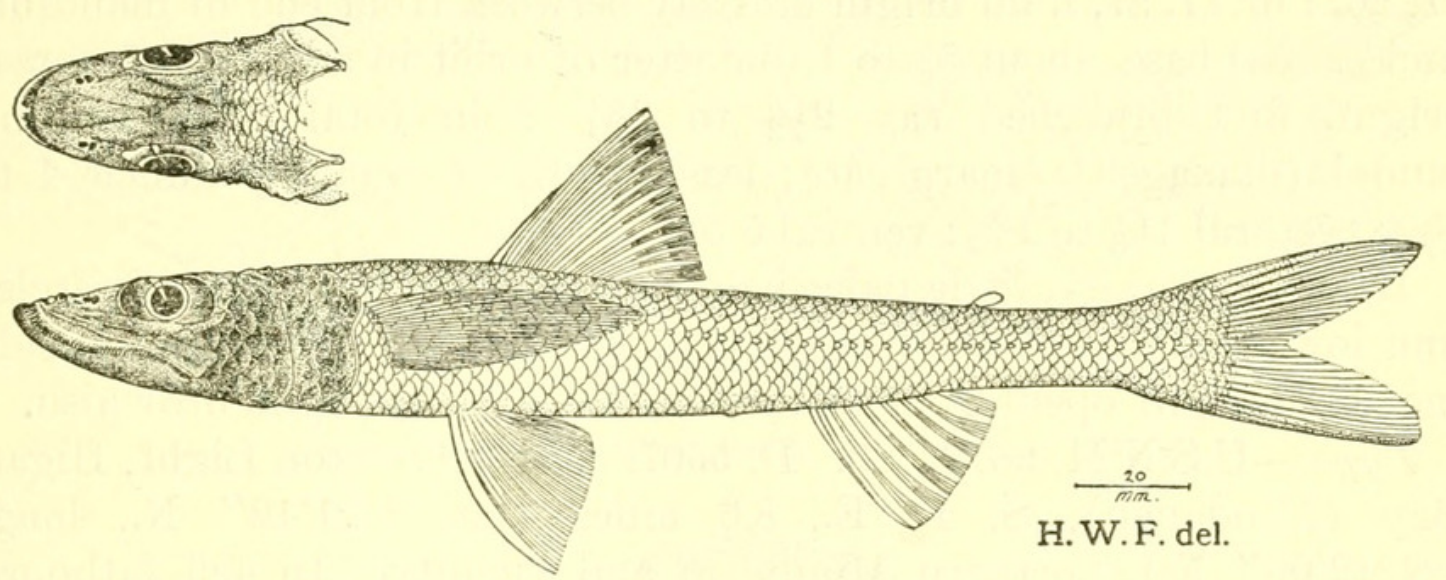

Figure 6.-Bathysaurops malayanus, new genus, new species. Type.

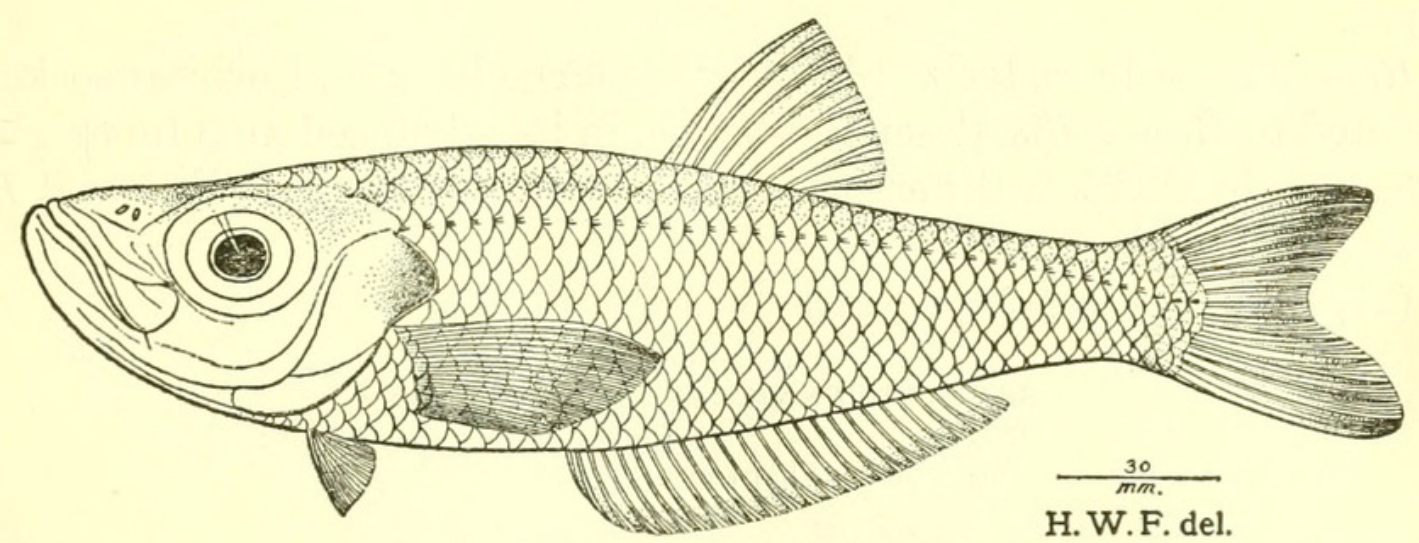

Figure 7.-Bathyclupea megaceps, new species. Type.

\section{Family BATHYCLUPEIDAE}

\section{Genus BATHYCLUPEA Alcock}

BATHYCLUPEA MEGACEPS, new species

\section{Figure 7}

Depth $34 / 5$ to $4 \frac{1}{4}$; head $2 \frac{1}{2}$ to $24 / 5$, width $22 / 5$ to $21 / 2$. Snout to orbit $32 / 3$ to $33 / 4$ in head from snout tip; orbit $21 / 2$ to $22 / 3$, greatly exceeds snout or interorbital; eye 3 to $31 / 5$ in head; maxillary reaches $1 / 8$ to $1 / 6$ in orbit, length $21 / 4$ to $21 / 2$ in head from snout tip; teeth in villiform bands above, with outer series uniformly and slightly enlarged; lower teeth single row of small, uniform conic teeth; interorbital $5 \frac{1}{4}$ to $57 / 8$, low, nearly level. Gill rakers $3+13$, lanceolate, 3 in orbit; gill filaments $4 / 5$ of gill rakers. 
Scales 35 in lateral line to caudal base and 3 more on latter; 3 above, 9 below, 15 predorsal forward to occiput close behind hind eye edge. Scales very thin, caducous, most all fallen except few in lateral line.

D. I, 8, I, fin origin midway between hind eye edge or pupil and caudal base, first branched ray $22 / 5$ ? to $21 / 2$ in total head length; A. II, 26, I or II, 27, I, fin origin midway between front end of mandible and caudal base, about $7 / 8$ to 1 diameter of orbit in advance of dorsal origin, first branched ray $2 \frac{1}{2}$ to $33 / 4$ ? in total head length; caudal (damaged) emarginate; least depth of caudal peduncle 4 to $43 / 4$; pectoral $1 \frac{1}{3}$ to $1 \frac{2}{5}$; ventral 5 to 6 .

Brown generally, little paler below or on under surfaces. Opercles and lower surface of head neutral black. Iris silvery white. Inside mouth and gill opening blackish brown. Fins all light brownish.

Type.-U.S.N.M. no. 93323. D. 5507. Camp Overton Light, Iligan Bay (Mindanao), S. $1^{\circ}$ E., 8.6 miles (lat. $8^{\circ} 21^{\prime} 12^{\prime \prime}$ N., long. $124^{\circ} 12^{\prime} 06^{\prime \prime}$ E.), northern Mindanao and vicinity. In 425 fathoms. August 4, 1909. Length $238 \mathrm{~mm}$, caudal tips broken. Also 2 paratypes.

Remarks.-Characterized by its very large head and orbital socket. Related to $B$. gracilis, described below, in its advanced anal fin origin, a feature in which it differs at once from $B$. malayana Weber and $B$. hoskynii Alcock.

( $\mu \dot{\epsilon} \gamma \breve{a} s$, great $+\kappa \epsilon \phi \breve{a} \lambda \dot{\eta}^{\prime}$, head.)

\section{BATHYCLUPEA GRACILIS, new species}

Figure 8

Depth $33 / 4$ to 4 ; head 3 to $31 / 8$, width $21 / 8$ to 3 . Snout 3 to 4 in head from snout tip; eye $23 / 4$ to 3 , greater than snout in young to subequal with age, greater than interorbital; maxillary reaches to or $1 / 5$ in eye, length $21 / 4$ to $21 / 3$ in head from snout tip; interorbital $4 \frac{1}{2}$ to $5 \frac{1}{4}$, low, level. Gill rakers $2+13$, lanceolate, 2 in eye; gill filaments $2 \%$ of gill rakers; 4 more asperous rudimentary gill rakers above and 3 below.

Scales 35 or 36 in lateral line to caudal base and 3 more on latter; 3 above, 8 or 9 below, 14 or 15 predorsal forward opposite hind eye edge. Scales caducous, very thin, most all fallen. Scales with 78 to 80 complete circuli.

D. I, $8, \mathrm{I}$ or I, 9 , I, fin origin 1 to $13 / 5$ times eye behind anal origin, first ray $13 / 4$ to 2 in total head length; A. II, 23 , I to II, 26 , I, first branched ray $22 \%$ to 3 ; caudal $11 / 2$ to $13 / 4$, forked; least depth of caudal peduncle $31 / 5$ to $34 / 5$; pectoral $11 / 8$ to $1 \frac{1}{6}$, rays I, 26 ; ventral rays $I$, 5 , fin 3 to $5 \frac{1}{8}$ in total head. 
Brown, with silvery to gray tints below. Iris silvery white. Lower side of head silvery white. Fins pale uniform brownish white. Inside gill opening blackish.
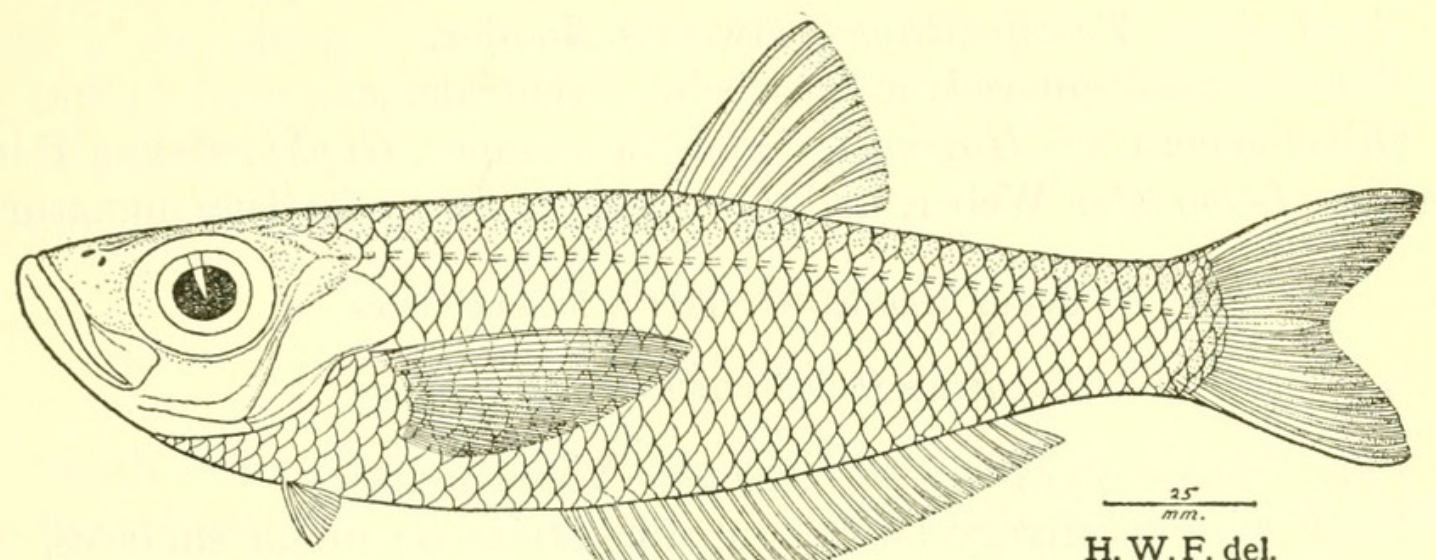

H. W. F. del.

Figure 8.-Bathyclupea gracilis, new species. Type.

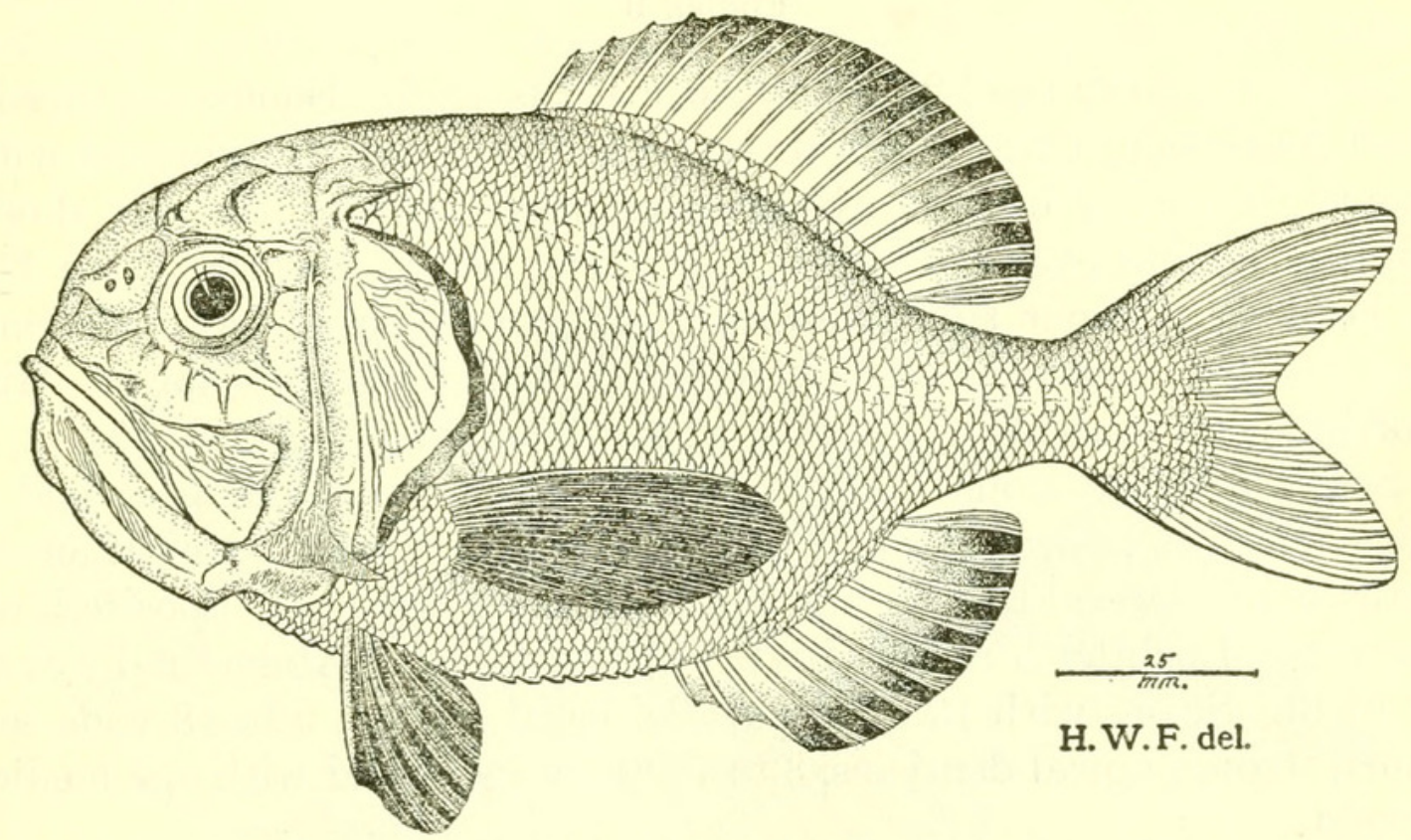

Figdre 9.-Hoplostethus melanopterus, new species. Type.

Type-U.S.N.M. no. 93320. D. 5622. Makyan Island (NE.), N. $66^{\circ}$ W., 4.1 miles (lat. $0^{\circ} 19^{\prime} 20^{\prime \prime}$ N., long. $127^{\circ} 28^{\prime} 30^{\prime \prime}$ E.). In 275 fathoms. November 29, 1909. Length $230 \mathrm{~mm}$. Also 20 paratypes.

Remarks.-Differs from $B$. megaceps in its shorter and smaller head, though with dorsal in similar position. The eye, while larger than usual, is smaller than in $B$. megaceps.

(gracilis, slender.) 


\section{Family TRACHICHTHYIDAE}

\section{TRACHICHTHYinAE, new subfamily}

Type genus, Trachichthys Shaw and Nodder.

Vent normally placed, at least behind ventrals.

Other genera are Hopolostethus Valenciennes, Gephyroberyx Boulenger, Leiogaster Weber, and Korsogaster Parr, the last immature.

\section{Genus HOPLOSTETHUS Valenciennes}

\section{Subgenus Hoplostethus Valenciennes}

Type.-Hoplostethus mediterraneus Valenciennes.

Body without silvery lateral tubelike striae on under surfaces.

\section{HOPLOSTETHUS MELANOPTERUS, new species}

Figure 9

Depth $17 / 8$ to 2 ; head $2 \frac{1}{3}$ to $2 \frac{1}{2}$, width 2 to $2 \frac{1}{10}$. Snout, $37 / 8$ to 4 in head from snout tip; eye $33 / 4$ to $4 \frac{1}{8}$, slightly greater to subequal with snout, $1 \frac{1}{8}$ to $1 \frac{1}{4}$ in interorbital ; maxillary extends obliquely down slightly behind eye, expansion $1 \frac{1}{5}$ to $1 \frac{1}{3}$ in eye, length $1 \frac{1}{4}$ to $1 \frac{1}{2}$ in head from snout tip; interorbital $31 / 5$ to $31 \frac{1}{3}$, well elevated, convex; nasalia minute, close set, directed downward anteriorly. Gill rakers $7+16$, lanceolate, $1 \frac{1}{4}$ in eye; gill filaments $2 / 5$ gill rakers.

Scales 65 close along and above lateral line to caudal base and 4 more on latter; pores 27 or 28 in lateral line to caudal base; 12 or 13 scales above lateral line, 27 below, 26 predorsal forward opposite hind eye edge, 4 behind hind maxillary edge on cheek. Abdominal serrae 11 to 13 . Scales with 15 to 18 parallel basal circuli; 9 to 18 wide set, short, strong, apical denticles, 3 to 7 transversely and with age medial largest.

D. IV or $\mathrm{V}, 13$, I or 14 , I, last spine 3 to $3 \frac{1}{8}$ in total head length, third ray $2 \frac{1}{4}$ to $2 \frac{1}{3} ;$ A. III, 10 , I, third spine $34 / 5$ to $4 \frac{1}{8}$, second ray $21 / 2$ ? to $27 / 8$ ?; caudal $1 \frac{1}{10}$, well forked; least depth of caudal peduncle $37 / 8$ to 4 ; pectoral $1 \frac{1}{8}$ to $1 \frac{1}{6}$; ventral $1 \frac{4}{5}$ to 2 .

Brown, with coppery sheen, especially over squamous areas. Iris pale gray to coppery. Inside gill opening dusky. Vertical fins very pale or light brown. Paired fins dark or blackish brown.

Type.-U.S.N.M. no. 93329. D. 5373. Tayabas Light (outer), N. $20^{\circ}$ E., 15 miles (lat. $13^{\circ} 40^{\prime}$ N., long. $121^{\circ} 31^{\prime} 10^{\prime \prime}$ E.), Marinduque Island and vicinity. In 338 fathoms. March 2, 1909. Length 170 mm. Also 46 paratypes.

Known by its dark to blackish paired fins.

( $\mu \epsilon^{\prime} \lambda a^{\prime} s$, black $+\pi \tau \epsilon \rho o ́ \nu$, fin.) 


\section{Aulohoplostethus, new subgenus}

Type.-Hoplostethus metallicus, new species.

Silvery lateral tubelike striate areas on chest, breast, prepectoral region, and along abdominal edge.

Differs from subgenus Hoplostethus in the silvery lateral tubelike striate areas.

(aủ入ós, tube +Hoplostethus.)

\section{HOPLOSTETHUS METALLICUS, new species}

Figure 10

Depth $1 \frac{1}{10}$ to 2 ; head $2 \frac{1}{3}$ to $2 \% 5$, width $19 / 10$ to $2 \frac{1}{5}$. Snout 4 to $4 \frac{1}{2}$ in head from snout tip; eye 3 to $3 \frac{1}{3}$, greater than snout, equals interorbital ; maxillary oblique, reaches opposite hind eye edge; expansion $1 \frac{1}{5}$ to $1 \frac{1 / 4}{4}$ in eye, length $1 \frac{2}{5}$ in head from snout tip; teeth in villiform bands in jaws and on palatines, none on vomer; interorbital $31 / 3$ to $32 / 5$, convex; nasalia minute, close set, directed downward. Gill rakers $8+16$, lanceolate, twice gill filaments or $1 \frac{1}{2}$ in eye.

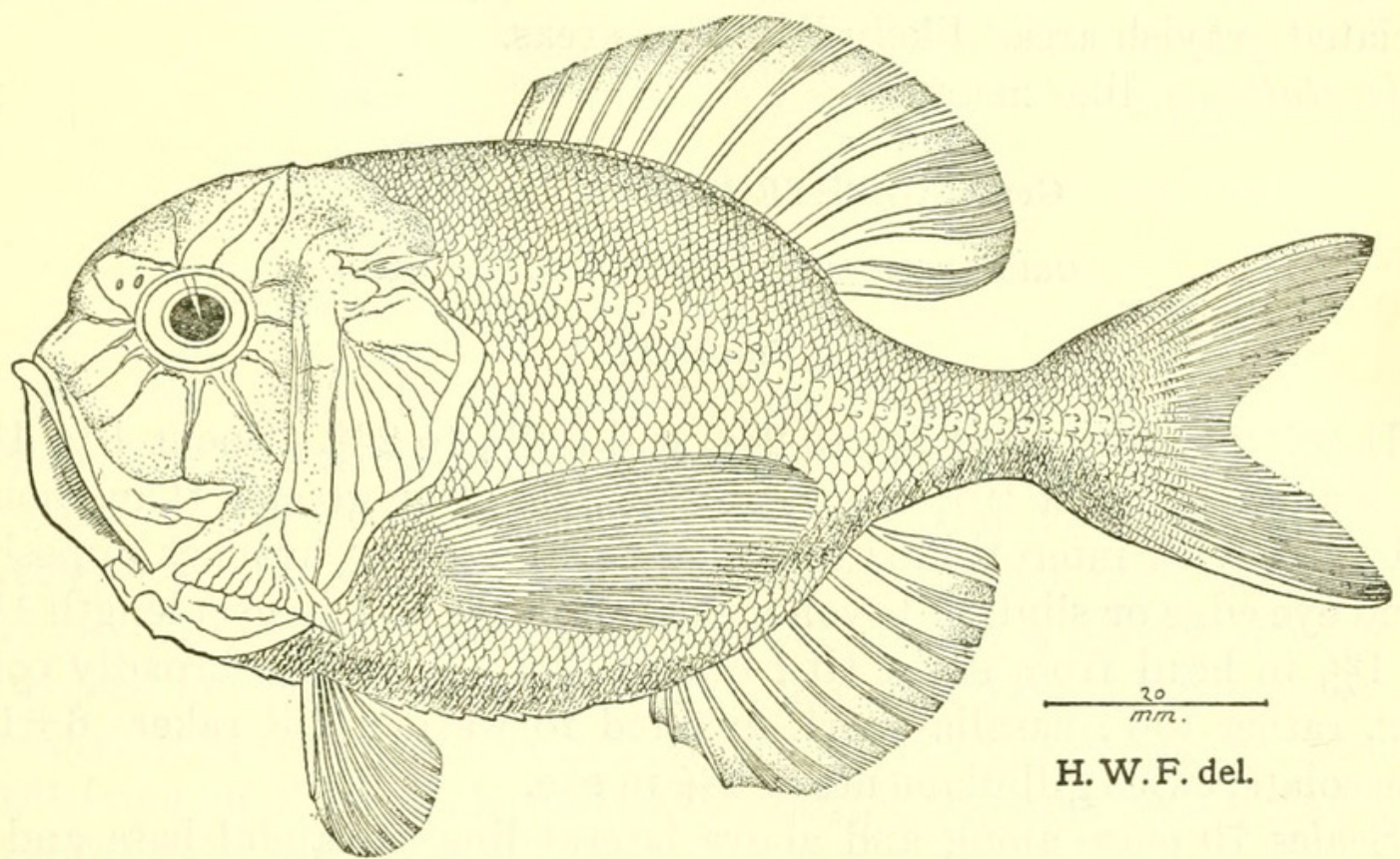

Figure 10.-Hoplostethus metallicus, new species. Type.

Scales 70 close along above lateral line to caudal base and 4 more on latter; pores $29 ; 13$ scales above, 22 below, 28 predorsal forward nearly opposite hind eye edge, 6 behind maxillary expansion. Abdominal serrae 5 or 6 . Chest, breast, prepectoral area, narrow strip from above ventral base along each side of abdominal or postventral serrae to anal fin origin, silvery gray area, with very fine parallel closeset dark lines whole extent; similar area begins well above anal origin on lower side of tail and extends back along lower or under surface 
of caudal peduncle to lower rudimentary caudal rays. Similar silvery areas along each outer face of mandible, on chin and walls of isthmus. Scales with 10 to 18 basal parallel striae; 8 or 9 small, short, apical denticles, with 4 or 5 transverse series.

D. V, 13 , I, fifth spine $23 / 4$ to $31 / 5$ in total head length, second branched ray $2 \frac{1}{5}$ to $2 \frac{1}{2}$; A. III, 8 , I or III, 9 , I, third spine $31 / 8$ to $37 / 8$, first branched ray $2 \frac{1}{2}$ ? to 3 ; caudal 1 to $1 \frac{1}{10}$, deeply forked, lobes slender, pointed; least depth of caudal peduncle $4 \frac{1}{2}$ to $44 / 5$; pectoral $1 \frac{1}{10}$ to $11 / 5$; ventral $13 / 5$ to 2 .

Dark gray-brown, with shining metallic dusky sheen. Iris grayish to dusky or silvery. Inside gill opening dusky to blackish. Fins pale to whitish, caudal lobes medially and upper pectoral rays dusky.

Type.-U.S.N.M. no. 93344. D. 5189. Pescador Island, N. $72^{\circ}$ E., 3.3 miles (lat. $9^{\circ} 56^{\prime} 30^{\prime \prime}$ N., long. $123^{\circ} 15^{\prime}$ E.), Tanon Strait, east coast of Negros, Philippine Islands. In 300 fathoms. April 1, 1908. Length $123 \mathrm{~mm}$. Also a series of Philippine paratypes.

Remarks.-Differs from related species in the delicate narrow osseous compartments enclosing the cavernous areas of the head, dark coloration, few abdominal serratures and peculiar metallic finely striated grayish areas, likely luminous areas.

(metallicus, like metal.)

\section{Genus GEPHYROBERYX Boulenger}

GEPHYROBERYX PHILIPPINUS, new species

Figure 11

Depth 2 to $2 \frac{1}{8}$; head $2 \frac{1}{3}$ to $22 / 5$, width $2 \frac{1}{4}$ to $23 / 5$. Snout 4 to $4 \frac{1}{2}$ in head from snout tip; eye $31 / 8$ to 4 , equal to or greater than snout, subequal with interorbital; maxillary very oblique, reaches opposite hind eye edge or slightly beyond, expansion $12 / 5$ to 3 in eye, length $11 / 2$ to $12 / 3$ in head from snout tip; interorbital $3 \%$ to $37 / 8$, broadly convex, rather low; nasalia short, directed forward. Gill rakers $6+15$, lanceolate, twice gill filaments or $12 / 5$ in eye.

Scales 70 close along and above lateral line to caudal base and 4 or 5 more on latter; pores 27 in lateral line to caudal base and 3 more on latter; 18 above, 19 below, predorsal $20 ; 6$ rows behind hind expansion of maxillary. Abdominal serrae 8 to 10 . Scales with 13 or 14 basal parallel striae; 22 or 23 slender pointed apical denticles, 3 or 4 rows irregularly transverse.

D. VIII, 13 , I or 14 , I, fourth spine $27 / 8$ to 3 in total head length, second branched ray 2 to $21 / 8$; A. III, 10 , I or 11 , I, third spine $37 / 8$ to 4 , second branched ray $21 / 4$ to $21 / 3$; caudal $1 \frac{1}{4}$ to $1 \frac{1}{3}$, forked ; least depth of caudal peduncle 5 to $51 / 5$; pectoral $13 / 5$ to $12 / 3$; ventral $14 / 5$ to 2 . 
Back brown, lower surfaces slightly paler and with silvery white sheen. Iris pale or silvery white. Fins all pale or with yellow to dull orange tints.

Type-U.S.N.M. no. 93345. D. 5516. Point Tagolo Light (Mindanao), S. $80^{\circ}$ W., 9.7 miles (lat. $8^{\circ} 46^{\prime}$ N., long. $123^{\circ} 32^{\prime} 30^{\prime \prime}$ E.), northern Mindanao and vicinity, Philippine Islands. In 175 fathoms. August 9, 1909. Length $155 \mathrm{~mm}$. Also a series of Philippine examples, paratypes.

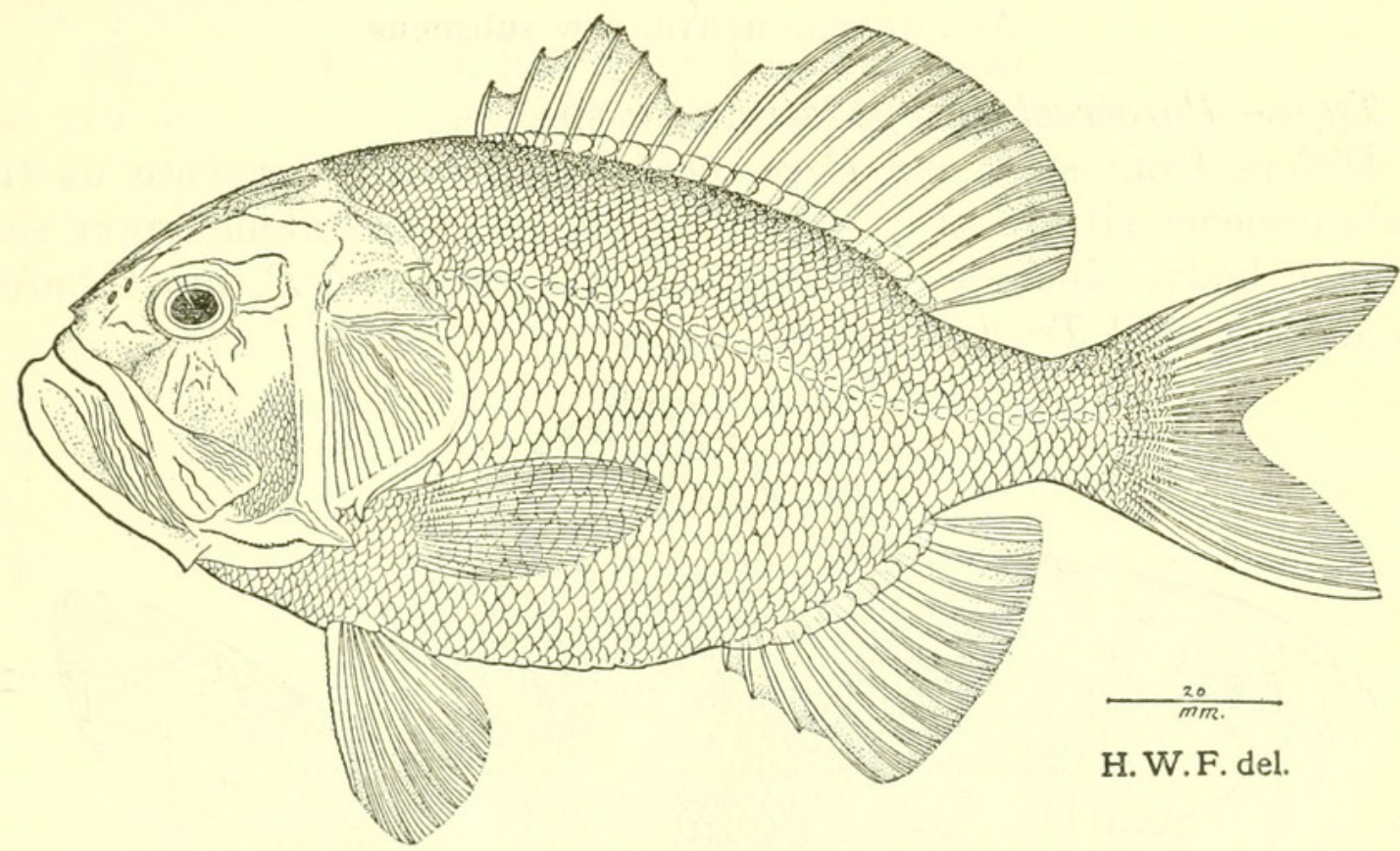

Figure 11.-Gephyroberyx philippinus, new species. Type.

Remarks.-East Indies, Philippines. Related to Gephyroberyx japonicus (Steindachner and Döderlein) from Japan but differing in the few (8-10) abdominal scutes, always about 14 in the Japanese species. It also approaches $G$. darwini (Johnson) from Madeira in the few (10) abdominal scutes, but that species is described with 12 branched anal rays, while my species has but 10 or 11 . Noreover $G$. darwini is said to have depth 21/3. Trachichthys darwini of Alcock, 1899, from off Trincomale, and of Barnard, 1925, from Natal, may also be confused with the present species.

(Named for the Philippines.)

\section{Subfamily ParatrachichthyinaE}

Vent more advanced, close behind ventral bases. Abdominal serrae behind vent. 


\section{Genus PARATRACHICHTHYS Waite}

\section{ANALYSIS OF SPECIES}

$a^{1}$. Aulotrachichthys, new subgenus. Subcutaneous silvery-gray

striated tubes and areas along lower surface of body.

$b^{1}$. Depth $22 / 7$ to $23 / 5$; gill rakers $6+10$ latus.

$b^{2}$. Depth $2 \% 3$; gill rakers $6+15$ prosthemius. $a^{2}$. Paratrachichthys. No subcutaneous tubes or areas along lower surface of body; depth $2 \%$; gill rakers $9+18_{-}$ traillii.

\section{Aulotrachichthys, new subgenus}

Type.-Paratrachichthys latus, new species.

Differs from subgenus Paratrachichthys in the presence of the subcutaneous silvery-gray striated tubes and areas along lower surface of body. Includes Paratrachichthys latus and P. prosthemius.

(aủiós, tube+Trachichthys.)

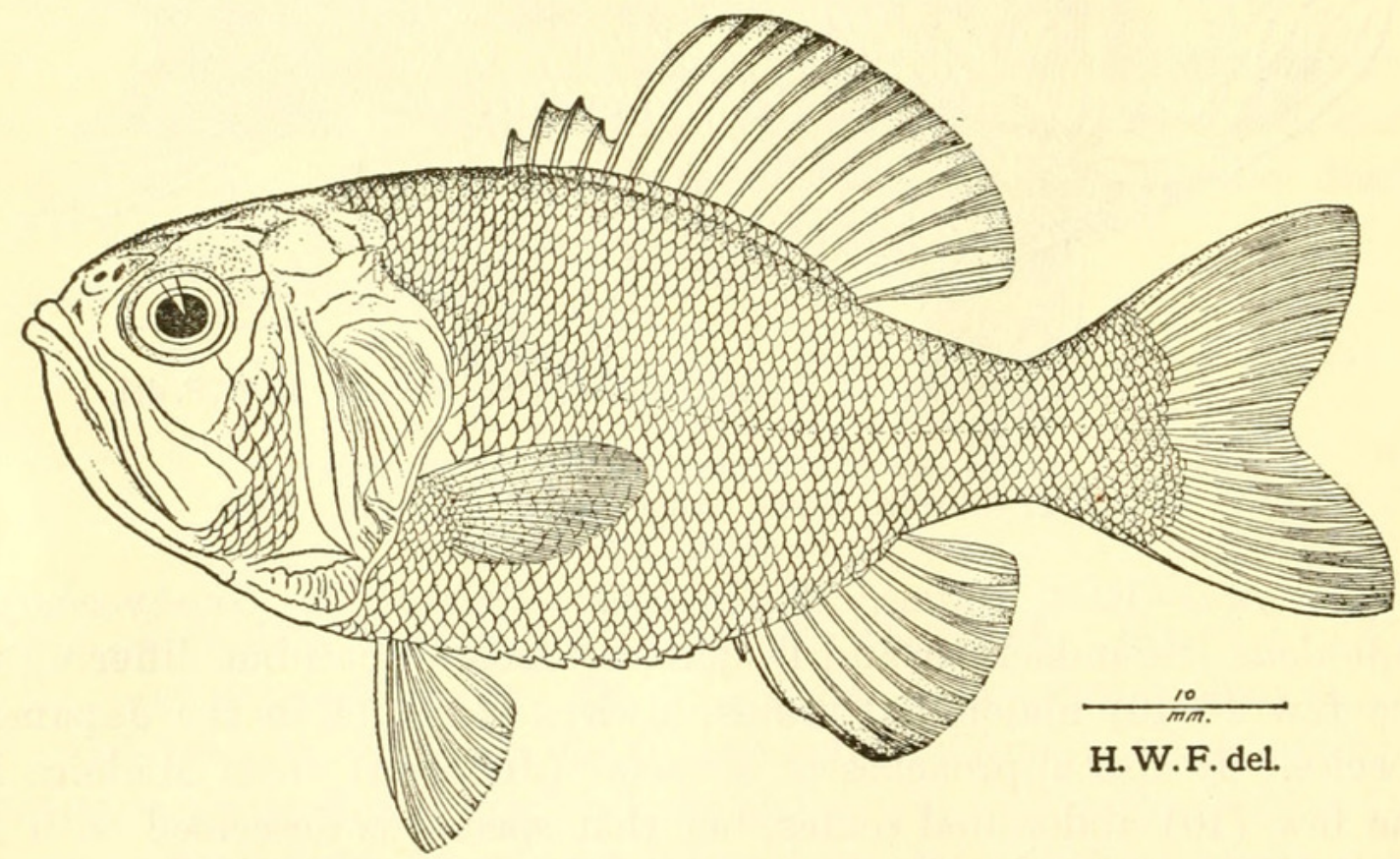

Figure 12.-Paratrachichthys latus, new species. Type.

PARATRACHICHTHYS LATUS, new species

Figure 12

Depth $22 / 7$ to $23 / 5$; head $2 \frac{2}{5}$ to $33 / 5$, width 2 to $21 / 6$. Snout $42 / 3$ to $47 / 8$ in head from snout tip; eye $3 \frac{1}{2}$ to $3 \frac{3}{4}$, greater than snout or interorbital; maxillary greatly inclined, reaches slightly beyond hind eye edge, expansion $11 / 8$ to $11 / 3$ in eye, length $12 / 5$ in head from snout tip; bands of villiform teeth in jaws and on palatines, none on vomer; interorbital $37 / 8$ to $4 \frac{1}{2}$ in head from snout tip, low, broadly convex. Gill rakers $6+10$, lanceolate, twice gill filaments or $11 / 4$ in eye. 
Scales 58 in medial or lateral axial series; lateral line imperfectly defined, seldom complete; 27 scales transversely at anal origin; 23 predorsal forward opposite hind eye edge. Cheek scaled largely posteriorly, 6 rows behind maxillary expansion. Abdominal scutes 7 to 9. Scales with 12 to 16 basal circuli; apical denticles 10 or 11 , scattered, 5 transversely, rather large simple points. Chin, walls of isthmus, chest, breast, region around vent and band along abdominal scutes and above anal base of silvery-gray striated pigment, also space before pectoral base.

D. IV, I or III, 15 , I, last spine 4 to 5 in total head length, fifth ray 2 to $2 \frac{1}{s}$; A. II, 9 , I, second spine $52 / 5$, second ray $2 \frac{1}{5}$ to $23 / 4$; caudal $11 / 5$ to $12 / 5$, deeply forked; least depth of caudal peduncle 3 to $31 / 4$; pectoral $13 / 5$ to $14 / 5$; ventral $14 / 5$ to 2 .

Body brown generally, slightly lighter or with more gray tinge below, also shining reflections of silver gray. Iris silver-gray. Inside gill opening silver-gray. Fins pale to whitish.

Type.-U.S.N.M. no. 93346. (2507.) Philippines. Length $70 \mathrm{~mm}$. Also a series of Philippine examples, paratypes.

Remarks.-Philippine Islands. Related to Paratrachichthys prosthemius especially in its gray subcutaneous tubular striated areas and scutes. It differs, however, in fin formula, gill rakers, proportions, etc. Bathymetrical range 90 to 395 fathoms.

(latus, broad.)

\section{Family SYNGNATHIDAE}

\section{Genus DUNCKEROCAMPUS Whitley}

\section{DUNCKEROCAMPUS PESSULIFERUS, new species}

\section{Figure 13}

Depth $201 / 3,17$ to vent; head $3 \frac{1}{6}, 34 / 5$ to caudal base, width 7 in its length. Snout $12 \%$ in head from snout tip; eye 9, 61/4 in snout, greatly exceeds interorbital; maxillary $3 / 5$ of eye; interorbital $12 / 5$, concave. Opercle with imperfect or feeble keel anteriorly, oblique, extends $2 / 3$ of bone.

Rings $19+20$, caudal section $4 / 5$ of trunk. Upper trunk keel discontinuous with upper caudal keel, both overlapping whole length of dorsal fin; lower trunk keel discontinuous with lower caudal keel; median lateral trunk keel continuous with lower caudal keel; median ventral trunk keel distinct, discontinuous at vent. Snout with upper ridges, orbital ridges, and mandibular ridges serrate. Each ridge of body with spine posteriorly, distinct and protruding.

D. 26 , on $3+4$ rings, fin height $11 / 5$ in eye; A. 2 ?, fin length 2 in eye; caudal 3 in total head length, ends in median point behind; pectoral rays 19 , fin length equals eye. 
Light brown, nearly uniform. Just before interorbital 3 dark brown transverse bars, 1 across interorbital, and 6 on postocular region of head; middle of each trunk ring with dark brown transverse bar, also one at each articulation; for extent of dorsal fin only dark transverse brown bar at each articulation; on tail otherwise rings marked like trunk. Iris slate. Fins uniformly brown.

Type-U.S.N.M. no. 93501 . D. 5146 . Sulade Island (E.), N. $18^{\circ}$ W., 3.4 miles (lat. $5^{\circ} 46^{\prime} 40^{\prime \prime}$ N., long. $120^{\circ} 48^{\prime} 50^{\prime \prime}$ E.), Sulu Archipelago, vicinity of Siasi. In 24 fathoms. February 16, 1908. Length $110 \mathrm{~mm}$.

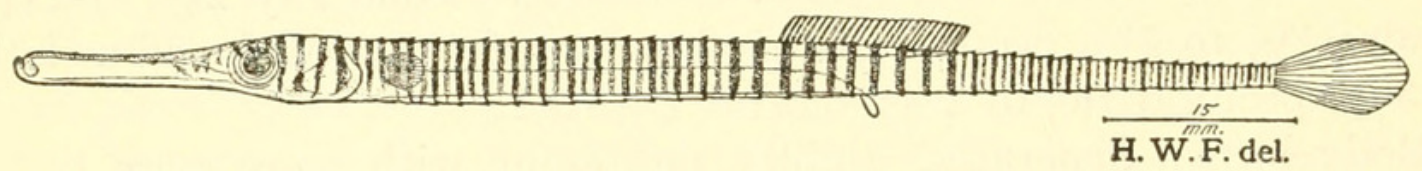

Figure 13.-Dunckerocampus pessuliferus, new species. Type.

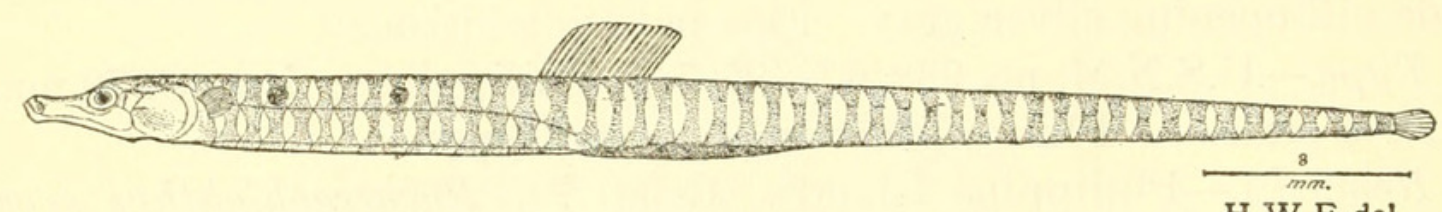

Figdre 14.-Syngnathus micronotopterus, new species. Type.

Remarks.-Related to Dunckerocampus dactyliphorus (Bleeker), of which I have 4 Philippine examples, ranging from smaller to larger than the species here described. As shown by Weber and Beaufort's figure, the dark bars are alternately present on the various rings. Also the snout is with dark transverse bars and the subdorsal rings only $1+3$ or 4 .

(pessutum, little bar +fero, to bear; with reference to coloration.)

\section{Genus SYNGNATHUS Linnaeus}

\section{SYNGNATHUS MICRONOTOPTERUS, new species}

Figure 14

Depth $162 / 3$ to $172 / 3$; head 7 to $81 / 8$, width $23 / 5$ to $24 / 5$. Snout $21 / 2$ to $24 / 5$ in head; eye $47 / 8$ to $52 / 5,17 / 8$ in snout, greatly exceeds interorbital; interorbital 2 in eye; opercular keel about over first or basal half, radiating striae very fine minute, close set.

Rings 15 to $16+28$ to 30 ; rings transversely striated. Upper trunk keel reaches first or second caudal ring, discontinuous with upper caudal keel, which begins on upper part of last trunk ring; median lateral trunk keel deflected posteriorly and continuous with lower caudal keel; lower trunk keel subcontinuous or discontinuous with lower caudal keel. Brood pouch on 11 caudal keels. 
D. 16 to 18 , on 1 trunk and 3 caudal rings, fin height $17 / 8$ to 2 in total head; A. minute; caudal $4 \frac{1}{5}$; pectoral $4 \frac{1}{3}$ to 5 , rays 10 .

Male largely uniform brown, scarcely paler below. Above median lateral keel of trunk 3 blackish equidistant blotches. Brood pouch neutral black. Fins all brownish.

Female light brown, lower surface little paler, though more or less mottled. Eleven blackish-brown transverse bars on back, each followed by small, gray-white, rounded, well-contrasted spot. Three dark-brown bars across lower side of snout, one obliquely back from lower eye edge and another broadly from lower postocular. Dark brown band from upper postocular widens and extends ill defined toward occiput. Iris dark gray. At junction of each ring on upper and lower body edges dark brown spot. Fins pale, caudal with dark transverse bar.

Type.-U.S.N.M. no. 94082. Canimo Island near Daet Point, Luzon, Philippine Islands. June 15, 1909. Length $56 \mathrm{~mm}$.

Also a series of paratypes from the Philippines and the East Indies.

Remarks.-East Indies, Philippines. This species is characterized by its short opercular keel only developed anteriorly, few dorsal rays, and its variegated coloration. It resembles Halicampus koilomatodon (Bleeker) but is without the spines and strongly keeled rough rings of that species.

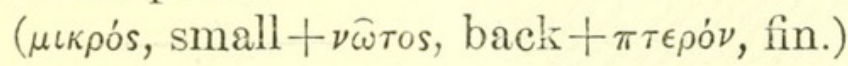

\section{Genus ICHTHYOCAMPUS Kaup}

\section{ICHTHYOCAMPUS PHILIPPINUS, new species}

Depth $171 / 3$; head 7 , width $31 / 2$. Snout $21 / 3$ in head from snout tip; eye $51 / 5,21 / 3$ in snout, greatly exceeds interorbital; low median keel on snout above to interorbital; occipital-nuchal keel short, low, not on first trunk ring; narrow interorbital half of eye, shallowly concave; opercle with low short basal keel anteriorly, with many fine radiating striae.

Rings $17+32$; with very fine, minute transverse striae; keels low, smooth. Upper trunk and caudal keels continuous; median lateral trunk keel not extended on first caudal keel; lower trunk and caudal keels continuous; median ventral trunk keel distinct to vent.

D. 17 , on 1 trunk and 4 caudal rings, base not elevated, height $14 / 5$ in eye; A. $1 \frac{1}{3}$ in eye; caudal $4 \frac{1}{2}$ in head; pectoral $53 / 5$, rays 12 ?.

Brown, more or less uniform, head little paler. Iris slate. Fins all pale. 
Type.-U.S.N.M. no. 94080. D. 5160. Tinakta Island (N.), S. $72^{\circ}$ W., 2.75 miles (lat. $5^{\circ} 12^{\prime} 40^{\prime \prime}$ N., long. $119^{\circ} 55^{\prime} 10^{\prime \prime}$ E.), Sulu Archipelago. In 12 fathoms. February 22, 1908. Length $55 \mathrm{~mm}$.

Remarks.-Closely related to Ichthyocampus erythraeus Gilbert, but differs in its shorter and more robust snout, eyes directed more or less superiorly, median lateral trunk keel not extending on the first caudal ring and fewer dorsal rays.

(Named for the Philippines.)

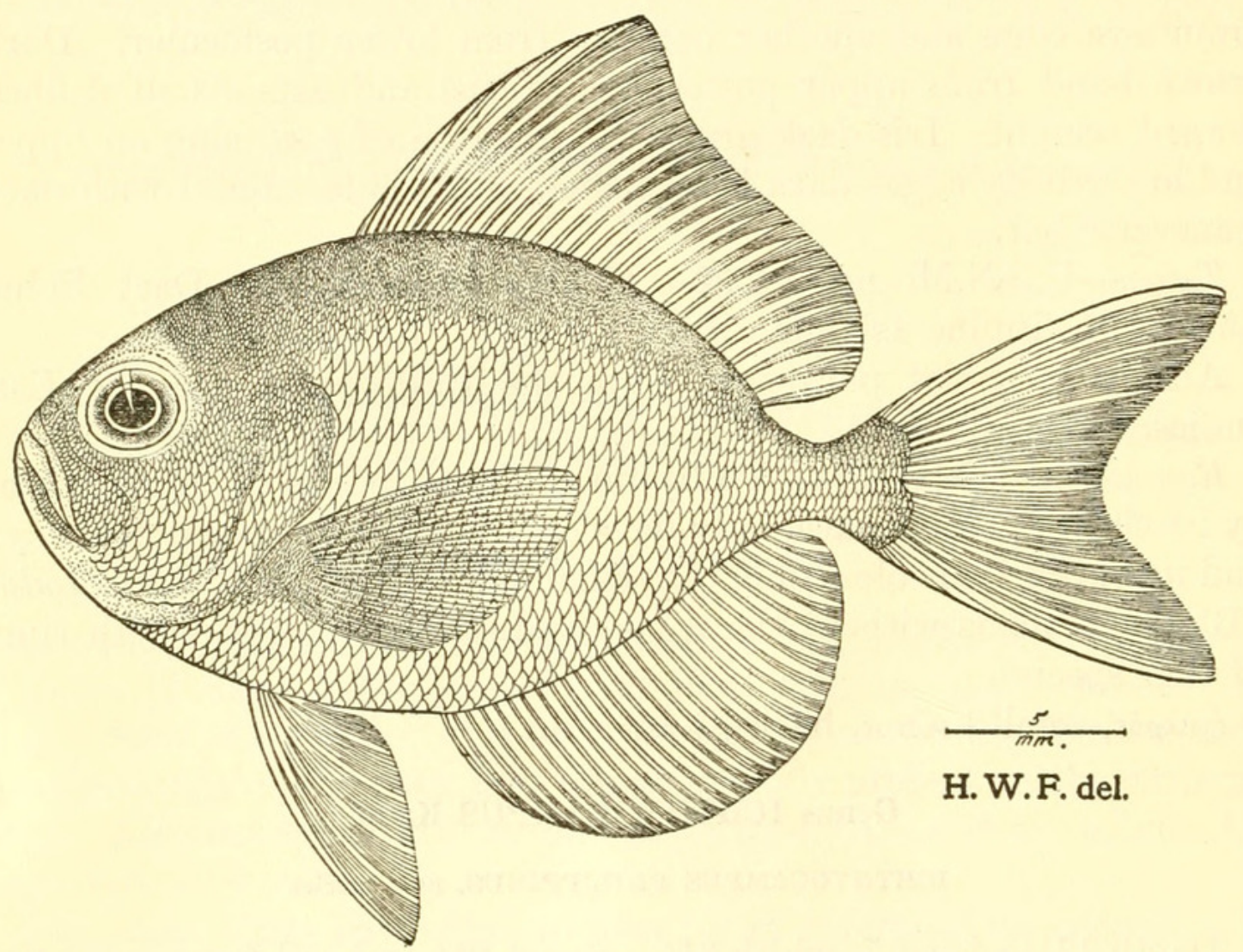

Figure 15.-Brama leucotaenia, new species. Type.

Family BRAMIDAE

Genus BRAMA Schneider

BRAMA LEUCOTAENIA, new species

Figure 15

Depth $13 / 4$; head $23 / 4$, width $13 / 4$. Snout $41 / 4$ in head from snout tip; eye $21 / 2$, twice snout, little greater than interorbital; maxillary reaches $1 / 3$ in eye, expansion $1 / 2$ of eye, length 2 in head from snout tip; interorbital $2 \frac{1}{2}$, low, convex; preopercle edge with rather large serrae. Gill rakers $4+10$, lanceolate, $1 / 3$ of gill filaments, which $13 / 4$ in eye.

Scales 55 in lateral line to caudal base; 10 above, 15 below, 23 predorsal forward opposite hind pupil edge; 10 below across cheek. 
Scales on middle of sides very narrowly imbricated, with median horizontal keel. Interorbital, snout, and mandible scaleless. Fins not scaly.

D. III, 26 , fin height anteriorly $1 \frac{1}{8} 8$ in total head; A. 27 , fin height $11 / 4$; least depth of caudal peduncle 4 ; pectoral 1 , rays I, 16 ; ventral I, 5 , fin $1 \frac{1}{8}$ in total head.

Brown on back, sides and below with dull brassy tint. Iris brownish. Fins all more or less brownish and dorsals with a longitudinal subbasal pale though distinctly evenly defined pale or light band its whole extent.

Type.-U.S.N.M. no. 98817. D. 5134. Balukbaluk Island (N.) S. $59^{\circ}$ W., 6.25 miles (lat. $6^{\circ} 44^{\prime} 45^{\prime \prime}$ N., long. $121^{\circ} 48^{\prime}$ E.), Sulu Archipelago, near Basilan Island, Philippines. February 7, 1908. In 25 fathoms. Length $32 \mathrm{~mm}$.

Remarks.-Known only from the above described young specimen, which differs from Brama raii (Bloch) in the presence of the pale subbasal longitudinal band on the dorsals. Lütken figures slightly larger and smaller specimens (Spolia Atlantica, 1880, pl. 4, figs. 1, 2), though they have their fins uniformly colored. My drawing does not show the lower scales of the tail quite so contrasted in their convergence as seen on the type specimen.

( $\lambda \epsilon u \kappa o ́ s, ~ w h i t e+\tau a \iota v i a$, ribbon; with reference to the white band on the dorsal fin.)

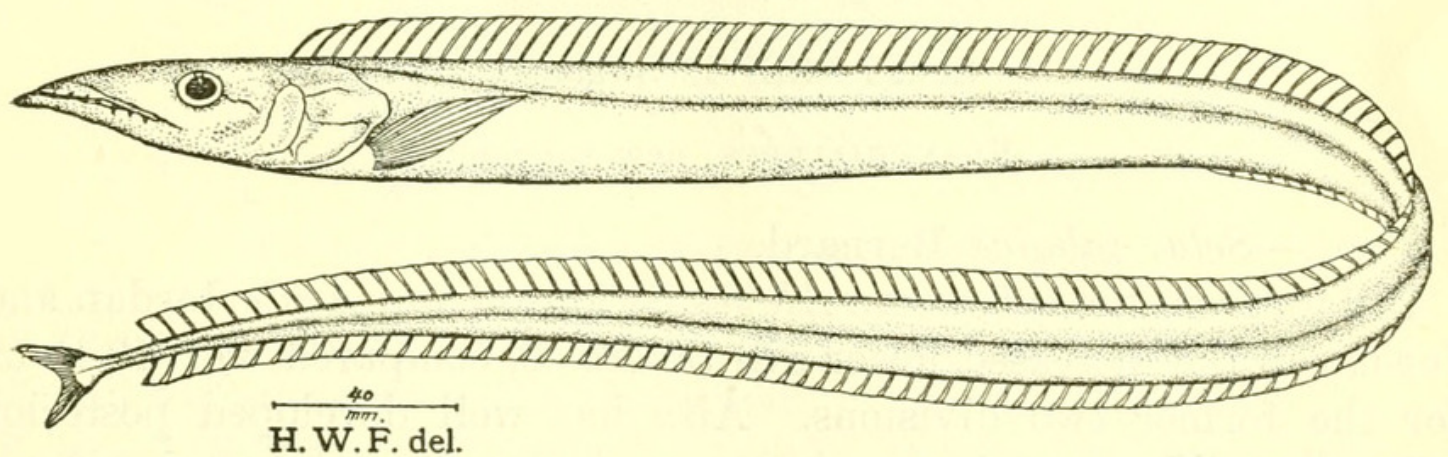

Figure 16.-Benthodesmus benjamini, new species. Type.

\section{Family LEPIDOPIDAE}

\section{Genus BENTHODESMUS Goode and Bean}

BENTHODESMUS BENJAMINI, new species

Figure 16

Depth 21 to $212 / 3$; head $62 / 3$ to $7 \frac{4}{5}$, width $5 \frac{1}{3}$ to 6 . Snout $2 \frac{1}{6}$ to $21 / 5$ in head from snout tip ; eye $64 / 5$ to $84 / 5,3$ to 4 in snout, $\frac{9}{10}$ in interorbital in young to greater than interorbital with age; maxillary 
reaches eye, expansion $1 \frac{1}{2}$ to 2 in eye, length $2 \frac{1}{5}$ to $22 / 5$ in head from snout tip; 4 large upper front canines, followed by 5 or 6 smaller wide set teeth each side; 8 or 9 wide set teeth each side below, first one of which well inclined back and not enlarged; row of small slender teeth on each palatine; interorbital $61 / 4$ to 9 , rather low, level. Gill rakers as $2+7$, low, short, feeble denticles, barely $1 / 4$ of gill filaments, which $13 / 4$ in eye.

No scales. Lateral line complete, axial along side of body.

D. 115 to 122 , fin height 7 in total head length; A. 74, lower than dorsal; caudal 6 to $61 / 4$ ? (damaged) ; least depth of caudal peduncle $21 / 2$ to 5 in eye; pectoral $22 / 5$ to 3 in head, rays 12 ; ventral small pair of rudimentary scalelike flaps opposite pectoral origin on median line of belly, about $1 / 3$ of eye.

Gray or leaden, where skin rubbed off brown. Iris gray. Inside mouth and gill opening blackish gray. Fins pale.

Type.-U.S.N.M. no. 98821. D. 5445. Atalaya Point, Batag Island, S. $56^{\circ}$ E., 5.3 miles (lat. $12^{\circ} 44^{\prime} 42^{\prime \prime}$ N., long. $124^{\circ} 59^{\prime} 50^{\prime \prime}$ E.), east coast of Luzon, Philippines. In 383 fathoms. June 3, 1909. Length $632 \mathrm{~mm}$. Also a series of 4 paratypes from deep water in the Philippines and East Indies.

(Named for Dr. Marcus Benjamin (1857-1932), efficient editor during many years of the publications of the United States National Museum.)

\section{Family CARANGIDAE}

\section{Genus ALEPES Swainson}

BRANCHIALEPES, new subgenus

\section{Type.-Selar tabutae Barnard.}

Differs from the subgenera Alepes Swainson and Atule Jordan and Jordan in the increased lower gill rakers 50, compared with 19 to 32 for the former two divisions. Also has well developed posterior adipose eyelids.

$(\beta \rho a ́ \gamma \chi \iota \nu$, gill + Alepes, with reference to the numerous lower gill rakers.)

\section{Genus URASPIS Bleeker}

URASPIS PECTORALIS, new species

\section{Figure 17}

Depth $2 \frac{1}{3}$; head $27 / 8$, width $21 / 8$. Snout $2 \frac{1}{8}$ in head from snout tip; eye $31 / 5,11 / 5$ in snout, $11 / 5$ in interorbital; orbit 3 , equals snout; maxillary reaches $1 / 8$ in eye, expansion 2 in eye, length $2 \frac{1}{3}$ in head from snout tip; teeth uniserial in jaws, absent from palate or tongue; 
interorbital 3, convexly elevated, with median ridge extending to dorsal. Gill rakers $4+13$, lanceolate, equal gill filaments, which $13 \%$ in eye.

Scales $52+36$ in lateral line, straight section $1 \frac{1}{8}$ in low arch; 20 above arch to soft dorsal orgin, 40 below. Breast and chest naked to pectoral base and behind ventral bases. Fins not scaly, only scaly sheaths at bases of soft dorsal and anal. Caudal base scaly. Very few scales on cheek, only few close to infraorbitals and about postocular. Scute, depth $33 / 4$ in eye.

D. VIII-I, 24, I, second spine $61 / 4$ in total head, first branched ray $2 \frac{1}{10} ; \mathrm{A}$. II-I, 20 , I, first branched ray $2 \frac{1}{2}$; least depth of caudal peduncle $61 / 2$; caudal $11 / 5$ ?, forked; ventral $23 / 4$, reaches $14 / 5$ to anal; pectoral $24 / 5$ in fish without caudal, rays II, 21 , reaches $1 / 7$ in straight section of lateral line.

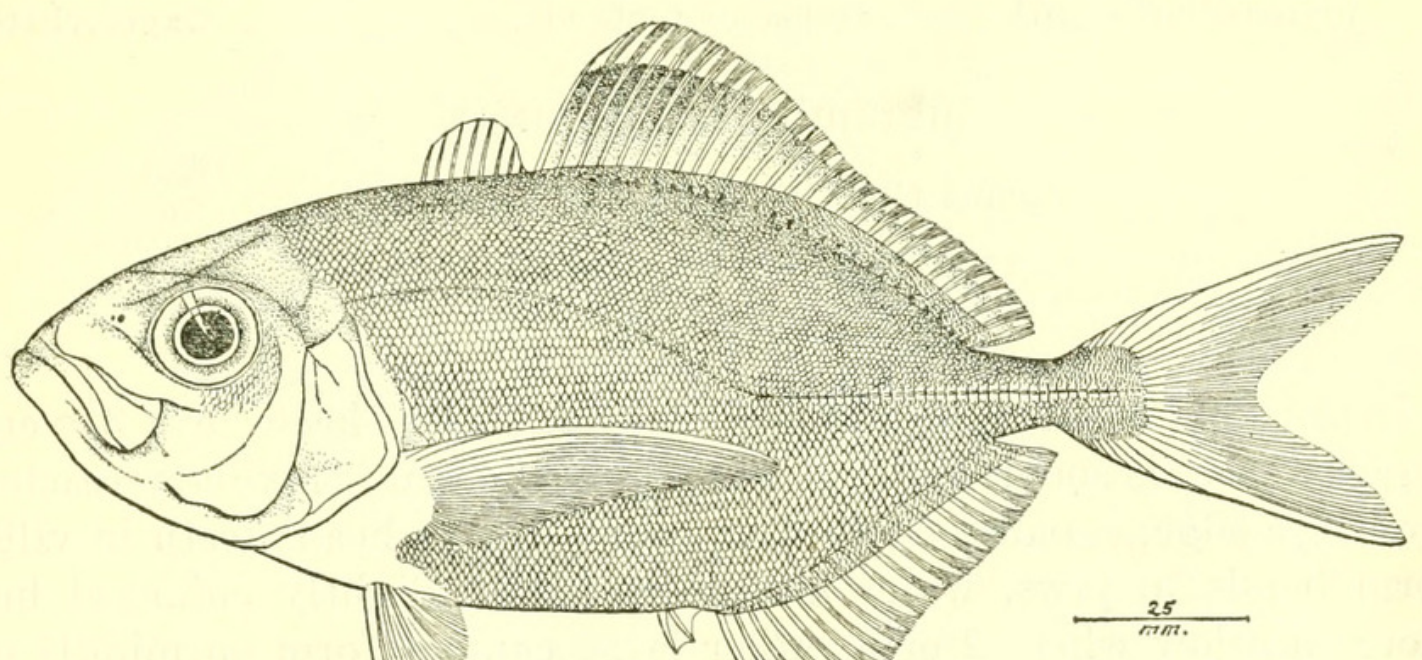

H. W.F. del.

Figure 17.-Uraspis pectoralis, new species. Type.

Gray above, silvery white below. Iris pale. Mouth inside black, roof and tongue white. Fins brownish.

Type.-U.S.N.M. no. 98820. (6328.) Manila Market, Philippine Islands. July 11, 1908. Length $215 \mathrm{~mm}$.

Distinguished chiefly by the long pectorals.

(pectoralis, with reference to its pectorals.)

\section{Family CIRRHITIDAE}

\section{ANALYSIS OF GENERA}

$a^{1}$. Cirrhitinae. Head small, jaws not greatly extended in front. $b^{1}$. Upper profile with deep notch, or incurved over eye; preopercle sharply serrate.

$c^{1}$. Soft dorsal rays 12 or 13

$c^{2}$. Soft dorsal rays 16 or 17 
$b^{2}$. Upper profile convex, with head deep and mouth low.

$d^{1}$. Scales cycloid, or nearly so.

$e^{1}$. Palatines with teeth anteriorly

Cirrhitus

$e^{2}$. Palatines toothless.

$f^{1}$. Dorsal origin nearly over hind edge of preopercle;

canines obsolete....................... Amblycirrhitus

$f^{2}$. Dorsal origin over pectoral base; canines in both

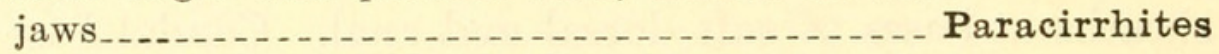

$d^{2}$. Scales large, rough ctenoid; cheeks with large scales;

canines small; palatines with teeth

Isobuna

$b^{3}$. Upper profile well inclined; straight or only slightly convex, muzzle pointed, moderate and mouth terminal.

$g^{1}$. Dorsal spines not half of body depth; scales in 5 or 6 rows on cheek

Cirrhitoidea

$g^{2}$. Fourth dorsal spine nearly as high as greatest body depth; scales in 4 rows on cheek

Acanthocirrhitus

$a^{2}$. Oxycirrhitinae. Head elongated, with long, extended snout;

premaxillaries with hind extensions toothed

Oxycirrhites

\section{Subfamily CIRRHITINAE}

\section{Genus CIRRHITICHTHYS Bleeker}

CIRRHITICHTHYS ANALIS, new species

Figure 18

Depth $23 / 4$; head $24 / 5$, width 2 . Snout $3 \frac{1}{5}$ in head; eye 3 , very slightly exceeds snout, greatly exceeds interorbital; maxillary reaches front eye edge, expansion $24 / 5$ in eye, length 3 in head; teeth in villiform bands in jaws, wider anteriorly, outer slightly enlarged but more so below where 2 or 3 rather large canines form on middle of each mandibular ramus; narrow band of fine teeth on each palatine and vomer; interorbital $5 \% 3$, concave; preopercle edge with 18 rather large denticles. Gill rakers $5+10$, lanceolate; $1 / 2$ of gill filaments, which $13 / 4$ in eye.

Scales $36+3$ in lateral line; 4 above, 10 below, 7 predorsal forward opposite hind eye edge; 4 rows on cheek below eye. Fins all scaly basally. Suprascapula with 8 denticles. Lateral line extends little high at first along side of caudal peduncle and becomes median at caudal base. Scales with 10 radiating basal striae; circuli fine, minute, not extended apically.

D. X, 12, I, third spine 2 in head, first branched ray $1 \frac{1}{2}$; A. III, 6 , I, second spine $1 \frac{1}{2}$, first ray $1 \frac{1}{3}$; caudal $1 \frac{1}{4}$, truncate; least depth of caudal peduncle 3 ; pectoral 1 , rays I, 7, VI, membranes of lowest or simple rays deeply incised; ventral rays $I, 5$, fin $1 \frac{2}{5}$ in head.

Pale brown generally, fins more or less whitish. Iris pale gray. Spinous dorsal with edges of eighth and ninth membranes broadly black. Scattered black spots, less than pupil, on soft dorsal. Small blackish brown spots on predorsal anteriorly and posterior part of 
interorbital. Small black spot above suprascapula and another on upper front part of opercle.

Type-U.S.N.M. no. 98901. (22124.) D. 5145. Jolo Light, S. $16^{\circ}$ E., 0.85 mile (lat. $6^{\circ} 4^{\prime} 30^{\prime \prime}$ N., long. $120^{\circ} 59^{\prime} 30^{\prime \prime}$ E.), vicinity of Jolo. In 23 fathoms. February 15, 1908. Length $69 \mathrm{~mm}$.

Remarks.-Only the type known. Greatly like Cirrhitopsis aureus (Schlegel), but differing chiefly in the longer second anal spine and distinct or contrasted dark to blackish spots on the head and dorsal fin.

(analis, with reference to the anal spines.)

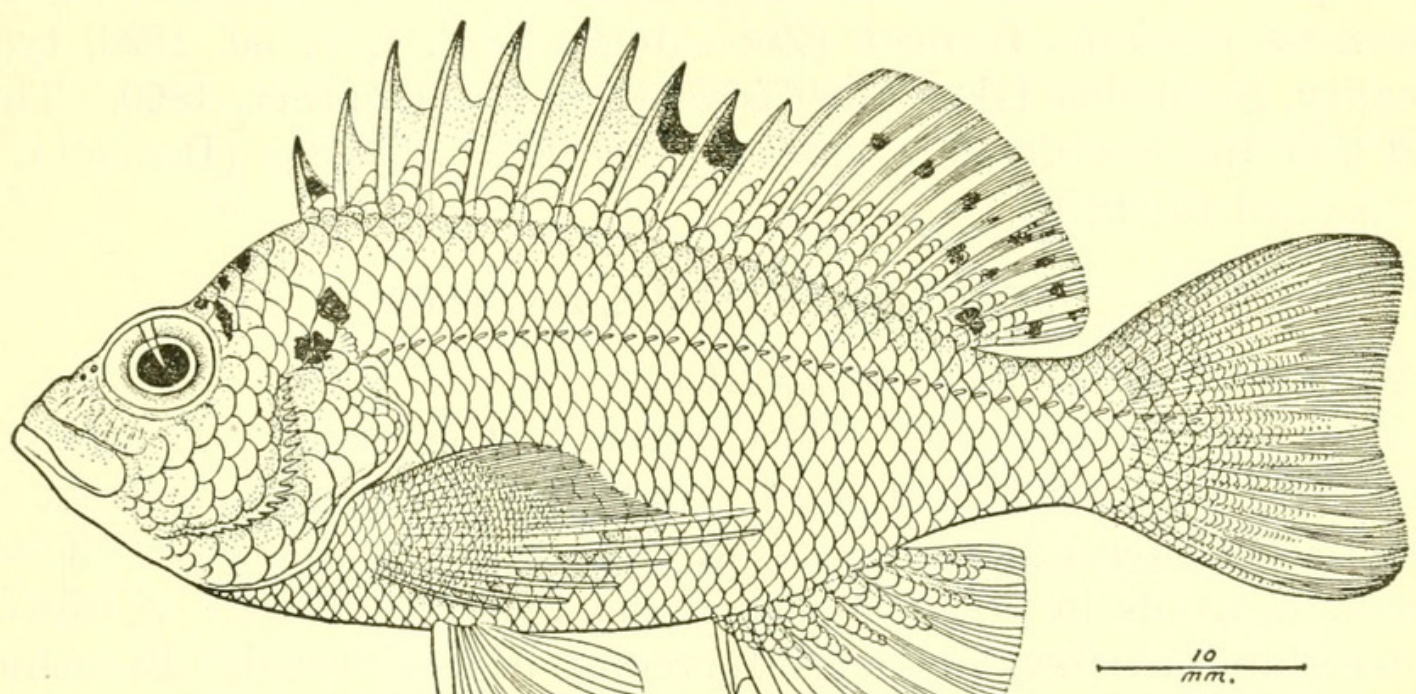

H.W.F. del.

Figure 18.-Cirrhitichthys analis, new species. Type.

\section{Genus AMBLYCIRRHITUS Gill}

AMBLYCIRRHITUS INDICUS, new species

Cirrhites fasciatus Cuvier (not Bennett, 1828), Histoire naturelle des poissons, vol. 3, p. 76, pl. 47, 1829 (type locality, Pondicherry).-Günther, Catalogue of the fishes of the British Museum, vol. 2, p. 73, 1860 (copied).-DAY, The fishes of India, pt. 1, p. 145, 1875 (copied) ; suppl., p. 788, 1888.

Amblycirrhitus fasciatus GILL, Proc. Acad. Nat. Sci. Philadelphia, 1862, p. 105 (reference).

Cirrhitichthys fasciatus DAY, The fauna of British India, Fishes, vol. 2, p. 51, 1889 (Madras).

Depth $2 \frac{1}{8}$; head 3 , width $22 / 5$. Snout 3 in head; eye $4,12 / 5$ in snout; maxillary reaches $1 / 2$ in eye, expansion $17 / 8$, length $22 / 3$ in head; teeth small, simple, conic, no canines; interorbital low, eye invading slightly front profile; hind preopercle edge serrate.

Scales $38+7$ in lateral series (on Cuvier's figure); 15 transversely between soft dorsal and anal origins; 8 rows on cheek to preopercle ridge. Vertical fins scaly basally. 
D. X, 12 , fourth spine $21 / 8$ in head, first ray $17 / 8$; A. III, 6 , second spine $1 \frac{1}{2}$, third ray $17 / 8$; caudal $1 \frac{1}{3}$, truncate; least depth of caudal peduncle $21 / 2$; pectoral $1 \frac{1}{1} 10$, rays $\Pi, 7$, v; ventral rays $I$, 5 , fin length $11 / 3$ in head.

Gray, white below. Small, scattered white spots on snout and predorsal. Four broad dark gray transverse bands on back, with narrower and paler one in each light interspace. Dorsals gray, with some small white spots. Other fins uniformly pale. (Cuvier, Day.) Remarles.-India. No length is given for the species, though Cuvier's figure measures $125 \mathrm{~mm}$. No material examined or seen.

Proposed to replace Cirrhites fasciatus Cuvier, preoccupied by Cirrhites fasciatus Bennett (Zool. Journ., vol. 4, p. 39, 1828, type locality, Sandwich Islands)=Cirrhites cinctus Günther, 1860. This last therefore antedated becomes Paracirrhites fasciatus (Bennett).

(Named for India.)

\section{ACANTHOCIRRHITUS, new genus}

Type.-Cirrhites oxycephatus Bleeker.

Body elongately ovoid. Head small. Snout conic. Eye rather high, median in length of head. Maxillary reaches below front of eye. Mouth terminal, rather low, jaws equal or subequal. Teeth small, in bands in jaws, on vomer and palatines, mostly villiform. Interorbital narrow, low. Preopercular edge serrated. Branchiostegals 6. Scales small in lateral series. Lateral line distinct, complete, axial. Dorsal spines graduated to fourth or longest spine, which equals about $4 / 5$ of greatest body depth. First dorsal ray longest, ends in filament, little longer than fourth dorsal spine. Anal spines long, but little shorter than fourth dorsal spine. Caudal rounded. Pectoral subequal with head. Ventral inserted well behind pectoral base.

One species, characterized by its long dorsal and anal spines. (äravta a, spine + Cirrhitus.)

\section{Family SCORPAENIDAE}

\section{ANALYSIS OF GENERA}

$a^{1}$. Body scaly, sometimes with fleshy or skinny flaps; pectoral without free rays.

$b^{1}$. Dorsal spines not greatly elongated with slender free tips; pectorals moderate.

$c^{1}$. Dorsal fins continuous, undivided.

$d^{1}$. Spinous dorsal begins well behind preopercle.

$e^{1}$. Sebastinae. Dorsal spines 13 to 16 ; front profile more or less oblique

Hoplosebastes

$e^{2}$. Scorpaeninae. Dorsal spines 12 .

$f^{1}$. Bones of head without large muciferous cavities; occiput with 2 pairs of spines; scales present, or with dermal flaps. * 
$g^{1}$. Some or all pectoral rays branched.

$h^{1}$. Lateral line developed, complete.

$i^{1}$. Palatine teeth present.

$j^{1}$. Scales on top of head ctenoid; armature of head moderate.

$k^{1}$. Air bladder well developed

Sebastiscus

$k^{2}$. Air bladder obsolete Helicolenus

$j^{2}$. Scales on top of head cycloid, or absent; no air bladder

Scorpaena

$i^{2}$. No palatine teeth.

$l^{1}$. Head scaly, also prepectoral region--- Scorpaenopsis

$l^{2}$. Only few scales on head behind eye and

on breast; prepectoral region and front

of belly naked

Scorpaenopsella

$h^{2}$. Lateral line incomplete, only on 4 or 5 scales be-

hind suprascapula

Phenacoscorpius

$g^{2}$. Pectoral rays all simple.

$m^{1}$. Lateral line without filaments.

$n^{1}$. No supraorbital tentacle

Hipposcorpaena

$n^{2}$. Supraorbital tentacle half of head.

Nemapontinus

$m^{2}$. Lateral line with row of filaments.

Crossoscorpaena

$f^{2}$. Bones of head with large muciferous cavities; spines of head little developed; scales deciduous, cycloid.

IMacroscorpius

$e^{3}$. Pterodichthrinae, new subfamily. Dorsal spines 11; anal spines 2

Pteropelor

$d^{2}$. Centropogoninae, new subfamily. Spinous dorsal begins

over vertical limb of preopercle

Centropogon

$c^{2}$. Plectrogeninae, new subfamily. Dorsal fins divided, first

with 10 spines and second with 7 rays

Plectrogenium

$b^{2}$. Pteroinae. Dorsal spines 12 or 13 , greatly extended, venomous; pectoral more or less elongate; top of head with spinous crests; anal spines 3 ; no palatine teeth.

$o^{1}$. Preorbital without tentacle, or only short filament present Brachypterois

$o^{2}$. Preorbital with exceedingly long tentacle or barbel Nemapterois

$a^{2}$. Body scaleless, or if scales present rudimentary, and sometimes with dermal flaps.

$p^{1}$. Scorpaenellinae, new subfamily. Dorsal spines 12, fin undivided; pectoral moderate, large, rays all simple, united; armature of head well developed Scorpaenella

$p^{2}$. Minoinae. Dorsal spines 10 or 11 , fin undivided ; pectoral moderate, lower ray detached; top of head with spinous crests_-_-_-_Minous

$p^{3}$. Inmicinae. Dorsal spines $\mathbf{1 5}$ to 18 , first 3 spines separated; 2 lower pectoral rays nearly detached Inimicus 


\section{Subfamily SEBASTinaE \\ Genus HOPLOSEBASTES Schmidt \\ HOPLOSEBASTES PRISTIGENYS, new species}

Figure 19

Depth $27 / 8$; head $21 / 4$, width $12 / 3$. Snout $34 / 5$ in head from snout tip; eye $4 \frac{1}{8}, 1 \frac{1}{8}$ in snout, greatly exceeds interorbital; maxillary reaches $1 / 2$ in eye, expansion $1 \frac{1}{2}$ in eye, length $17 / 8$ in head from snout tip; teeth minutely villiform, in bands in jaws, of which upper band little wider; narrow band of fine teeth on vomer; interorbital $6 \frac{1}{2}$, deeply concave, with deep median longitudinal channel. Gill rakers $6+11$, lanceolate, 4 or 5 above and below rudimentary; length $13 / 4$ in gill filaments, which 3 in eye.

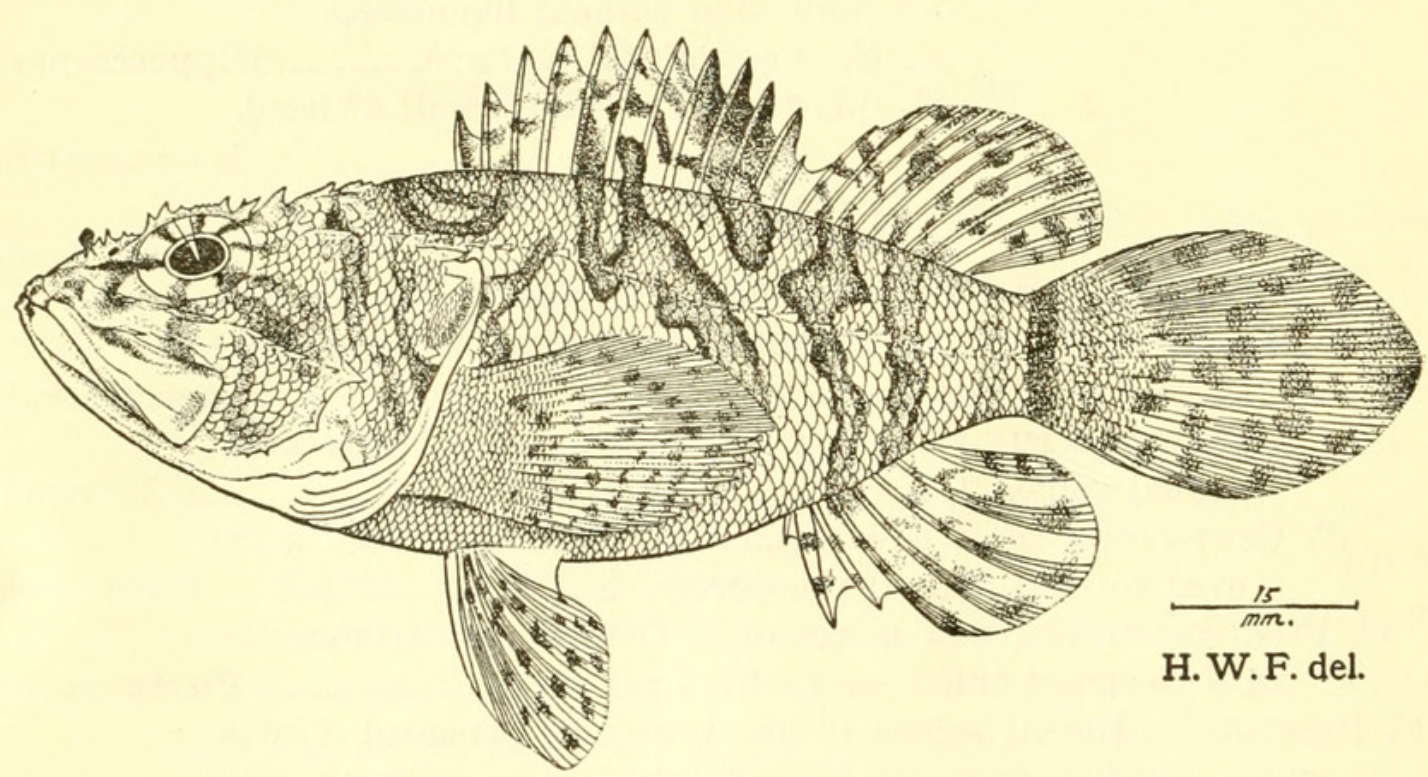

FigUre 19.-Hoplosebastes pristigenys, new species. Type.

Pair of nasal spines; 2 small anterosupraorbital spines each side, with posterior larger, then serrated edge of 5 points (entire on right supraorbital), followed by 2 postero-supraorbital spines (left double, right single), pair of coronals, pair of occipitals and finally pair of nuchals; 3 preorbital, median closer to posterior and both directed backward; suborbital stay with 8 spines (right stay with 12);4 preopercular spines, upper largest, next below minute; 3 postoculars, first small, others large and finally large double pronged suprascapular; 2 wide set opercular spines, opposite; strong humeral spine.

Scales $50+4$ close above and along lateral line; tubular scales $26+4$ in lateral line; 9 scales above, 14 below; 12 predorsal forward to occipital spines; 5 postocular scales. Head largely covered with small ctenoid scales, except muzzle and branchiostegal region. Small scales crowded on breast, prepectoral region, caudal base and belly. 
Lateral line complete, axial along side of body, with rather large tubes. Scales with 5 to 7 basal radiating striae; apical denticles 24 or 25 rather strong, conic, in 2 or 3 series; circuli fine.

D. XIII, 9 , I, fifth spine $24 / 5$ in total head length, third ray $21 / 8$; A. III, 5 , I, second spine $3 \frac{1}{2}$, second ray 2 ; caudal $12 / 5$, convex behind; least depth of caudal peduncle $4 \frac{1}{5}$; pectoral $1 \frac{1}{7}$, rays I, 8 , Ix ; ventral rays $\mathrm{I}$, 5 , fin $12 / 3$ in total head length.

Body pale brown, still little paler to whitish below. Two narrow, dark bands across interorbital. Dark band across occiput down to hind eye edge. Eye with dark brown bar forward, 3 others from its lower edge obliquely down. Narrow dark brown band from ends of occipital spines, crosses occiput and down side of head on front of opercle. Double dark brown predorsal band to middle of opercle and joined behind by broader band inclined from first 2 dorsal spines. Pair of dark brown bands down from behind fifth to sixth dorsal spines to below lateral line; another pair from ninth and tenth spines fused below and not reaching lateral line. Two dark bands down from soft dorsal well below lateral line. Pair of dark bands across caudal peduncle. All dark bands described bordered narrowly with still deeper brown. Fins light or whitish generally. Spinous dorsal with dark oblique bar from behind each spine. Fins otherwise all spotted with dark brown in contrast, as folded from dark transverse bars. Iris dark gray.

Type.-U.S.N.M.no. 98898. (6461.) D. 5305. Lat. $21^{\circ} 54^{\prime}$ N., long. $114^{\circ} 46^{\prime}$ E., China Sea, vicinity of Hong Kong. In 37 fathoms. October 24, 1908. Length $118 \mathrm{~mm}$.

Remarks.-A handsome species, with variegated color pattern, known only from the type. It is related to Hoplosebastes armatus Schmidt from Nagasaki, Japan, based on a single specimen 157.5 $\mathrm{mm}$ long. It differs in details of coloration, the larger and more extensive spots on the fins, scaleless maxillary, the presence of 3 anal spines, and in other features.

$\left(\pi \rho i \sigma \tau \iota s\right.$, saw $+\gamma^{\prime} \epsilon$ vuss, jaw.)

\section{Genus SEBASTISCUS Jordan and Starks}

SEBASTISCUS TRIACANTHUS, new species

F'igure 20

Depth $24 / 5$; head $21 / 4$, width 2. Snout $31 / 2$ in head from snout tip; eye $3 \frac{1}{2}$, equals snout, greater than interorbital; maxillary reaches $1 / 3$ in eye, expansion $2 \frac{1}{6}$ in eye, length $21 / 4$ in head from snout tip; teeth finely villiform, in narrow bands in jaws and on vomer and palatines; interorbital $61 / 5$, low, depressed, and with concave median channel. Gill rakers $7+15$, lanceolate, equals gill filaments or 3 in eye. 
Pair of small nasal spines; 1 antero-supraorbital and 2 posterosupraorbital spines; pair of small coronal spines, their points directed inward or toward one another; pair of long keels each end in small occipital spines, followed by short nuchal; 2 bifid preorbital spines, similar, on lower front edge over premaxillary; suborbital stay with 3 small, rather close set spines at middle of lower orbital rim; 5 preopercular spines, median largest and 2 lowest directed downward; 3 strong spines at supra-scapula, preceded by an elevated spine; 2 strong opercular spines, upper larger and slightly little posterior.

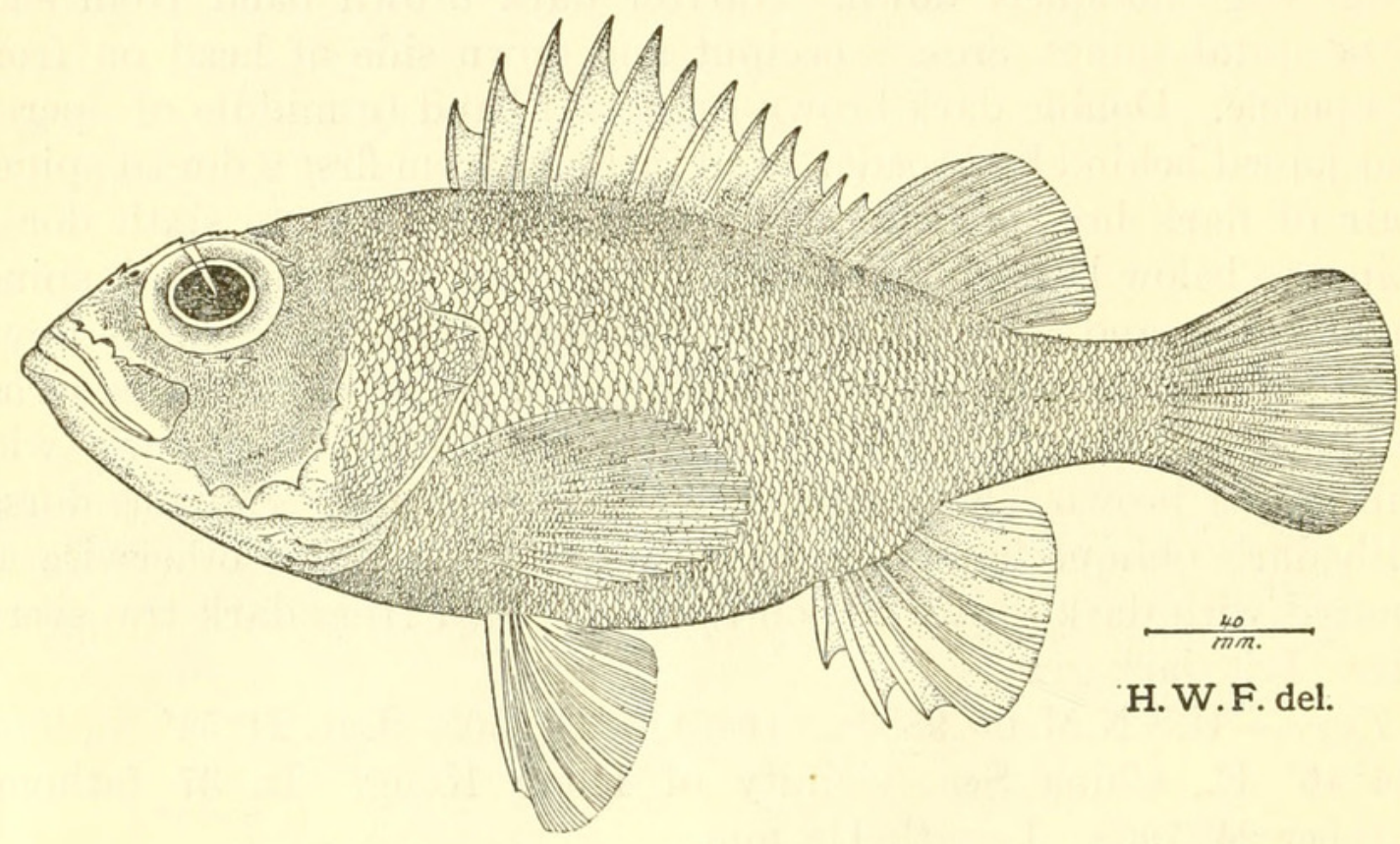

Figure 20.-Sebastiscus triacanthus, new species. Type.

Scales $60+7$ close along and above lateral line; $28+1$ tubular scales in lateral line; 14 above, 18 below, 16 predorsal forward to occipital groove about opposite tips of occipital spines and very small scales still forward to upper lip. Maxillary covered with very small scales, also mandible; $14+6$ scales obliquely down on cheek from lower eye edge. Fins with fine scales basally. Scales with 8 to 13 basal radiating striae; 30 to 33 slender, rather long denticles, with 2 or 3 transverse series of basal elements; circuli fine, coarser apically.

D.XII, 12 , I, fourth spine $22 / 3$ in total head length, third ray $23 / 5$; A. III, 6 , I, third spine $23 / 5$, first ray $2 \frac{1}{8}$; caudal 2 , little rounded behind; least depth of caudal peduncle $42 / 5$; pectoral $13 / 5$, rays I, 8 , viII; ventral rays I, 5 , fin 2 in total head length.

Uniform pale or light brown, without any markings. Iris pale. Fins all uniformly light.

Type.-U.S.N.M. no. 44912. Japan. Japanese Government. 1893. Length $333 \mathrm{~mm}$. 
Differs from Sebastiscus albofasciatus (Lacépède) in its apparent uniformly pale coloration, the presence of 3 small spines at the lower edge of the orbit and the bifid preorbital spines.

( $\tau \rho \epsilon \hat{\imath} s$, three $+\ddot{a} \kappa a \nu \theta a$, spine.)

\section{Genus SCORPAENA Linnaeus}

SCORPAENA AMPLISQUAMICEPS, new species

Figure 21

Depth 3 to $31 / 8$; head $2 \frac{1}{8}$ to $21 / 4$, width $2 \frac{1}{10}$ to $21 / 5$. Snout $41 / 5$ to $42 / 5$ in head from snout tip; eye $37 / 8$ to $4 \frac{1}{6}, 1$ in snout, greatly exceeds interorbital; maxillary reaches $3 / 5$ to $3 / 4$ in eye, expansion $14 / 5$ to 2 in eye, length $21 / 8$ to $21 / 4$ in head from snout tip; teeth in broad villiform bands in jaws, in narrower bands on vomer and palatines; interorbital $73 / 4$ to $81 / 8$, concave; occiput with very shallow depression. Gill rakers $5+10$, of which 3 or 4 above and 5 below rudimentary tubercles; gill rakers equal gill filaments or 4 in eye.

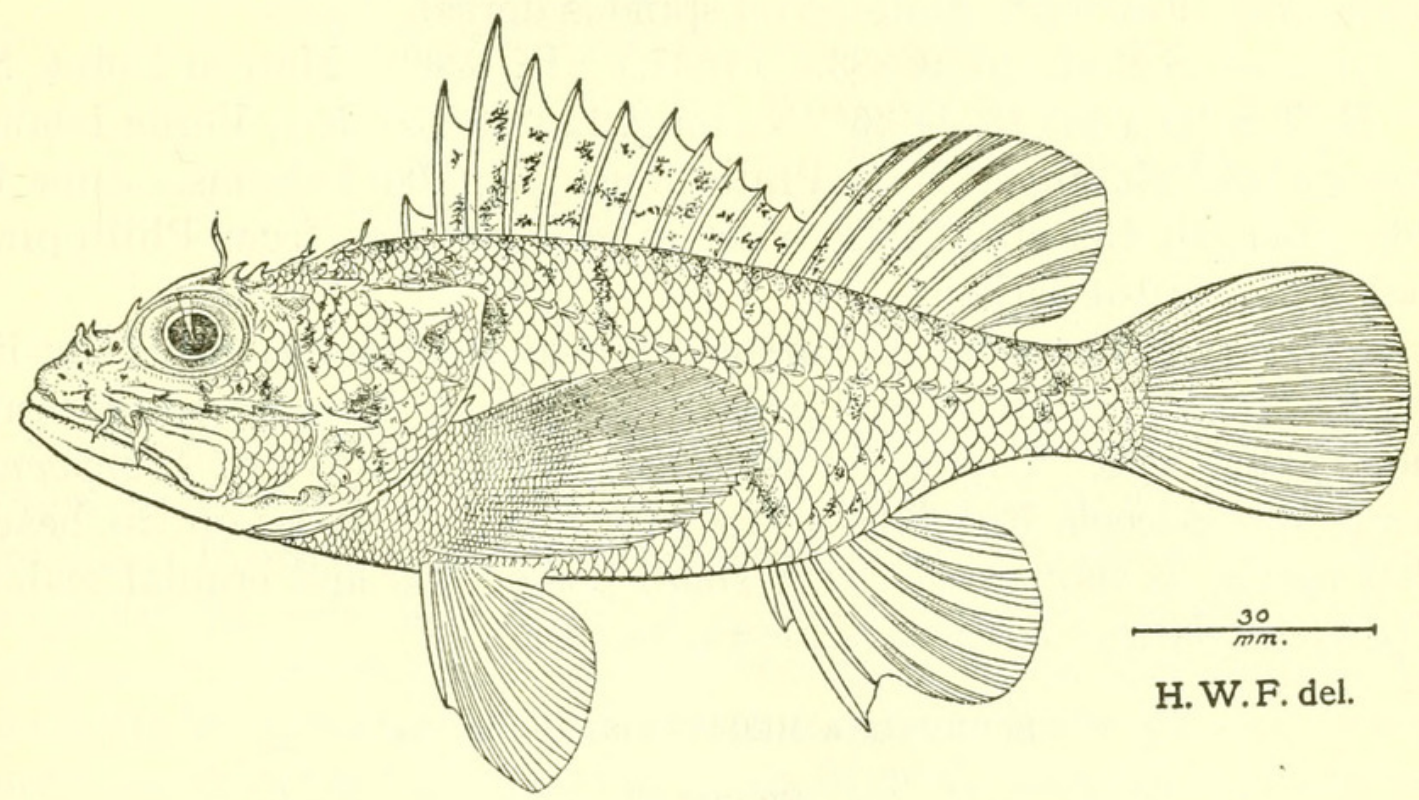

Figure 21.-Scorpaena amplisquamiceps, new species. Type.

Pair of nasal spines; pair of antero-supraorbital spines and 3 pairs of postero-supraorbital spines followed by occipital and nuchal pair; very small supero-postorbital spine, followed by 2 large spines, least of which close before suprascapular spine; 2 preorbital spines, both directed backward; suborbital stay with 4 spines, first of which on preorbital bone; 4 preopercular spines, upper longest and with small prebasal spine; 2 wide set opercular spines, opposite one another; rather blunt humeral spine.

Scales 33 to $37+2$ or 3 close above and along lateral line; tubular scales 22 or $23+1$ in lateral line; 7 scales above, 11 below; 10 predorsal 
scales forward to occiput or about opposite occipital spines, or about 18 forward until opposite hind pupil edge; 3 postoculars; scales on head all large, none on muzzle, front of interorbital, maxillary and branchiostegal region. Scales on breast, chest, prepectoral region, pectoral base and belly all much smaller than other body scales; scales on caudal base moderately small. Lateral line axial, high at first, complete; tubes simple, long, each well exposed. Scales with 15 to 18 basal radiating striae; 60 to 71 short, slender, apical denticles, with 1 or 2 transverse series of basal elements; circuli fine.

D. XII, 9 , I, third spine $2 \frac{1}{6}$ to $27 / 8$ in total head length, fifth ray $21 / 6$ to $22 / 5$; A. III, 5 , I, second spine $23 / 5$ to $2 \frac{2}{3}$, second ray $2 \frac{1}{4}$ to $23 / 5$; caudal $1 \frac{1}{2}$ to $13 / 4$, hind edge convex; least depth of caudal peduncle $43 / 4$ to $5 \frac{1}{2}$; pectoral $13 / 4$ to $17 / 8$, rays II, 7 or 8 , xI; ventral rays $I, 5$, fin 2 in total head length.

Brown, mottled with darker and paler obscurely on back and sides. Iris grayish. Fins all pale or light, with dark basal blotch on spinous dorsal at bases of second and third membranes, and at base of sixth membrane. Few faint blotches on spinous dorsal.

Type-U.S.N.M. no. 98883. (1637.) D. 5266. Matoco Point, S. $22^{\circ}$ E., 7 miles (lat. $13^{\circ} 44^{\prime} 36^{\prime \prime}$ N., long. $120^{\circ} 59^{\prime} 15^{\prime \prime}$ E.), Verde Island Passage and Batangas Bay, Philippines. In 100 fathoms. June 8, 1908. Length $152 \mathrm{~mm}$. Also a series of paratypes from Philippine seas, in 100 to 161 fathoms.

Remarks.-Known by its combination of characters, especially its small scales on the breast and prepectoral region, large scales on head and its large eye. Though in some respects suggestive of Scorpaena bucephalus Alcock, it differs in the greatly larger scales on the head. That species is shown with very small postorbital and cranial scales.

(amplus, large + squama, scale + ceps, head.)

\section{SCORPAENA MEGALEPIS, new species}

\section{Figure 22}

Depth $23 / 4$ to $33 / 5$; head 2 to $21 / 8$, width $17 / 8$ to $21 / 4$. Snout $3 \frac{4}{5}$ to $41 / 4$ in head from snout tip; eye $31 / 3$ to $41 / 5$, greater than snout in young to subequal with age, greatly exceeds interorbital; maxillary reaches $1 / 2$ to $3 / 5$ in eye, expansion $1 \frac{1}{2}$ to 2 , length 2 in head from snout tip; teeth villiform, in moderately wide bands in jaws and narrow band on vomer and palatines; interorbital $81 / 2$ to $83 / 5$, concave. Gill rakers $5+12$, of which 3 or 4 above and below as rudimentary tubercles; lanceolate, equal gill filaments or 3 in eye.

Pair of nasal spines; pair of antero-supraorbital spines and 3 pairs of postero-supraorbital spines, followed by a pair of occipitals and a pair of nuchals; occipital depression slight; 3 postocular spines, first small and finally small suprascapular spine; small and incon- 
spicuous tympanic spine close over third postocular spine; 2 preorbital spines, posterior larger and directed little backward; suborbital stay with 4 spines, of which first on preorbital bone; 4 preopercular spines, upper largest, with small spine on outer basal part; 2 widely divergent opercular spines, lower little posterior; humerus with broad rounded keel, without spine.

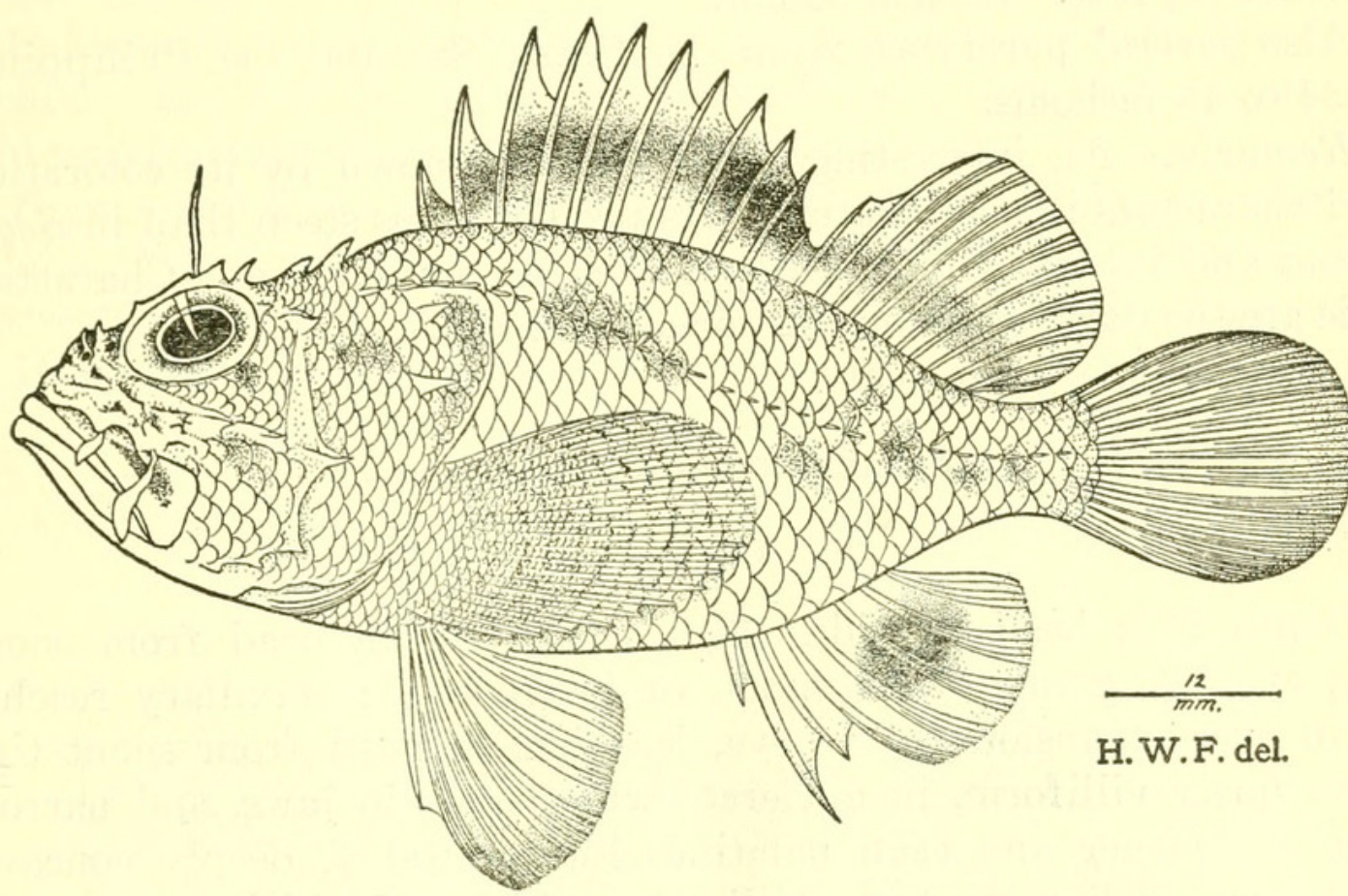

Figure 22.-Scorpaena megalepis, new species. Type.

Scales 25 to $28+2$ close along and above lateral line; tubular scales 22 or $23+1$ or 2 in lateral line; 4 scales above, 9 below; 10 predorsal forward opposite hind pupil edge; 3 postoculars. Scales on postocular, cheek and opercle, little smaller on occiput, rest of head naked. Moderate scales on breast, chest, prepectoral region, and caudal base, though much smaller than lateral scales of body; small scales on pectoral base. Lateral line high at first, axial, complete. Scales with 7 or 8 basal radiating striae; 55 to 58 apical denticles, with 3 or 4 transverse series of basal elements; circuli fine. Nostril with filament; first postero-supraorbital spine with filament nearly long as eye; filament at occipital spine, long, fringed flap and posterior preorbital spine, and another at upper preopercular spine.

D. XII, 9, I or 10, I, third spine $21 / 2$ to $22 / 3$ in total head length, fourth ray $2 \frac{1}{4}$ to $22 / 3$; A. III, 5 , I, second spine $2 \frac{1}{4}$ to $2 \frac{2}{5}$, first ray $21 / 4$ to $2 \frac{1}{3}$; caudal $1 \frac{4}{5}$, convexly rounded behind; least depth of caudal peduncle $4 \frac{1}{8}$ to 5 ; pectoral $13 / 5$ to $1 \frac{2}{3}$, rays $\mathrm{I}, 9$, $\mathrm{x}$; ventral I, 5 , fin $14 / 5$ to 2 in total head.

Body brownish, mottled or variegated obseurely with darker on back and sides. Under portions paler to whitish. Fins pale generally. Spinous dorsal with median row of dark blotches, obscurely 
defined at eighth to tenth spines, membranes entirely blackish over greater terminal portions. Soft dorsal with subbasal dark or brownish band. Anal with grayish transverse band medially. Pectoral with few indistinct grayish spots on each of upper rays.

Type-U.S.N.M. no. 98897. (6462.) D. 5305. Lat. $21^{\circ} 54^{\prime}$ N., long. $114^{\circ} 46^{\prime}$ E., China Sea, vicinity of Hong Kong. In 37 fathoms. October 24, 1908. Length $98 \mathrm{~mm}$.

Also several paratypes from the China Sea and the Philippines in 34 to 45 fathoms.

Remarks.-An interesting small species, known by its coloration and characters in combination. Its profile is less steep than in Scorpaena and its eye smaller in specimens of similar size. Characteristic are the dark bands on the dorsals and anals.

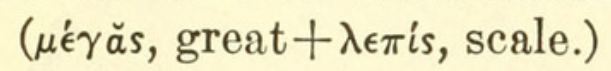

\section{SCORPAENA GIBBIFRONS, new species}

FIgure 23

Depth $23 / 5$; head 2, width $14 / 5$. Snout $42 / 5$ in head from snout tip; eye $33 / 5$, greater than snout, or interorbital; maxillary reaches $4 / 5$ in eye, expansion $12 / 3$ in eye, length 2 in head from snout tip; teeth finely villiform, in moderate wide bands in jaws, and narrow band on vomer and each palatine; interorbital 7, deeply concave, with deep median channel. Gill rakers $6+12$, of which 3 or 4 rudimentary above and below; clavate, 3 in eye; gill filaments $3 / 4$ of gill rakers.

Pair of small nasal spines; pair of small antero-supraorbital and 3 pairs of posterosupraorbital spines, followed by pair of occipitals and nuchals, of which latter much longest; 2 small spines on upper hind orbital edge, followed by 2 large postocular spines and a suprascapular; 2 preorbitals posterior larger and directed down and back; suborbital stay with 3 spines; preopercular spines 5, uppermost longest and with small prebasal spine; then third spine below equally long though intermediate or second spine small; 2 wide set opercular spines, upper much larger, about opposite; broad, strong spine on humerus.

Scales $28+2$ along and close above course of lateral line; tubular scales $21+1$ ? in lateral line; 5 scales above, 8 below ; 7 predorsal forward to occiput; 3 postocular. Head scaled on postocular, cheek and opercle, otherwise naked. Scales on chest and breast rather large, small on pectoral and caudal bases. Lateral line complete, high at first, axial; tubes large, simple and well exposed. No fleshy flap in pectoral axil. Scales with 11 to 14 basal radiating striae; 50 to 62 
small, slender, apical denticles, with 1 or 2 series of basal elements transversely; circuli fine, coarser or obsolete apically.

D. XII, 9, I, third spine 2 in total head length, second branched ray $2 \frac{1}{5} ;$ A. III, 5 , I, second spine $21 / 3$, first branched ray $2 \frac{1}{2}$; caudal $15 \%$, evidently rounded (damaged) behind; least depth of caudal peduncle $47 / 8$; pectoral $13 \%$, rays II, 4 , $\mathrm{xI}$; ventral I, 5 , fin $1 \frac{9}{10}$ in total head length.

Pale brown generally, blotched or clouded obscurely with paler and lighter. Iris very light brown. Fins all pale, with obscure whitish and pale brown bars or spots. Ventral whitish.

Type.-U.S.N.M. no. 98900. (4277.) D. 5482. Cabugan Grande Island (N.), N. $87^{\circ}$ W., 4.5 miles (lat. $10^{\circ} 27^{\prime} 30^{\prime \prime}$ N., long. $125^{\circ} 18^{\prime}$ E.), between Samar and Leyte, vicinity of Surigao Strait. In 67 fathoms. July 30, 1909. Length $89 \mathrm{~mm}$.

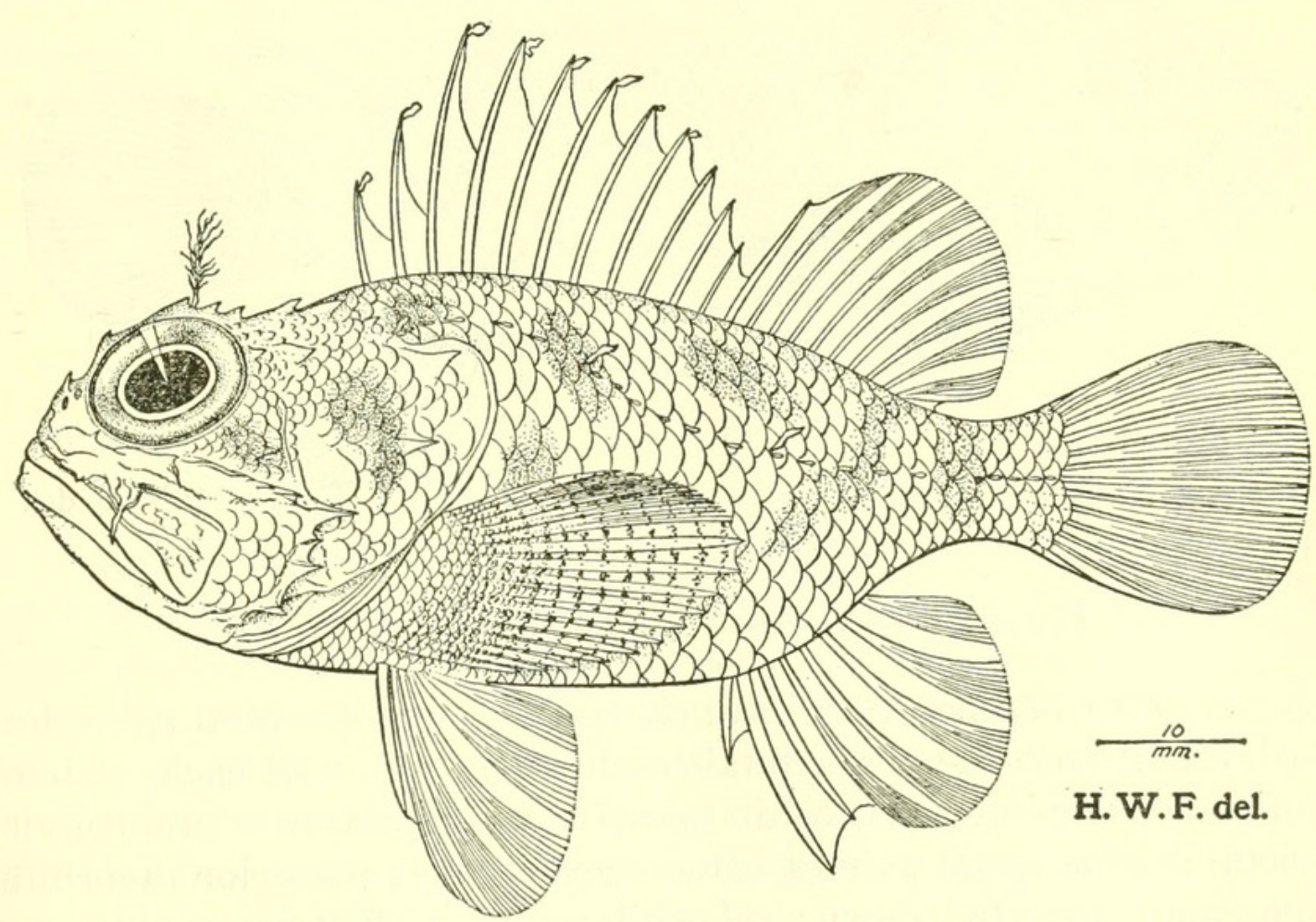

Figure 23.-Scorpaena gibbifrons, new species. Type.

Remarks.-Only the type known. Somewhat resembles Sebastapistes coloratus Gilbert, here regarded as a Scorpaena, but differing in its scaly head, no blackish blotch on spinous dorsal and much larger scales. Also the scales on the postocular smaller than elsewhere on the head in Scorpaena megalepis. Scorpaena bucephalus Alcock agrees with my species in this respect, as well as in other characters, but it has a difierent physiognomy with a more extended and less abrupt muzzle, shorter pectoral, and it is figured with much smaller scales.

(gibbifrons, short front, or short snout.) 
SCORPAENA MCADAMSI, new species

Figure 24

Depth $2 \frac{1}{2}$ to $24 / 5$; head $2 \frac{1}{10}$ to $21 / 8$, width $1 \frac{1}{2}$ to $12 / 3$. Snout $31 / 2$ to 4 in head from snout tip; eye $32 / 5$ to 4 , subequal with snout, greater than interorbital; maxillary reaches $1 / 2$ to $3 / 5$ in eye, expansion $12 / 5$ to $13 / 5$, length $14 / 5$ to $17 / 8$ in head from snout tip; teeth in narrow, villiform bands in jaws, on vomer and palatines; interorbital 5 to $53 / 4$, deeply concave; occipital depression moderate, transverse, close behind level of eyes. Gill rakers $5+8$, short tubercles $1 / 2$ of gill filaments, which $23 / 4$ in eye.

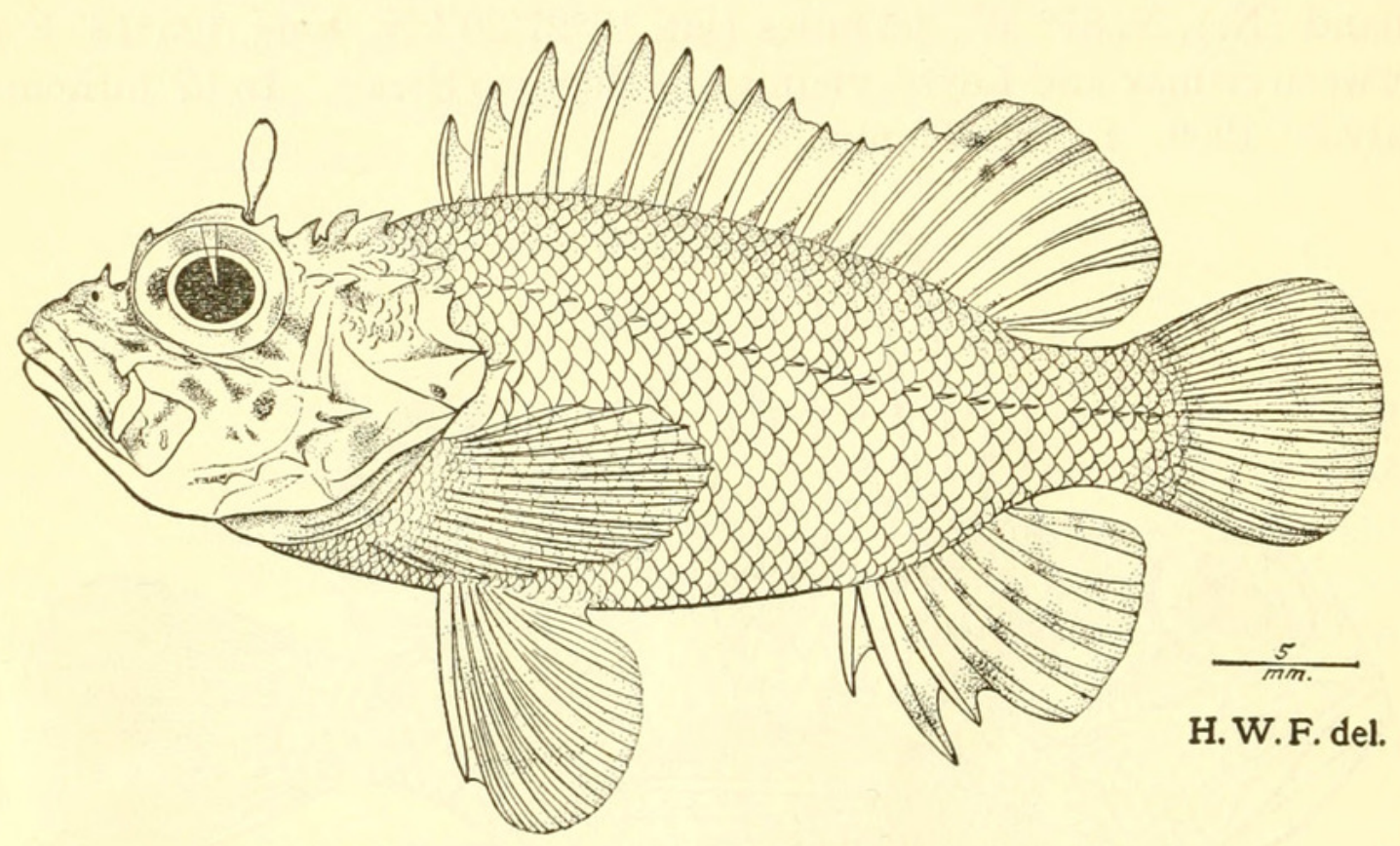

Figure 24.-Scorpaena mcadamsi, new species. Type.

Nasal pair of spines moderate; short antero-supraorbital spine forward, and 2 postero-supraorbitals each side, close, well back; pair of strong nuchal spines, close behind posterior of 2 postero-supraorbitals; parietal and occipital pair of spines each strong; posterior preorbital . spine small, directed down; suborbital stay with 2 short spines; 4 preopercular spines, with small auxiliary at uppermost basally; strong postocular; suprascapular spine present; 2 opercular spines; humeral spine well developed.

Scales $27+3$ close above and along lateral line; tubular scales $21+$ in lateral line; 6 scales above, 12 below; 5 predorsal. Opercle and postocular region scaly above. Usually fringed supraocular flap, at least long as eye. Scales with 7 or 8 short, marginal, subparallel basal striae; circuli 18 to 20 , moderate.

D. XII, 10, fourth spine $2 \frac{2}{5}$ to $21 / 2$ in total head length, second ray 2 to 3 ; A. III, 5 , second spine 2 to $21 / 4$, second ray $14 / 5$ to $17 / 8$; caudal 
$11 / 2$ to $13 / 5$, convex behind; least depth of caudal peduncle $31 / 2$ to $41 / 5$; pectoral from origin $1 \frac{1}{2}$ to $13 / 5$, rays 15 ; ventral rays $I$, 5 , fin $1 \frac{1}{2}$ to $13 / 4$ in total head length.

Largely uniform brown, fins little paler. Iris gray. From ninth to eleventh dorsal spines marginally and submarginally with blackish blotch. Caudal with slight longitudinal dark band on middle of each half of fin longitudinally.

Type-C.S.N.M. no. 98904. (1816.) $\quad$ D. 5174. Jolo Light, E. 2.6 miles (lat. $6^{\circ} 3^{\prime} 45^{\prime \prime}$ N., long. $120^{\circ} 57^{\prime}$ E.), in vicinity of Jolo. In 20 fathoms. March 5, 1908. Length $49 \mathrm{~mm}$.

Series of paratypes.-D. 5254. Linao Point, N. $44^{\circ}$ E., 0.7 mile (lat. $7^{\circ} 5^{\prime} 42^{\prime \prime}$ N., long. $125^{\circ} 39^{\prime} 42^{\prime \prime}$ E.), Gulf of Davao. In 21 fathoms. May 18, 1908 . Length 35 to $45 \mathrm{~mm}$.

Remarks.-Distinguished by its combination of characters, especially the simple pectoral rays, the second preorbital spine directed down and its supraocular flap, dark blotch on spinous dorsal and usually uniform coloration. In these respects it differs from Scorpaena bandanensis Bleeker.

(Named for Fred McAdams, of Cape May, N. J., to whom I am indebted for many interesting off-shore American fishes.)

\section{SCORPAENA PALLIDIMACULA, new species}

Figure 25

Depth 3 ; head 2, width $2 \frac{1}{10}$. Snout $4 \frac{1}{4}$ in head from snout tip, over twice eye diameter; orbit $33 / 5$ in head from snout tip; maxillary reaches $2 / 3$ in orbit, expansion $13 / 4$ in eye, length 2 in head from snout tip; mandible with moderate, bony, symphyseal spur; teeth finely villiform, in moderately broad bands in jaws, and narrow bands on vomer and palatines; interorbital 10, deeply concave, with 2 distinct longitudinal keels; slight depression on cranium. Gill rakers $7+12$, of which 3 or 4 above and below rudimentary tubercles; length $11 / 2$ in gill filaments, which $31 / 2$ in adult.

Pair of small nasal spines; pair of antero-supraorbital spines and 3 pairs of postero-supraorbital spines, followed by pair of occipitals and larger pair of nuchals; small spine at upper hind edge of orbit, followed by 2 long spines and then 1 at suprascapula; 2 preorbital spines, posterior larger and directed little down and backward; suborbital stay with 3 spines; 3 preopercular spines, uppermost longest and with small prebasal spine; 2 wide set opercular spines, lower little posterior; very blunt, short, humeral spine.

Scales $40+3$ close along and above lateral line; tubes $24+1$ ? in lateral line; 5 scales above, 12 below; 17 predorsal forward to hind 
eye edge; 3 or 4 postocular scales. Head with ctenoid scales, large on cheek, postocular region, opercle and top of head, rest naked. Scales moderately small on chest, breast, prepectoral region and caudal base. Lateral line high at first, axial along side of body, complete; tubes large, simple, single, well exposed. Scales with 6 to 11 basal radiating striae; 19 to 30 short slender apical denticles; circuli fine basally, coarser to obsolete terminally. Small cutaneous filaments at nostril, antero-supraorbital spine, first of postero-supraorbital spines and upper opercular spine.

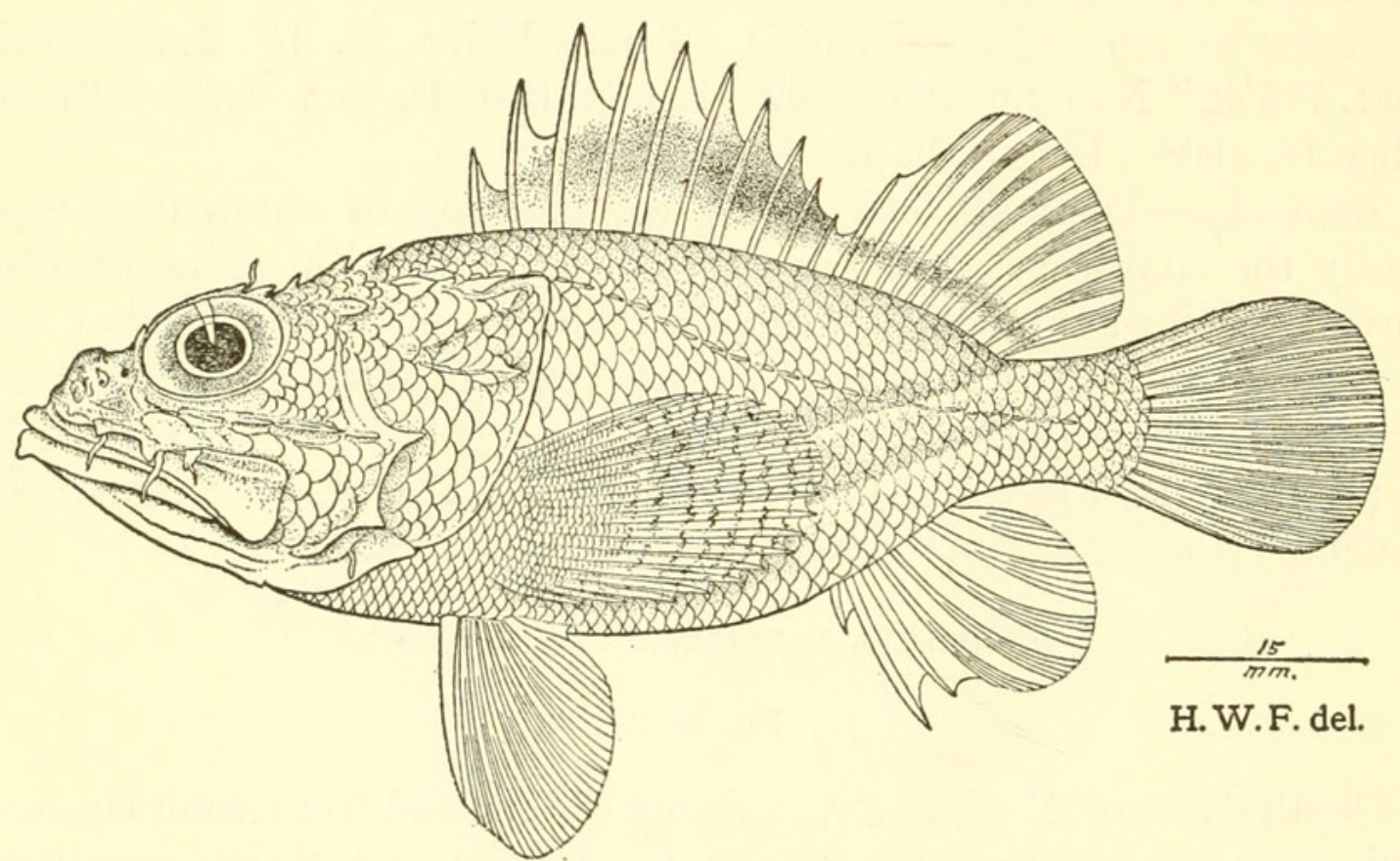

Figure 25.-Scorpaena pallidimacula, new species. Type.

D. XII, 10 , I, fourth spine $23 / 4$ in total head length, third ray 3 ; A. III, 5 , I, second spine $23 / 5$, first ray $27 / 8$; caudal 2 , little convex behind; least depth of caudal peduncle 5 ; pectoral $17 / 8$, rays I, $9, \mathbf{x}$; ventral I, 5, length 2 in head.

Pale brownish, with some slightly darker cloudings on back and sides, under surfaces paler. Iris pale gray. Fins pale. Dark brown blotch on seventh to ninth membranes of spinous dorsal. Soft dorsal with some obscure brown shades on membranes.

Type.-U.S.N.M. no. 98889. (2557.) D. 5241. Uanivan Island (N.), S. $68^{\circ}$ E., 3 miles (lat. $6^{\circ} 50^{\prime} 45^{\prime \prime}$ N., long. $126^{\circ} 14^{\prime} 38^{\prime \prime}$ E.), Pujada Bay and vicinity. In 215 fathoms. May 14, 1908. Length $98 \mathrm{~mm}$.

Remarks.-Known by its large eye, dark blotch on the spinous dorsal, and general physiognomy.

(pallidus, pale +macula, spot; with reference to the inconspicuous blotch on the spinous dorsal.) 
OsORIOIA, new subgenus

Type.-Scorpaena hemilepidota, new species.

Body elongately ovoid, well compressed, back little elevated. Head large, compressed. Snout broad, rather obtuse. Eye moderate, reaches upper profile and nearly before middle in head length. Maxillary reaches below eye, well expanded behind. Mouth large, lower jaw slightly protruded. Bands of teeth in jaws, and on vomer and palatines. Interorbital deeply concave, with median channel. Slight quadrate depression at occiput. Gill opening large, membranes only slightly united in front. Gill rakers few, rather thick and blunt. Armature of head strong. Scales rather large, ctenoid. Head, breast, chest, prepectoral region and front of belly naked. Lateral line complete, high at first, axial along side of body; tubes distinct. Few rather short skinny flaps on head. Dorsal continuous, soft fin smaller and little higher than spinous. Anal small, second spine longest, though third but little shorter and first slightly more than second. Pectoral with broad base, fin rather short. Ventral inserted opposite pectoral origin, fin large.

Differs from subgenus Scorpaena in its naked head, shoulder girdle, breast, and front of belly.

(Named for Dr. Balthazar Osorio, in commemoration of his many important contributions to African ichthyology.)

\section{SCORPAENA HEMILEPIDOTA, new species}

\section{Figure 26}

Depth $2 \frac{7}{8}$; head $2 \frac{1}{8}$, width 2 . Snout $34 / 5$ in head from snout tip; eye $6,13 / 5$ in snout, 1 in interorbital; orbit $42 / 5$ in head from snout tip, $1 \frac{1}{4}$ in snout, little greater than interorbital; maxillary reaches $2 / 3$ in eye, expansion $12 / 5$ in eye, length 2 in head from snout tip; teeth in villiform bands in jaws, where widest, and narrow on vomer and palatines; interorbital $63 / 4$ in head from snout tip. Gill rakers $6+13$, of which 5 are above and below rudimentary tubercles; others robust and obtuse compressed rods, $1 \frac{1}{4}$ in gill filaments, which $14 / 5$ in eye.

Pair of nuchal spines; pair of antero-supraorbital and 2 pairs of postero-supraorbital spines, with little closer pair of coronals posteriorly, followed by pair of occipital and nuchal spines; cluster of 3 short, small, supero-postocular spines and finally large suprascapular spine; tympanic spine above last postocular smaller; 2 preorbital spines, posterior larger and directed downward; suborbital stay with 3 spines; 5 preopercular spines, upper largest and with small prebasal spine; pair of divergent opercular spines, opposite one another; strong humeral spine pointing obliquely up and back.

$36541-38-3$ 
Scales $32+3$ close along and above on lateral line; tubular scales $23+1$ in lateral line; 5 scales above, 14 below; 6 predorsal forward to occiput. Head, breast, chest, prepectoral and front of belly naked. Small scales on posterior part of abdomen. Lateral line complete,

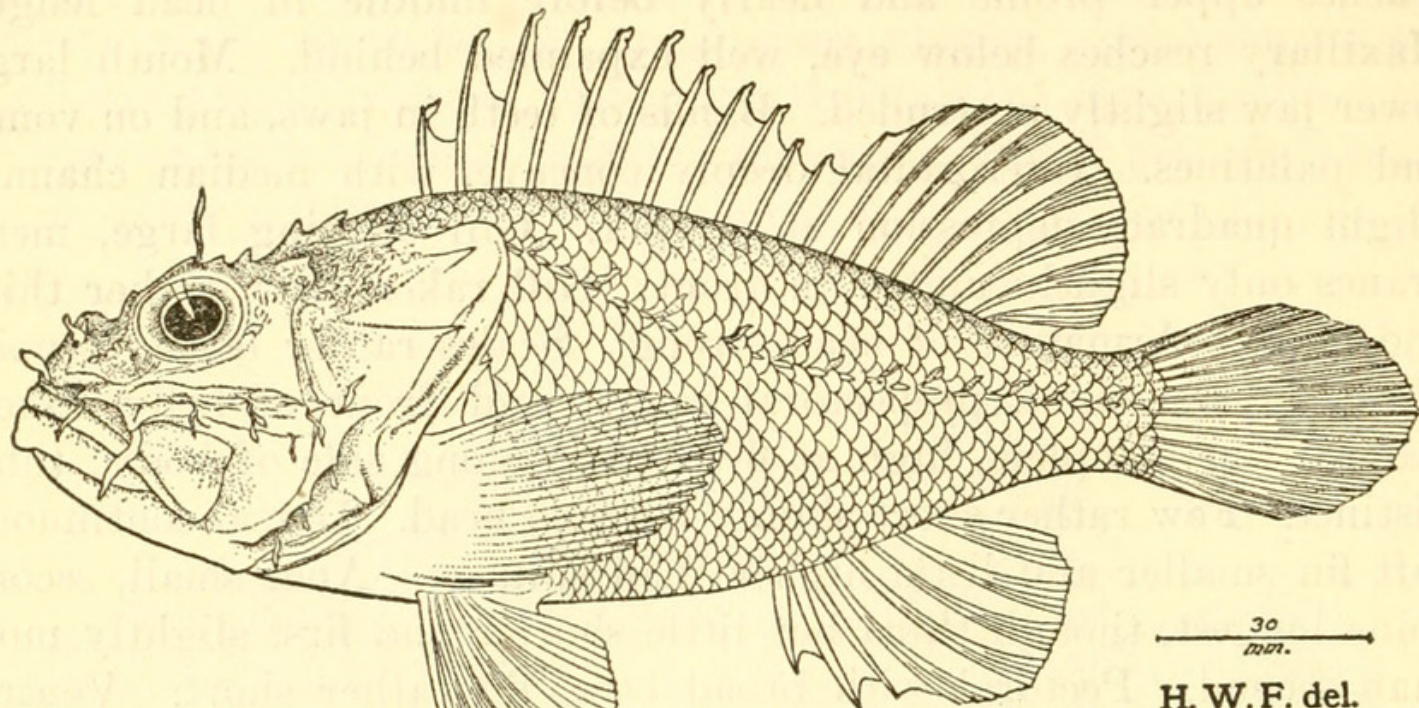

H. W.F. del.

Figure 26.-Scorpaena hemilepidota, new species. Type.

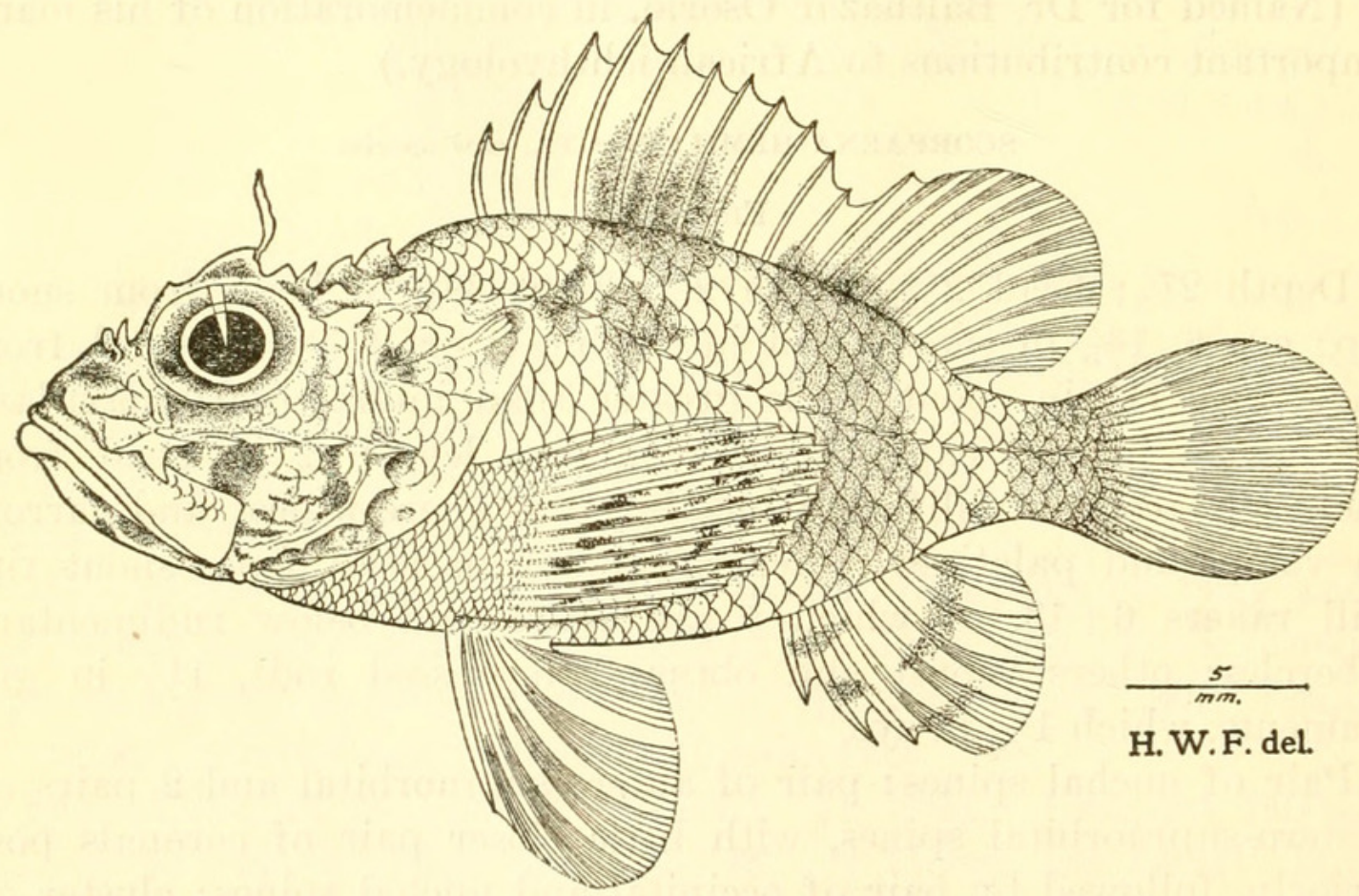

Figure 27.-Scorpaenopsis cotticeps, new species. Type.

continuous, axial along side of body; tubes long, simple, well exposed. Scales with 10 to 14 basal radiating striae; 31 to 33 slender, uniform, apical denticles; circuli very fine. Nostril, each supraorbital spine, occipital spines, preorbital spines and those of sub- 
orbital stay, preopercular spines, humeral spine, and lateral line with skinny flaps or filaments.

D. XI, I, 9, third spine $2 \frac{2}{3}$ in total head length, fourth ray $2 \frac{1}{8}$; A. III, 5 , I, second spine $3 \frac{1}{4}$, second ray $2 \frac{1}{2}$; caudal $13 / 5$, convex behind; least depth of caudal peduncle $4 \frac{2}{3}$; pectoral $14 \frac{4}{5}$, rays I, 7 , xI; ventral I, 5 , fin 2 in total head length.

Light brownish generally, body clouded or shaded more brownish above, under surfaces paler to whitish. Iris gray-brown. Fins all pale brown.

Type-U.S.N.M. no. 98884. (3521.) D. 5392. Tubig Point, N. $49^{\circ}$ E., 5 miles (lat. $12^{\circ} 12^{\prime} 35^{\prime \prime}$ N., long. $124^{\circ} 2^{\prime} 48^{\prime \prime}$ E.), between Samar and Masbate. In 135 fathoms. March 13, 1909. Length $202 \mathrm{~mm}$.

$(\dot{\eta} \mu \check{\imath}$, half $+\lambda \epsilon \pi \check{\imath} \delta \omega \tau o \dot{s}$, scaled.)

\section{Genus SCORPAENOPSIS Heckel}

SCORPAENOPSIS COTTICEPS, new species

Figure 27

Depth $22 \%$; head 2 , width 2 . Snout 3 in head from snout tip; eye $37 / 8$ in head from snout tip, $1 \frac{1}{10}$ in snout, greater than interorbital; maxillary reaches $3 / 4$ in eye, expansion $1 \frac{1}{3}$, length $1 \frac{9}{10}$ in head from snout tip; teeth fine, villiform, minute, in bands in jaws and on vomer, none on palatines; interorbital $52 / 3$, deeply convex; deep bean-shaped pit or depression on occiput. Gill rakers $4+10$, low tubercles, $1 / 2$ of gill filaments, which 2 in eye.

Pair of slender nuchal spines; pair of small antero-supraorbital spines, and 2 pairs of broad postero-supraorbital spines, pair of small tympanics, pair of broad parietals, and pair of broad occipitals; 2 postoculars each side, hind one larger; temporal spine moderate; suprascapular spine low; 2 widely diverging preorbital spines each side, front one directed forward and posterior directed backward; suborbital stay with 4 low spines; 4 preopercular spines, upper longest and with basal auxiliary; 2 divergent opercular spines; humeral spine well developed.

Scales $26+3$ along, and close above, in lateral line; pores $20+$ in: lateral line; 5 scales above, 11 below, 6 predorsal. Opercle with few small scales. Small scales on breast, chest, and prepectoral region. Scales with 6 or 7 basal radiating striae; $10+10$ uniform low, weak, apical denticles; circuli fine.

D. XII, 10 , fourth spine $23 / 4$ in total head length, first ray $23 / 4$; A. III, 5 , second spine 3 , second ray $2 \frac{1}{4}$; caudal $1 \frac{1}{2}$, convex behind; least depth of caudal peduncle $51 / 3$; pectoral $12 / 5$, rays 14 , all simple; ventral rays $\mathrm{I}, 5$, fin $14 \%$ in total head. 
Light brown, mottled with brown. Fins all pale. Iris brassy. White spots on lower sides of head and mandible. Pectoral rays with small brown spots.

Type.-U.S.N.M. no. 98891. D. 5159. Tinakta Island (N.), N. $82^{\circ}$ W., 1.40 miles (lat. $5^{\circ} 11^{\prime} 50^{\prime \prime}$ N., long. $119^{\circ} 54^{\prime}$ E.), Sulu Archipelago, Tawi Tawi Group. In 10 fathoms. February 21, 1908. Length $38 \mathrm{~mm}$.

(Cottus, sculpin $+\kappa \epsilon \phi \check{a} \lambda \dot{\eta}$, head.)

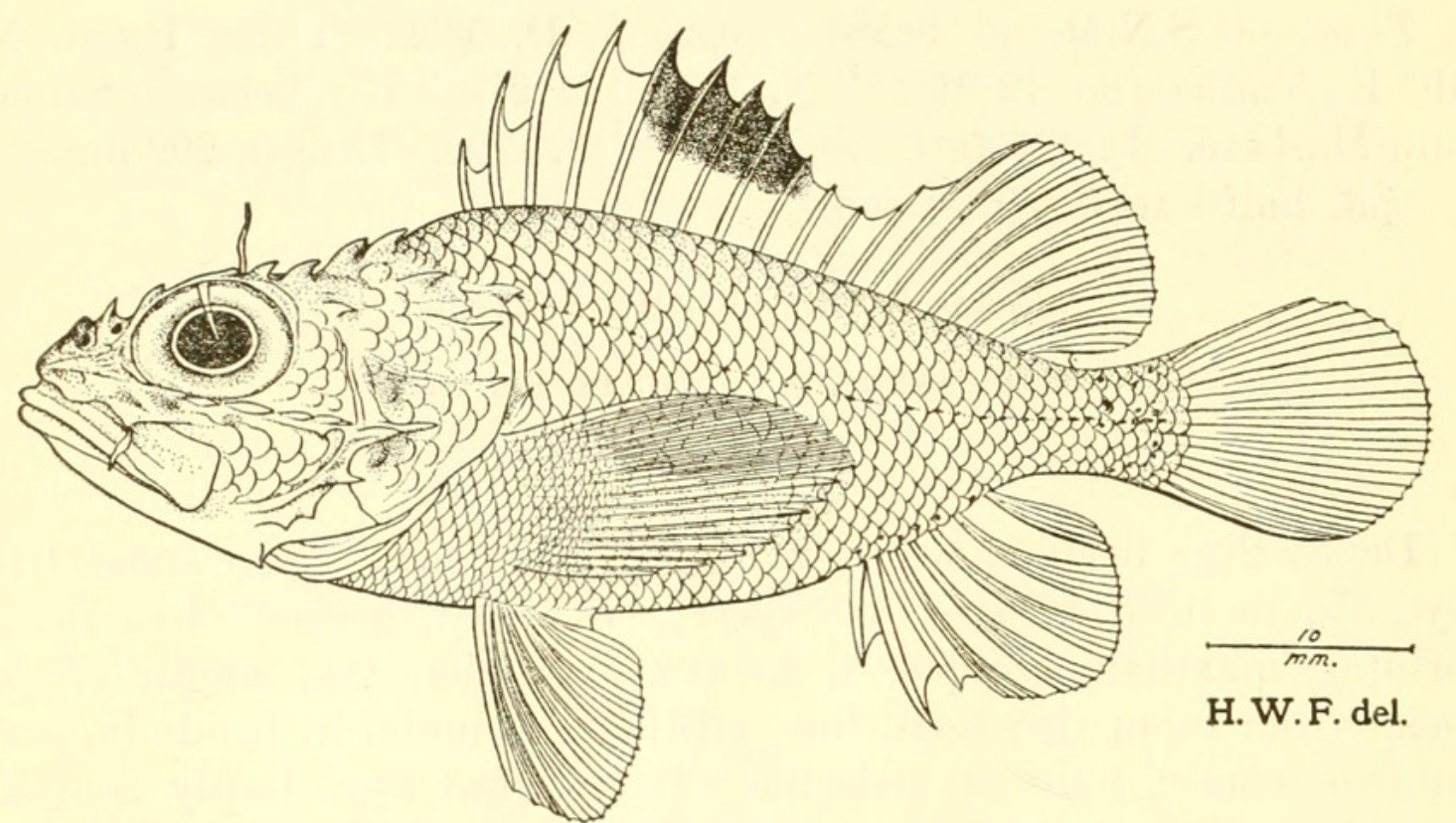

Figure 28.-Scorpaenopsis stigma, new species. Type.

SCORPAENOPSIS STIGMA, new species

Figure 28

Depth $27 / 8$; head $21 / 4$, width $1 \frac{1}{2}$. Snout 4 in head from snout tip; eye 3, greater than snout, much greater than interorbital; maxillary reaches opposite $2 / 5$ in eye, expansion $13 / 4$ in eye, length $15 / 6$ in head from snout tip; minute, villiform teeth in bands in jaws and small band on vomer, none on palatines; interorbital 9 in head, deeply concave. Gill rakers $6+14$, lanceolate; gill filaments $3 / 4$ of gill rakers, which $3 \frac{1}{2}$ in eye.

Pair of strong nasal spines behind front pair of nostrils; low antero-supraorbital spine and 2 greatly higher, strong postero-supraorbital spines each side, followed by coronal pair, then large parietal pair and finally occipital pair; strong postocular spine over top of preopercle, followed by another over top of opercle and one at suprascapula; 2 broadly obtuse preorbital spines; suborbital stay with 5 strong spines, followed by strong spine at preopercle angle, last with outer prebasal spine; lower preopercle edge with 3 spines of which upper directed back and 2 lower directed downwards; 2 
wide set opercular spines, lower little posterior; strong, oblique humeral spine.

Scales $26+2$ in lateral line; 4 above, 9 below, 13 predorsal forward to middle of eye, of which 5 extend forward to occiput; 2 postocular to preopercle ridge. Scales small on chest, breast, belly, prepectoral region and caudal base. Cirri at antero-supraorbital spine, first postero-supraorbital, behind each parietal, posterior preorbital and second preopercular. Lateral line little high at first, axial, tubes small, simple, and inconspicuous. Scales with 6 or 7 basal radiating striae; 7 or 8 close set short apical denticles; circuli fine, concentric, many rings extended apically.

D. XII, 9, I, third spine $2 \frac{2}{3}$ in total head length, third ray $23 / 4$ ?; A. III, 5 , second spine $21 / 5$, third ray 2 ; caudal $14 / 7$, rounded behind; least depth of caudal peduncle 5 ; pectoral $1 \frac{1}{2}$, rays I, 6 , viII; ventral rays $I, 5$, fin 2 in total head length.

Body brown, head and fins paler to whitish. Iris gray. Black blotch large as eye on membrane of spinous dorsal from fifth to tenth spines.

Type-U.S.N.M. no. 98896. D. 5518. Point Tagolo Light, S. $64^{\circ}$ W., 8.7 miles (lat. $8^{\circ} 48^{\prime}$ N., long. $123^{\circ} 31^{\prime}$ E.), northern Mindanao and vicinity. In 200 fathoms. August 9, 1909. Length $69 \mathrm{~mm}$.

Also paratype. Same data. Length $68 \mathrm{~mm}$.

Remarls.-Characterized by its heavy armature of the head with cirri, absence of palatine teeth, lowest 8 pectoral rays simple, short gill rakers and the large conspicuous black blotch on the spinous dorsal.

( $\sigma \tau i \gamma \mu a$, spot, with reference to the spinous dorsal.)

\section{SCORPAENOPSELLA, new genus}

Type-Scorpaenopsella armata, new species.

Body elongately ellipsoid or greatest depth midway in the standard length, well compressed. Head large, nearly half of standard length, well compressed. Snout rather obtusely conic. Eye large, impinging on upper profile, well advanced in head. Mouth large, superiorly terminal, or with lower jaw protruded and furnished with low, blunt or rounded symphyseal knob. Maxillary reaches below eye, cxpanded behind. Teeth small, pointed, in 4 or 5 irregular rows above; fewer rows below and with outer enlarged row, which alone extends posteriorly in jaws. Interorbital deeply concave. Gill opening very large, membrane forming narrow fold across isthmus. Head with but few scales behind eye and on opercle. Scales on body rather small. Lateral line complete, conspicuous. No scales on chest, prepectoral or front of belly. Spinous dorsal 
lower than soft dorsal, fins not deeply notched. Anal small, second spine longest, third subequally shorter, first less than half of second. Caudal moderate. Pectoral rather short, with broad deep base. Ventral inserted before pectoral origin.

Small fishes like Scorpaenopsis but only with scales on the head behind eyes and on breast, the prepectoral region and front of the belly naked. The armature of the head strong.

(Scorpaena $+\omega \psi$, appearance + ella, diminutive.)

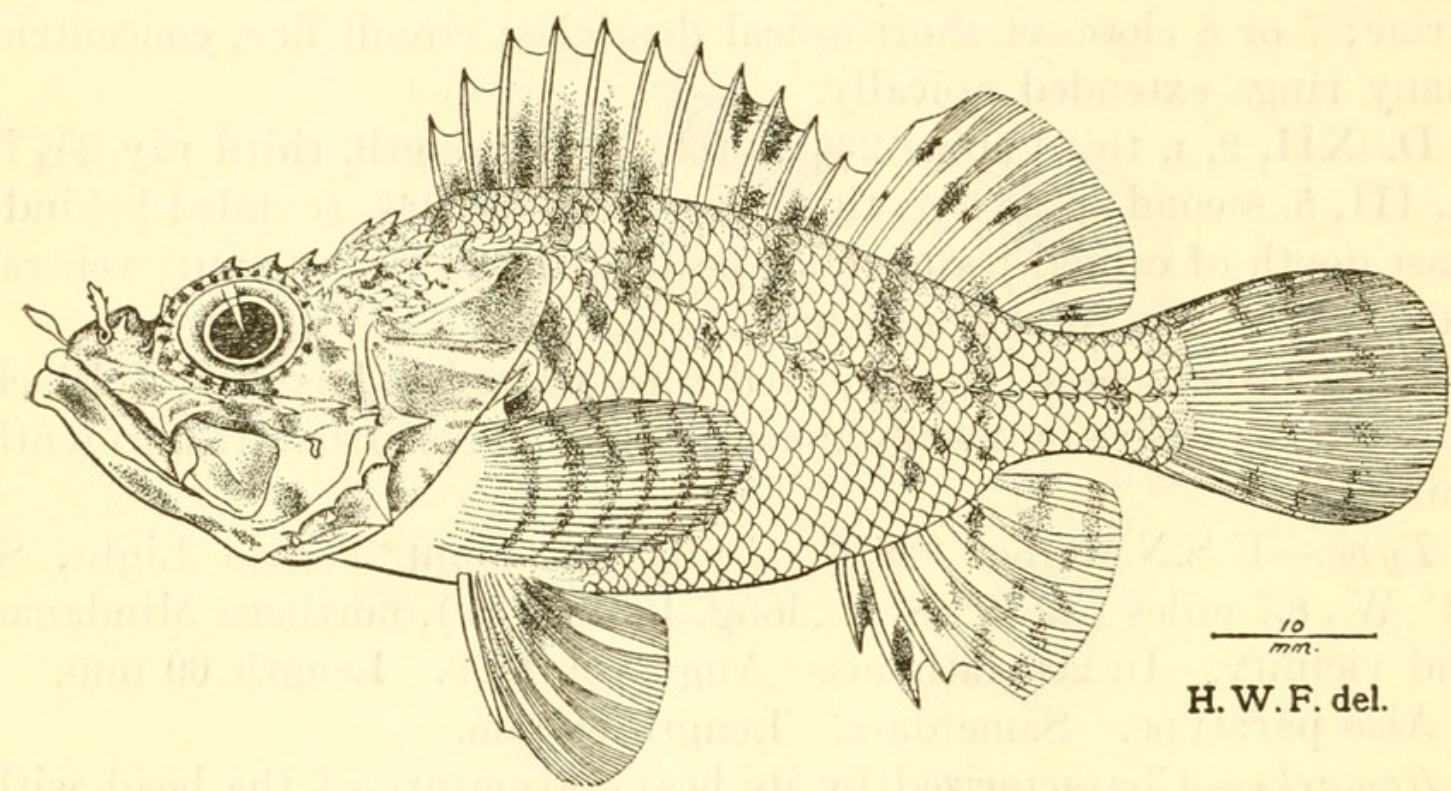

Figure 29.-Scorpaenopsella armata, new genus, new species. Type.

SCORPAENOPSELLA ARMATA, new species

Figure 29

Depth $23 / 4$; head $21 / 8$, width $17 / 8$. Snout $37 / 8$ in head from snout. tip; eye $4 \frac{1}{2}, 1 \frac{1}{4}$ in snout, greatly exceeds interorbital; orbit $37 / 8$ in head from snout tip, equals snout; maxillary reaches $1 / 2$ in eye, expansion $1 \frac{1}{3}$ in eye, length 2 in head from snout tip; teeth small, pointed, moderately broad band above, lower band narrower with outer row little enlarged and along whole extent of mandible; triangular band of small teeth on vomer, none on palatines; interorbital 7 , deeply concave, with deep, median, longitudinal channel; rather deep quadrate occipital depression. Gill rakers $6+12$, of which 4 or 5 above and below short asperous tubercles; gill rakers subequal with gill filaments, which 3 in eye.

Pair of short, strong nasal spines; antero-supraorbital spines low and 3 pairs of postero-supraorbital spines, followed by occipital and nuchal pair; 2 small suprapostocular spines, followed by 2 large ones and finally suprascapular spine; small tympanic spine over and close to second (fourth of entire series) large postocular; blunt anterior preorbital spine directed downward; suborbital stay with 3 spines; 5 
preopercular spines, upper largest, with small spine before its base externally; 2 wide set opercular spines, opposite, lower nearly reaching gill opening; strong humeral spine inclined back and upward.

Scales $37+3$ ? close above and along lateral line; tubular scales $23+1$ ? in lateral line; 6 scales above, 14 below ; 3 postocular; 9 predorsal to occipital spines. Head largely naked, except patch of few postocular scales and small area on upper part of opercles. Chest, breast, prepectoral region, front of abdomen and pectoral bases naked. Lateral line high, slopes along side of body axially; tubes large, simple, well exposed. Scales with 8 or 9 basal radiating striae; apical denticles 17 to 20, slender, rather long, uniform; circuli fine. Flap long as pupil each side of snout tip; large fringed flap from front nostril; small filament from first postero-supraorbital spine; large flap from second preorbital spine.

D. XII, 9 , I, third spine $31 / 10$ in total head length, third ray $23 / 5$; A. III, 5 , I, second spine $31 / 4$, first ray $21 / 2$; caudal $12 / 3$, convex behind; least depth of caudal peduncle 5 ; pectoral $19 \% 10$, rays II, 7 , xI ; veniral rays $I$, 5 , fin 2 in total head length.

Light brown, paler to whitish below. Obscure darker brown bar across predorsal and 5 others from bases of dorsals on back, first at fifth dorsal spine, second at seventh, third at eleventh, fourth at third dorsal ray, fifth at seventh. Dark bar from lower eye edge down on cheek. Spinous dorsal with dark brown terminally on membranes as well as basally. Soft dorsal with obscure brown blotches. Several gray spots on pale or whitish anal. Caudal whitish, with 3 or 4 very indistinct darker transverse bars. Pectoral brown, with 4 dark bars transversely, outer 2 wider. Ventral whitish, little brownish terminally.

Type.-U.S.N.M. no. 98893. (2098.) D. 5117. Sombrero Island, S. $17^{\circ}$ E., 10.8 miles (lat. $13^{\circ} 52^{\prime} 22^{\prime \prime}$ N., long. $120^{\circ} 46^{\prime} 22^{\prime \prime}$ E.), Balayan Bay and Verde Island Passage. In 118 fathoms. January 21, 1908. Length $88 \mathrm{~mm}$.

(armata, armed, with reference to the spines on the head.)

\section{PHENACOSCORPIUS, new genus}

\section{Type.-Phenacoscorpius megalops, new species.}

Body compressed, elongately ovoid, back but little elevated. Head large, compressed. Snout short, obtuse, less than eye. Eye large, nearly in front half of head, meets upper profile. Mouth large, closed jaws nearly even. Maxillary reaches below eye, expanded behind. Teeth in villiform bands in jaws, on vomer, none on palatines. Interorbital narrow, concave. Gill opening wide, membranes scarcely united, free from isthmus. Gill rakers lanceolate. Pseudobranchiae well developed. Spines of head strongly developed, 
large, conspicuous, with high keels and sharp points. Few slender filaments on head. Scales large, weakly ctenoid, cover most of head, but fins except caudal base naked. Lateral line very short, only slightly developed on several anterior scales. Dorsals moderately notched, spines moderate and soft fin shorter than spinous. Anal like soft dorsal, spines slender, second largest. Caudal rounded. Pectoral moderate, reaches anal. Ventral small, inserted slightly before pectoral.

Characterized chiefly by its imperfect lateral line, large scales, heavy armature of the head and large eyes.

( $\phi \dot{e} \nu 0 \xi$, cheat + Scorpius, with reference to the incomplete lateral line.)

\section{PHENACOSCORPIUS MEGALOPS, new species}

\section{Figure 30}

Depth $24 / 5$ to 3 ; head $21 / 5$ to $2 \frac{1}{3}$, width $13 / 4$ to $17 / 8$. Snout 4 to $41 / 5$ in head from snout tip; eye $31 / 2$ to $33 / 5$, greater than snout or interorbital; orbit $31 / 8$ to $32 / 5$ in head from snout tip; maxillary reaches $1 / 2$ in eye, expansion $1 \frac{1}{2}$ to $17 / 8$ in eye, length 2 in head from snout tip; teeth finely villiform, in bands of moderate width in jaws, and small triangular band on vomer, none on palatines; interorbital $81 / 2$ to $91 / 3$, deeply concave. Gill rakers $7+14$, lanceolate, of which 4 or 5 above and below rudiments; slightly longer than gill filaments or 3 in orbit.

Spines all well developed, strong; pair of nasals; pair of anterosupraorbitals, 3 pairs of postero-supraorbitals followed by 2 strong occipital and nuchal pairs; 3 postoculars, first small and close behind eye; strong suprascapular spine; 2 very broad obtuse preorbitals; suborbital stay with 6 or 7 spines, of which last may be double; 4 preopercular spines, with small one at outer front edge of uppermost, which longest; 2 widely divergent opercular spines, opposite and lower sometimes extends over gill opening; strong oblique humeral spine.

Scales $30+3$ close above and along axial row of scales on side; 14 or 15 scales transversely at origins of soft dorsal and spinous anal; 3 postocular scales; 17 predorsal forward to middle of eyes. Lateral line very incomplete, only extends from suprascapula back over 4 or 5 scales, tubes large, well exposed and simple. Scales with 8 to 12 basal radiating striae; row of 14 to 18 rather long, weak apical denticles; circuli fine, coarser apically. Scales much smaller on breast, chest, and belly than on sides. More or less slender, simple, filaments at second supraorbital, occipital and second preorbital spines. 
D. XII, 9 , I, fourth spine $27 / 8$ to 3 in head, fourth ray $2 \frac{1}{6}$ to $2 \frac{1}{3}$; A. III, 5 , I, second spine $23 / 5$ to $22 / 3$, third ray $2 \frac{1}{8}$ to $2 \frac{1}{5}$; caudal $14 / 5$ to $17 / 8$, rounded convexly behind; least depth of caudal peduncle $41 / 5$ to $4 \frac{4}{5}$; pectoral $1 \frac{1}{3}$ to $1 \frac{2}{5}$, rays I, 8 , vIII; ventral rays $\mathrm{I}, 5$, fin $17 / 8$ to 2 in total head length.

Pale brownish generally. Iris grayish above. Fins all pale to whitish. Spinous dorsal with dark brown to blackish blotch on sixth or seventh (or even eighth) membranes.

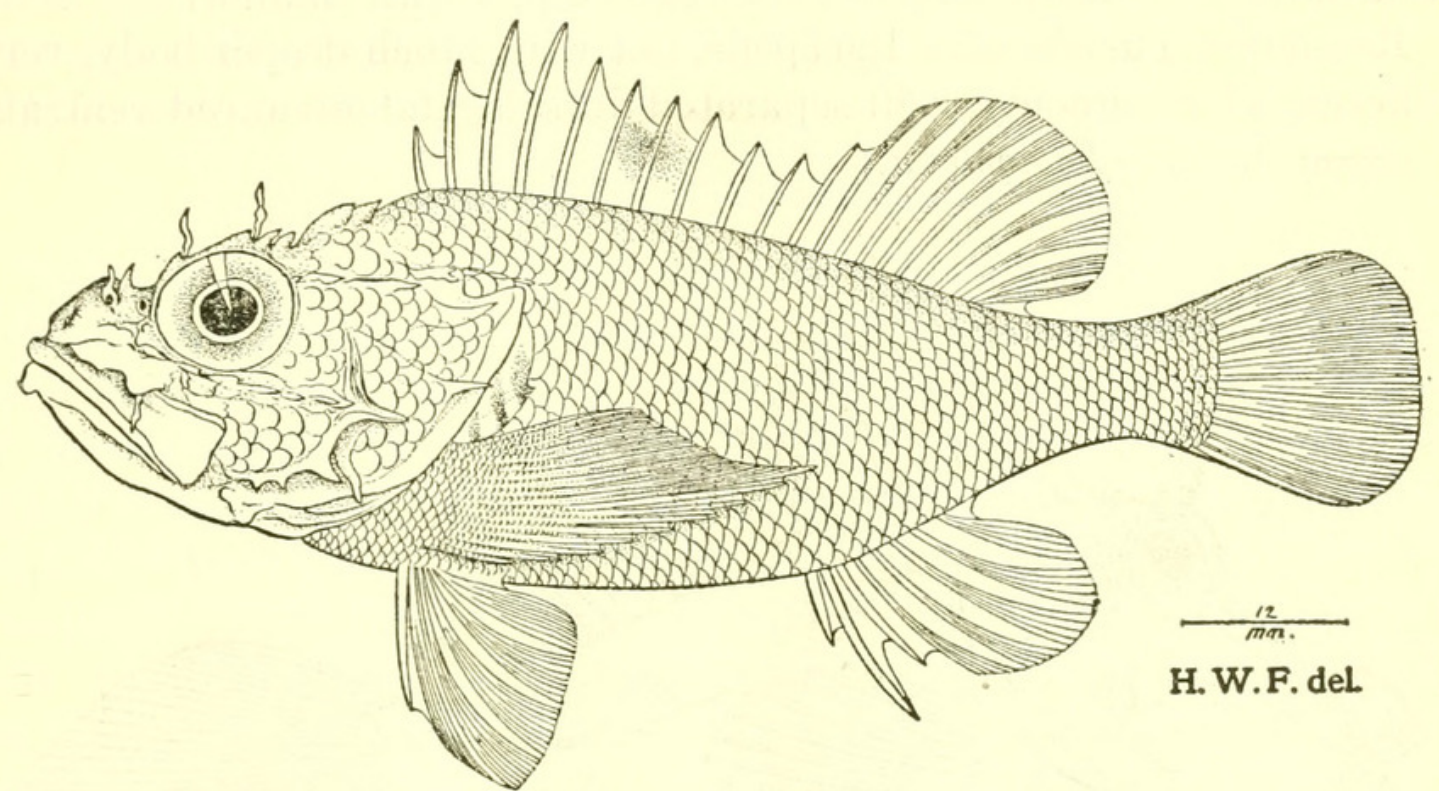

Figure 30.-Phenacoscorpius megalops, new genus, aew species. Type.

Type.-U.S.N.M. no. 98903. (3696.) D. 5387. Bagatao Island Light (outer), S. $80^{\circ}$ E., 27 miles (lat. $12^{\circ} 54^{\prime} 40^{\prime \prime}$ N., long. $123^{\circ} 20^{\prime} 30^{\prime \prime}$ E.), between Burias and Luzon. In 209 fathoms. March 11, 1909. Length $109 \mathrm{~mm}$. Also a series of paratypes, in depths from 37 to 340 fathoms.

Remarks.-Philippines, East Indies. A very distinct form, easily known by its very large eyes and incomplete lateral line, also the strong armature of the head. Several of the specimens with rather large lerneans attached to the eye. In young black dorsal spot very contrasted and extends over all membranes involved.

( $\mu \dot{\epsilon}^{\prime} \gamma a \breve{s} s$, large $+\breve{\omega} \psi$, eye.)

\section{HIPPOSCORPAENA, new genus}

Type--Hipposcorpaena filamentosa, new species.

Body deepest at hind part of head, slopes rapidly down behind. Head very large, compressed, deep, inclined forward. Snout very long, well compressed, with well concave profile, end in front as protuberance. Eye small, greatly elevated and orbital socket well 
protruded above in upper profile of head. Mouth rather small, low, lower jaw shallow and little protruded in front. Teeth obsolete. Maxillary greatly expanded behind. Interorbital deeply concave. Gill rakers short low tubercles. Scales small, smooth, adherent. Lateral line complete, axial, with rather large tubes. Head and body with skinny flaps. Fin rays simple. Two dorsals, separating notch deep and front rays of first fin highest. Anal opposite soft dorsal, base little shorter. Caudal rather long, lower rays longest. Pectoral large. Ventral inserted well before pectoral, smaller.

Resembles Taenianotus Lacépède, but with much deeper body, very different physiognomy, well-separated dorsals, and advanced ventrals.

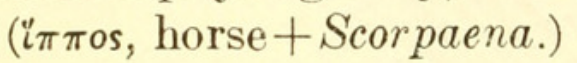

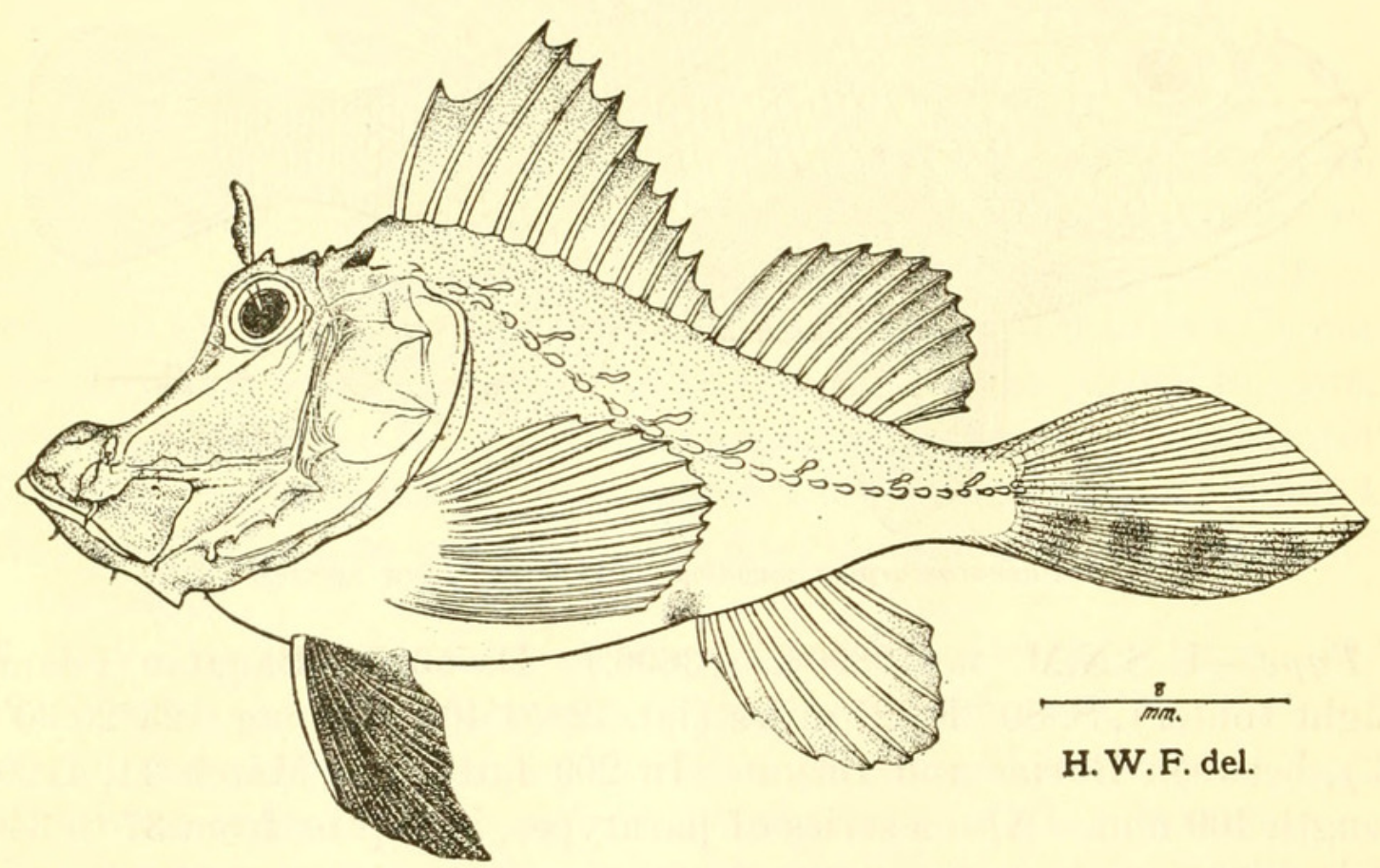

Figure 31.-Hipposcorpaena filamentosa, new genus, new species. Type.

HIPPOSCORPAENA FILAMENTOSA, new species

Figure 31

Depth $21 / 4$; head $21 / 10$, width $21 / 2$. Snout $19 / 10$ in head from snout tip; eye $6 \frac{1}{4}, 31 / 4$ in snout, greater than interorbital ; maxillary not quite reaching opposite front eye edge, expansion 3 in snout, length $24 / 5$ in head from snout tip; interorbital $11 / 5$ in eye; preopercle edge with 4 divergent spines, upper 2 largest. Gill rakers $6+11$ low spinescent tubercles, about half of gill filaments, which half of eye.

Scales about 30 counted along lateral line to caudal base; tubes 22 in lateral to caudal base and 2 more on latter; 6 scales above, 15 below. No distinct scales on head. Supraorbital flap simple, little longer than eye. Close along and above lateral line row of 8 rather long cutaneous flaps. 
D. XI, 10, second spine 2 in total head, fifth ray $23 / 4 ;$ A. 9 , fifth ray $22 / 5$; caudal $1 \frac{1}{3}$, rays branched and lower longer; least depth of caudal peduncle $47 / 8$; pectoral $13 / 5$, rays 14 ; ventral rays, I, 5 , fin $14 / 5$ in total head length.

Brown generally. Iris gray. Fins mostly paler than body, except black ventrals and lower part of caudal with longer rays. Supraocular flap dark.

Type.-U.S.N.M. no. 98819. D. 5253. Linao Point, N. $22^{\circ}$ E., 1.5 miles (lat. $7^{\circ} 4^{\prime} 48^{\prime \prime}$ N., long. $125^{\circ} 39^{\prime} 38^{\prime \prime}$ E.), Gulf of Davao. In 28 fathoms. May 18, 1908. Length $38 \mathrm{~mm}$.

(filamentosa, with filaments.)

\section{NEMAPONTINUS, new genus}

Type.-Nemapontinus tentacularis, new species.

Body well compressed, ovate. Head large, compressed. Muzzle long, conic, longer than snout. Eye little advanced from middle of head, impinging little on upper profile. Mouth large, lower jaw slightly protruding. Maxillary reaches below eye, well expanded behind. Teeth in villiform bands in jaws and on vomer, none on palatines. Armature of head prominent, spines all well developed. Gill opening large, deeply cleft, membranes divided, free. Gill rakers lanceolate. Scales small, in oblique or inclined series on body, ctenoid. Lateral line complete, axial along side of body. Dorsals united, anterior spines highest. Soft dorsal rounded. Anal with 3 spines, of which second largest. Caudal rounded convexly behind. Pectoral with deep base, rays all simple, fin rather large. Ventral moderate, inserted little before pectoral origin.

Closely related to Pontinus Poey, but differs in the very long supraorbital tentacles.

$(\nu \hat{\eta} \mu a$, thread +Pontinus. $)$

\section{NEMAPONTINUS TENTACULARIS, new species}

Figure 32

Depth $23 / 4$ to 3 ; head $1 \frac{9}{10}$ to $2 \frac{1}{10}$, width $21 / 6$ to $21 / 5$. Snout $31 / 3$ to $32 / 5$ in head from snout tip; eye $41 / 5$ to $43 / 4,11 / 4$ in snout, nearly twice as wide as interorbital; maxillary reaches $1 / 2$ to $3 / 5$ in eye, expansion $1 \frac{1}{2}$ to $14 / 5$ in eye, length $2 \frac{1}{8}$ to $21 / 6$ in head from snout tip; teeth finely villiform, in broad bands in jaws and on vomer, none on palatines; interorbital $93 / 4$ to 11 , deeply concave. Gill rakers $6+13$, moderate, of which 4 above and 6 below rudimentary tubercles; equal gill filaments or 3 in eye.

Pair of small, strong, nasal spines; pair of antero-supraorbital spines and 3 pairs of postero-supraorbital spines, followed by pair of 
well developed occipital and nuchal spines; strong postorbital spine, followed by another more posterior and close to smaller one on suprascapula; 2 preorbital spines, posterior larger and directed backward; suborbital stay with 4 spines, of which first on preorbital; 4 preopercular spines, upper largest and with small prebasal spine; 2 wide set opercular spines, larger above, opposite one another; strong humeral spine.

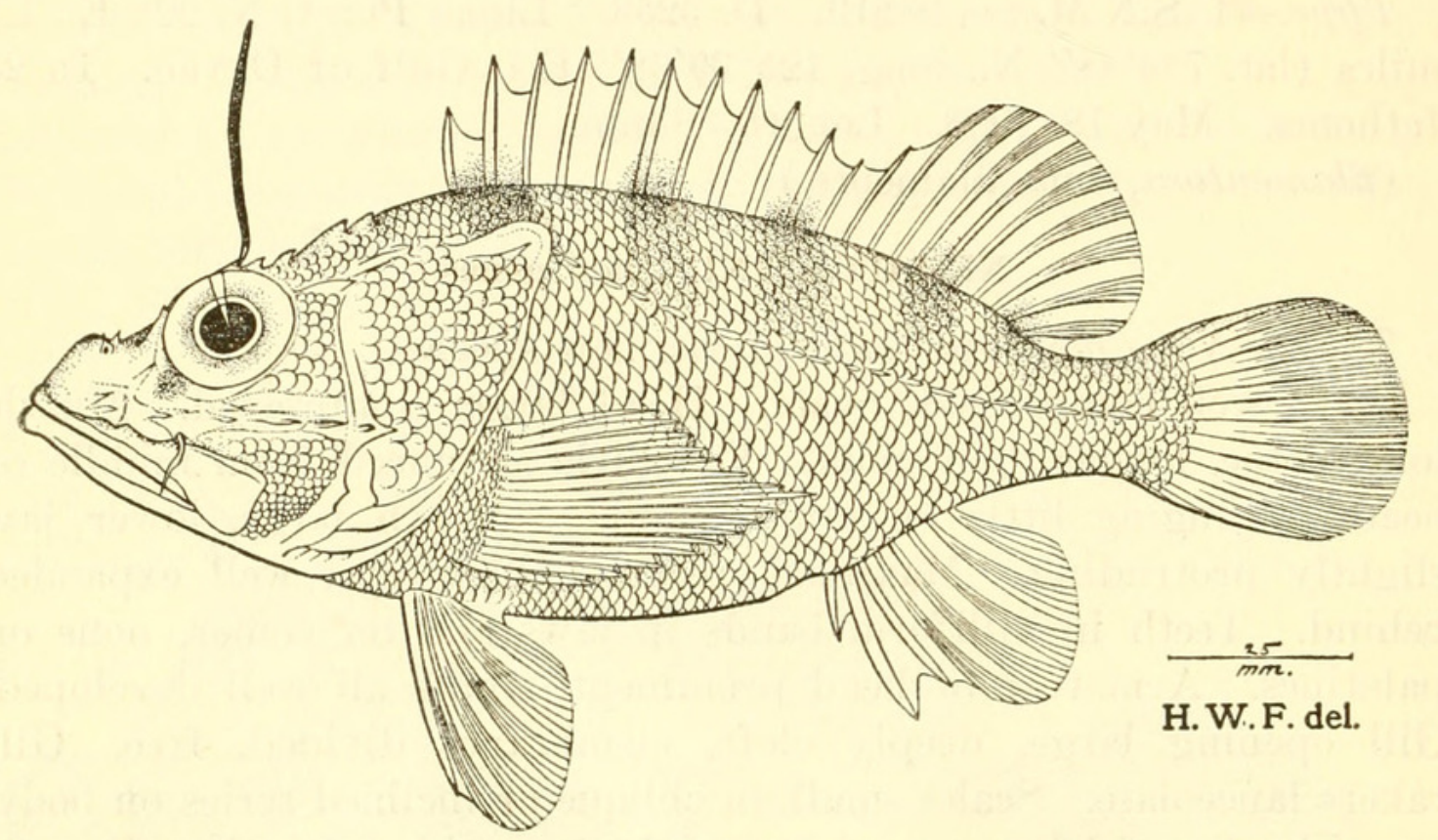

Figure 32.-Nemapontinus tentacularis, new genus, new species. Type.

Scales 42 to $45+3$ close above and along lateral line; tubular scales 23 to $29+1$ or 2 in lateral line; 8 scales above, 12 to 14 below; 14 to 17 predorsal; 3 postoculars. Scales very small on breast, chest, prepectoral region, also on caudal base. Lateral line complete, axial; tubes long, slender, simple, well exposed. Scales on cheek and postocular smaller than others on opercle and top of head, which otherwise naked. Long supraorbital filament $2 \frac{1}{5}$ in total head longth (less developed or absent in small examples). Small filament at antero-supraorbital spine, also one at each preorbital spine. Scales with 11 to 14 short marginal radiating basal striae; 48 to 50 fine apical denticles, slender, with 3 transverse series of basal elements; circuli fine.

D. XII, 9, I, fourth spine $3 \frac{1}{8}$ to 4 in total head length, fourth ray $2 \frac{1}{2}$ to $23 / 4$; A. III, 5 , I, second spine $23 / 4$ to $3 \frac{1}{5}$, second ray $2 \frac{1}{3}$ to $23 / 4$; caudal 2 , convex behind; least depth of caudal peduncle 5 ; pectoral $13 / 5$ to $17 / 8$, rays 16 ; ventral rays $I, 5$, fin $\varepsilon$ to $2 \frac{1}{10}$ in head from snout tip.

Brown, clouded obscurely with paler and darker. Five dark saddles along edge of back, but little reflected on bases of fins. Iris pale, with some grayish. Supraorbital tentacle blackish. Fins all 
pale or light brown. Some obscure brownish cloudings on spinous dorsal, especially on sixth to eighth membranes.

Type.-U.S.N.M. no. 98887. (3143.) D. 5519. Point Tagolo Light, S. $71^{\circ}$ W., 8.7 miles (lat. $8^{\circ} 47^{\prime}$ N., long. $123^{\circ} 31^{\prime} 15^{\prime \prime}$ E.), northern Mindanao and vicinity. In 182 fathoms. August 9, 1909. Length $185 \mathrm{~mm}$.

Paratypes.-U.S.N.M. no. 99008. (3231, 3232.) D. 5279. Malavatuan Island (W.), S. $18^{\circ}$ W., 5.40 miles (lat. $13^{\circ} 57^{\prime} 30^{\prime \prime}$ N., long. $120^{\circ} 22^{\prime} 15^{\prime \prime}$ E.), China Sea, vicinity of southern Luzon. In 117 fathoms. July 17, 1908. Length 158 to $168 \mathrm{~mm}$. Two examples. (tentacularis, with tentacles.)

\section{CROSSOSCORPAENA, new genus}

Type.-Sebastes hexanema Günther.

Body elongately ovoid, rather slender. Head large, pointed. Snout long, little convex in profile. Eye large, well impinging on upper profile of head, largely premedian. Mouth little inclined, lower jaw slightly projecting. Maxillary extends below eye, expanded terminally. Interorbital narrow. Teeth in jaws and on. palate. Armature of head well developed. Scales small, especially on chest, breast, and prepectoral region. Head largely scaly, muzzle naked. Few short filaments on head and row along lateral line. Dorsal continuous, spinous section with longer base though longest spines lower than soft dorsal, membrane entire, spines 12. Anal with 3 spines, shorter than rays. Caudal truncate. Pectoral small, also ventral.

Small rosy fishes of the East Indies, chiefly characterized by the row of small filaments along the entire course of the lateral line.

(кроббоi, fringe + Scorpaenx.)

\section{MACROSCORPIUS, new genus}

\section{Type.-Macroscorpius pallidus, new species.}

Body elongate, slender, moderately compressed, deepest at spinous dorsal origin. Head large, conic, elongate. Snout long, conic. Eye high, rather small, before middle in head. Mouth large, inclined little from horizontal. Jaws about equal, with broad dental area of upper jaw exposed. Mandible scarcely or not protruding, with broad bony spur at symphysis. Teeth fine, roughly granular, sharp points prickly to touch; narrow band on vomer and each palatine. Interorbital low, nearly level. Gill opening wide, but slightly joined to isthmus. Gill rakers lanceolate, moderate. Bones of head all more or less cavernous, with sharp though small and inconspicuous spines. Scales caducous, cycloid. Head largely naked. Bases of caudal and pectoral scaly. Lateral line complete, conspicuous canai, 
with large pores few in number, axial along upper side of body. Dorsals separated, membranes of spinous fin entire to ends of spines; soft fin nearly or quite high as first dorsal. Anal similar, smaller and opposite, with 2 slender spines, second larger and longer. Caudal moderate, rudimentary rays well developed. Pectoral long, reaches to or little in anal, especially in young, with broad base, simple rays nearly half number of fin rays. Ventral inserted slightly before pectoral origin, fin rather small.

Apparently differs from Lioscorpius Günther in the presence of but 2 anal spines, a character not shared by any species of Setarches. Setarches remiger (Gilbert and Cramer) differs further not only in its 3 anal spines, but also the deeper body, more dorsal spines, and the dorsal fins joined; moreover its pectoral is longer and its scales are very small.

(

MACROSCORPIUS PALLIDUS, new species

Figure 33

Depth 4 to $4 \frac{1}{5}$; head $2 \frac{1}{6}$ to $2 \frac{1}{4}$, width 2 to $21 / 3$. Snout $27 / 8$ to 3 in head from snout tip; eye 6 to $63 / 4,17 / 8$ to $21 / 5$ in snout, 1 in interorbital; orbit 4 to $5 \% 3$ in head from snout tip, $13 / 5$ to $13 / 4$ in snout; maxillary reaches $2 / 3$ to $3 / 4$ in eye, expansion $1 \frac{1}{5}$ to $11 / 4$, length $19 / 10$ to 2 in head from snout tip; bands of villiform teeth broad in jaws, narrow on vomer and palatines, with series of latter long; interorbital 6 to $63 / 5$, low, convex. Gill rakers $7+10$, of which 3 or 4 above and below rudiments; gill filaments $7 / 8$ of gill rakers which $14 / 5$ in eye.

Pair of very small, close-set nasal spines; small antero-supraorbital spines rather low each side; occipito-nuchal ridge long, fused, each ending in a small nuchal spine behind 2 postocular spines, posterior larger and above upper end of vertical preopercle edge; suprascapular spine rather large; 2 preorbital spines, both directed backward and posterior larger; suborbital stay with 1 or 2 feeble spines, ends in one behind and another little above terminal one; 5 rather short, strong, preopercular spines; 2 small divergent opercular spines, about opposite. No humeral spine.

Scales $40+4$ close above and along lateral line; tubular scales $28+3$ in lateral line; 6 scales above, 12 below; 10 predorsal forward to occiput. Cheeks, opercle and postocular scaly. Small scales on chest, breast, prepectoral and belly. Scales with 7 basal radiating striae; circuli fine.

D. X-I, $10, \mathrm{I}$, fourth spine 3 to $31 / 6$ in total head, second ray $23 / 4$ to $31 / 8$; A. II, 6 , I, second spine $43 / 4$ to 5 , third ray 3 to $31 / 5$; caudal $15 / 6$ wo $17 / 8$, slightly concave behind; least depth of caudal peduncle $61 / 8$ to 
$61 / 5$; pectoral $11 / 4$ to $11 / 3$, rays II, 14 , Ix; ventral rays I, 5 , fin $21 / 3$ to $2 \frac{1}{2}$ in total head.

Pale brownish, nearly uniform, fins all paler or nearly whitish. Iris light grayish. Peritoneum blackish.

Type.-U.S.N.M. no. 98890 . D. 5518. Point Tagolo Light, S. $64^{\circ}$ W., 8.7 miles (lat. $8^{\circ} 48^{\prime}$ N., long. $123^{\circ} 31^{\prime}$ E.), northern Mindanao and vicinity. In 200 fathoms. August 9, 1909. Length $169 \mathrm{~mm}$.

Also a series from the Philippines in 162 to 226 fathoms.

(pallidus, pale.)

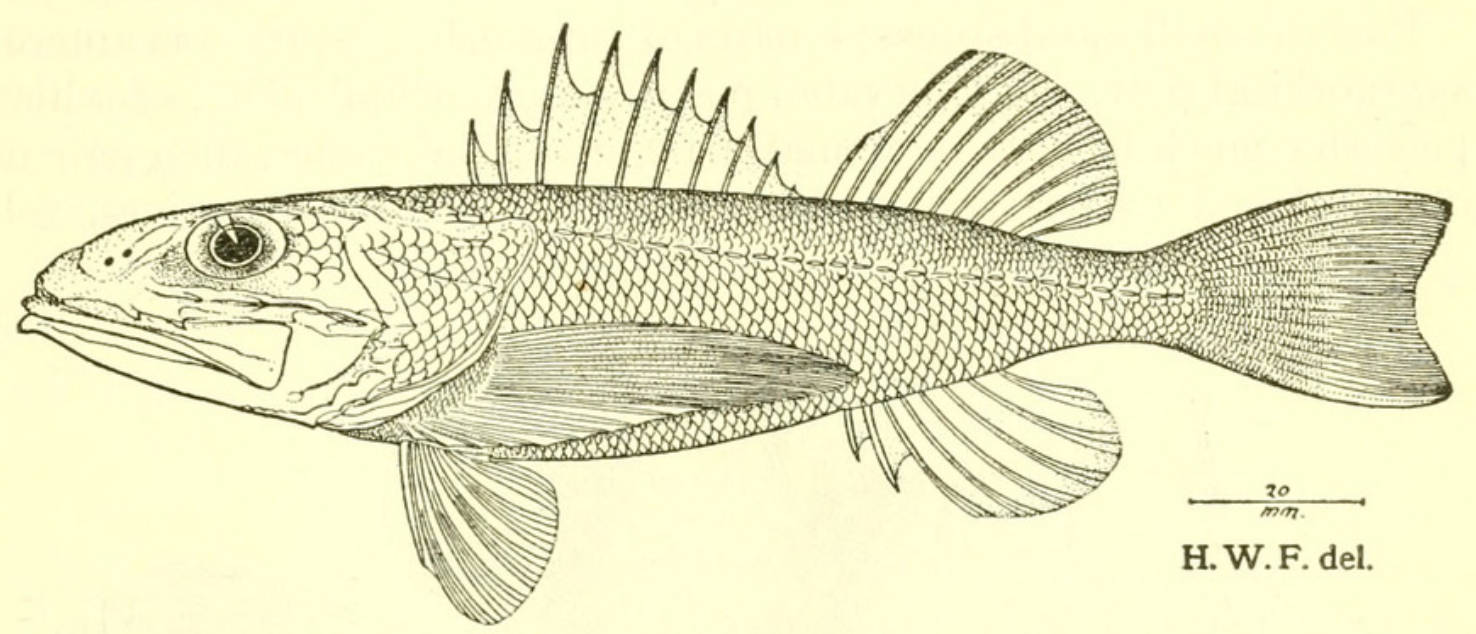

Figure 33.-Macroscorpius pa?lidus, new genus, new species. Type.

PTEROPELOR, new genus

Type.-Pteropelor noronhai, new species.

Body well compressed, ovate. Head large, well compressed, wich prominent cranial ridge. Snout compressed, deeply concave in profile, moderate. Eye moderate, elevated, well impinging on upper profile, elevated, little advanced in head. Mouth large, lower jaw protruding. Maxillary reaches below eye. Cranium with deep pit behind eyes. Spines of head distinct, not especially prominent. Gill opening wide, membranes only narrowly connected. Gill rakers tuberculate. Scales rather large, deciduous, cycloid. Lateral line distinct only anteriorly. Long supraorbital flap. Dorsals deeply notched and spinous fin higher and well set off from soft fin; each membrane of spinous dorsal at least half notched terminally. Anal like soft dorsal. Caudal elongate, rounded. Pectoral moderate, reaches into anal fin. Ventral small, inserted well before pectoral, only reaches half way in pectoral.

Somewhat with the aspect of Inimicus and also seems closer to Pterodichthys, from which it differs in its incised spinous dorsal membranes, absence of barbels, and large scales.

$$
(\pi \tau \epsilon \rho o ́ v, \text { fin }+ \text { Pelor. })
$$


Depth $27 / 8$ to 3 ; head $2 \frac{1}{8}$ to $2 \frac{1}{6}$, width 2 . Snout 3 to $31 / 10$ in head from snout tip; eye $4 \frac{1}{4}$ to $42 / 5,12 / 5$ to $1 \frac{1}{2}$ in snout, greatly exceeds interorbital; maxillary reaches $1 / 3$ to $2 / 5$ in eye, expansion $1 \frac{1}{2}$, length 2 in head from snout tip; bands of minute villiform teeth in jaws, and triangular patch on vomer, none on palatines; interorbital 6 to 7 , deeply concave. Gill rakers $6+12$, though only 6 lower developed, others as rudiments; length $3 / 5$ of gill filaments, which $2 \frac{1}{2}$ in eye.

Pair of small nasal spines; 3 pairs of supraorbital spines, as anterosupraorbital pair, and 2 elevated postero-supraorbital pairs, of which posterior much larger; very small pair of coronal spines, then pair of occipital and nuchal spines close; row of 3 postocular spines, fol-

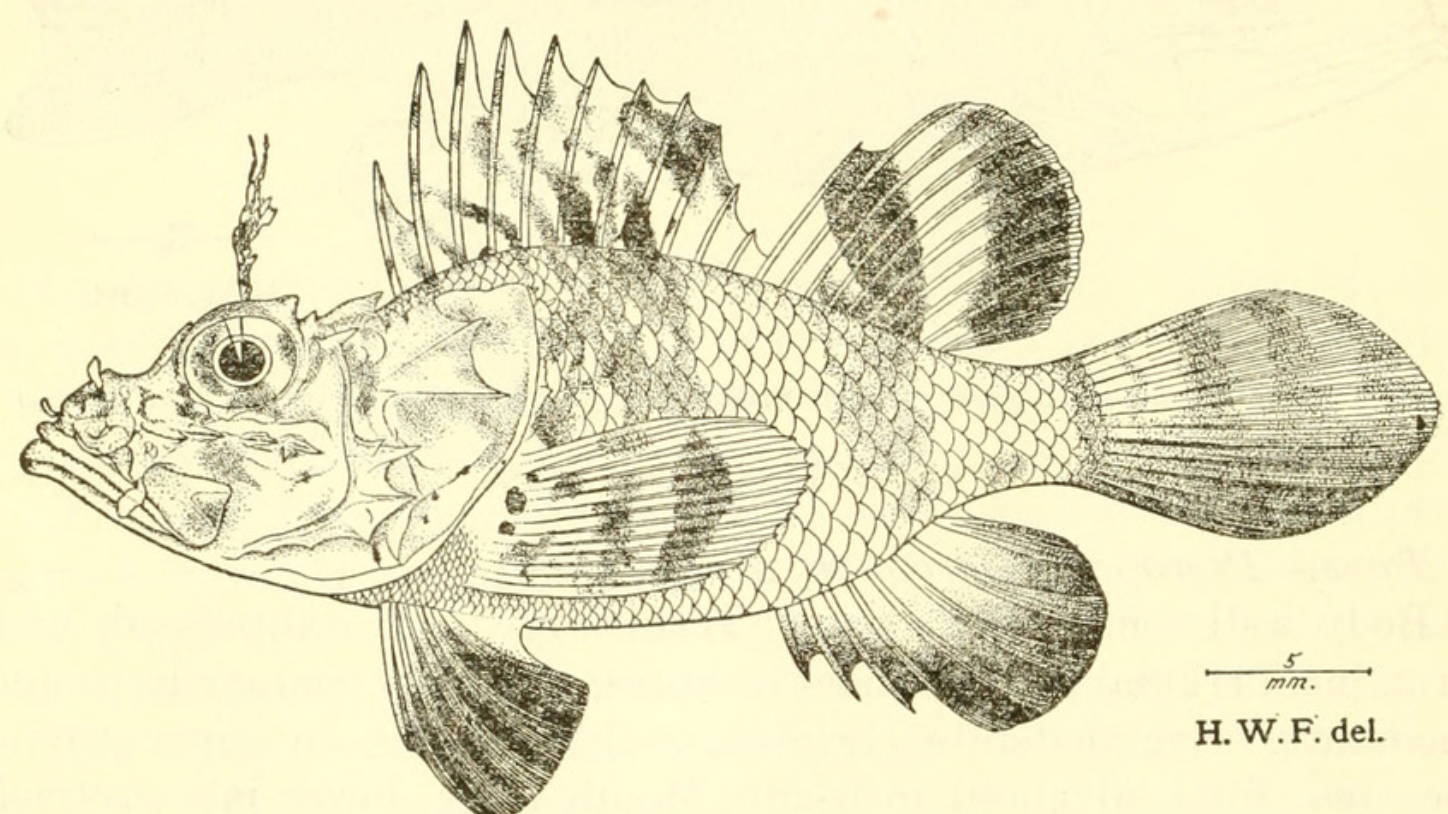

Figure 34.-Pteropelor noronhai, new genus, new species. Type.

lowed by suprascapular spine; preorbital spine directed little backward; suborbital stay with 3 spines, preceded by median preorbital spine; 4 distinct spines on preopercle edge, second below end of preorbital stay largest; 2 divergent opercular spines, opposite one another; strong humeral spine.

Scales $25+3$ along course of lateral line (as computed to caudal base); lateral line of only 5 or 6 scales anteriorly, sloping down axially and tubes long, slender, and well exposed; 4 or 5 scales above, 7 below. Head naked. Chest, breast, and prepectoral region naked. Scales small on belly. Nasal tentacle long as eye; supraorbital tentacle nearly twice long as eye; several filaments on each mandibular ramus, anterior longest; long flap to preorbital spine. 
D. XII, 9, I, fifth spine $17 / 8$ in total head length, third ray $14 / 5$ to 2 ; A. III, 5 , I, third spine $31 / 8$ to $3 \frac{1}{2}$, third ray $17 / 8$ to 2 ; caudal $11 / 3$ to $1 \frac{1}{2}$, inframedian rays longest; least depth of caudal peduncle $43 / 4$ to $4 \frac{4}{5}$; pectoral $13 / 4$, rays 15 , all simple, and membranes deeply incised terminally; ventral with spine and 5 rays, fin $13 / 5$ to 2 in total head length.

Brown, obscurely clouded darker on head above and below each dorsal on back. Spinous dorsal with membranes dark gray terminally and dark blotches basally. Soft dorsal with dark gray median blotch and terminally blackish gray. Pectoral with 2 dark brown blotches. Other fins more or less gray black terminally.

Type.-U.S.N.M. no. 98892 . D. 5310. Lat. $21^{\circ} 33^{\prime}$ N., long. $116^{\circ} 13^{\prime}$ E., China Sea, vicinity of Hong Kong. In 100 fathoms. November 4, 1908. Length $44 \mathrm{~mm}$. (688.)

Paratype.-U.S.N.M. no. 99009. D. 5310. Same data. Length 48 mm.

(For Dr. Adolfo Cesar di Noronha, of Madeira.)

\section{BRACHYPTEROIS, new genus}

Type.-Brachypterois sermlifer, new species.

Known by its short dorsal spines, shorter than soft dorsal rays. Caudal long and pointed. Long pectoral reaches near caudal base. Ventral half long as pectoral. Preorbital depth half of eye. Ridges of head serrulate, including mandible. Eye greatly longer than snout. No flaps or cirri.

Differs from Ebosia, to which it is related, in its entirely different physiognomy.

( $\beta$ a áu's, short + Pterois; with reference to the short dorsal spines.)

BRACHYPTEROIS SERRULIFER, new species

Figure 35

Depth $23 / 4$; head $2 \frac{1}{3}$, width 2. Snout $4 \frac{1}{3}$ in head from snout tip; eye $33 / 5$, much greater than snout or interorbital; maxillary reaches $2 / 5$ in eye, expansion $1 \frac{1}{3}$, length 2 in head from snout tip; bands of very minute, fine, villiform teeth in jaws, also small patch each side of head of vomer, and palatines toothless; interorbital 7, concave, with rather deep median longitudinal groove. Gill rakers 5+11, with 3 above and below rudiments; length equals gill filaments or $1 / 3$ of eye.

No nasal spines; supraorbital ridge finely serrated; parietal occipital ridge continuous, edge finely serrated; postocular ridge high, its edge serrated; lower edge of preorbital with 5 spines all directed down; ridge of suborbital stay serrated its whole length; preopercular edge with 5 rather prominent denticles, upper 2 directed back $36541-38-4$ 
and all others directed downward, also lower with several smaller or auxiliary denticles; lower inner edge of each mandibular ramus finely serrated.

Scales $40+4$ close above along lateral line; tubes $25+1$ in lateral line; 5 scales above lateral line to base of third dorsal spine, 11 below to anal origin; 15 predorsal opposite front pupil edge; 3 postocular scales; 4 obliquely back from lower eye edge to angle of preorbital stay and 8 below latter in vertical series behind maxillary; 7 rows transversely over maxillary expansion. Small scales on caudal and pectoral basally, also small on chest and breast. Scales with 10 or 11 basal radiating striae; edge with several coarse or obtuse points apically; circuli very fine, obsolete apically.

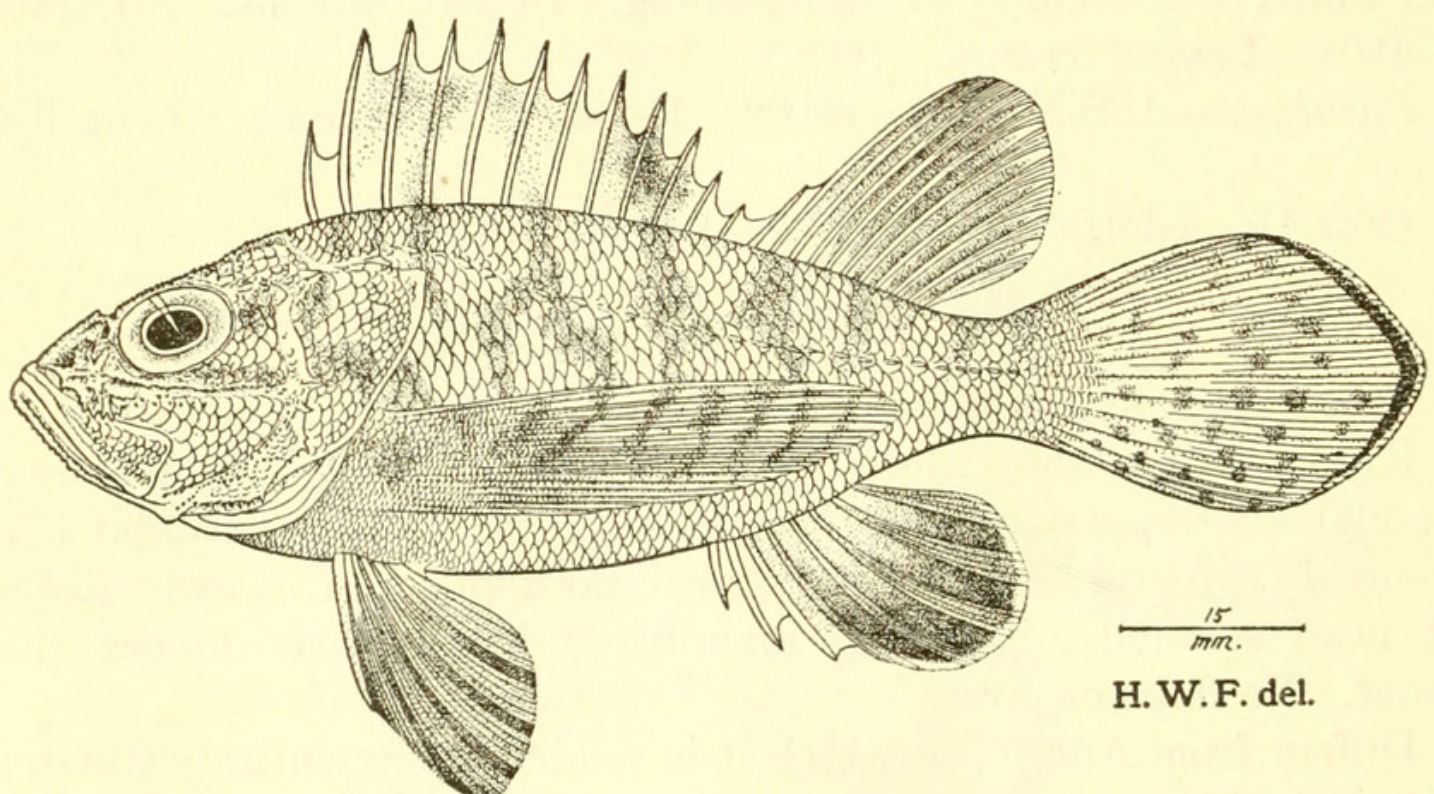

Figure 35.-Brachypterois serrulifer, new genus, new species. Type.

D. XII-I, I, 9, I, fourth spine $2 \frac{1}{4}$ in total head length and membranes apparently entire well toward tips of spines, third branched ray $13 / 4$; A. III, 5 , I, third spine $22 / 3$, third ray $14 / 5$; caudal 1 , ends in median point behind; least depth of caudal peduncle $41 / 8$; pectoral reaches $1 \frac{1}{6}$ to caudal base or its length $17 / 8$ in fish without caudal, rays II, 6 , vI; ventral rays I, 5 , fin $1 \frac{1}{2}$ in head.

Brown, with 6 darker, narrow, ill defined, transverse cross bands on back and upper sides. Three dark brown bars radiate down from eye, first at middle of lower edge, second from lower hind edge and third back over postocular. Large blackish brown blotch on opercle, nearly size of eye. Iris gray. Spinous dorsal gray marginally. Paired fins dark gray medially, on membranes, edges and rays pale to whitish. Soft dorsal, anal and caudal whitish, with some obscure gray spots terminally. 
Type.-U.S.N.M. no. 98886. (3177.) D. 5442. San Fernando Point Light, N. $39^{\circ}$ E., 8.4 miles (lat. $16^{\circ} 30^{\prime} 36^{\prime \prime}$ N., long. $120^{\circ} 11^{\prime} 6^{\prime \prime}$ E.), west coast of Luzon. In 45 fathoms. May 10, 1909. Length $115 \mathrm{~mm}$.

(sermula, a little tooth + fero, to bear.)

\section{NEMAPTEROIS, new genus}

Type.-Nemapterois biocellatus, new species.

Known by its extraordinary long preorbital barbel. Dorsal spines moderate. Pectoral moderately long. Each dorsal spine with greater terminal part free, expanded before and behind and main part of spine forming distinct midrib.

$(\nu \tilde{\eta} \mu a$, thread + Pterois. $)$

NEMAPTEROIS BIOCELLATUS, new species

FIgURE 36

Depth $23 / 4$; head $22 / 5$, width 2. Snout $3 \frac{1}{4}$ in head from snout tip; eye 3 , greater than snout, over twice width of interorbital; maxillary reaches $1 / 4$ in eye, expansion $11 / 2$ in eye, length 2 in head from snout tip; bands of minute villiform teeth in jaws and on vomer, none on palatines; interorbital $21 / 2$ in eye, very deeply concave. Gill rakers $4+11$, compressed, low, short, half of gill filaments, which $1 / 3$ of eye.

No nasal spines; low antero-supraorbital spine each side, and pair of higher postero-supraorbital spines each side, followed by pair of rather wide set coronal spines, then strong close-set parietal and occipital pairs (right parietal spine atrophied) ; low postocular keel over preopercle ends in small point, followed by another over opercle and finally suprascapular spine; ridge of suborbital stay without distinct spines; no preorbital spines; preopercle edge with 3 spines, short, obtuse, upper largest and opposite end of ridge of suborbital stay; opercle with single rather large spine; no humeral spine.

Scales $41+2$ close above along lateral line; tubes $23+1$ in lateral line; 6 scales above lateral line, 14 below; 14 predorsal forward to middle of interorbital; 2 postocular to preopercle ridge; 8 below ridge of preorbital stay on cheek. Scales small and crowded on chest, breast, prepectoral, belly, and bases of pectoral and caudal fins. Anterior nostril with pointed, fringed tentacle. Short lobate supraorbital flap behind second postero-supraorbital spine; broad flap above uppermost preopercular spine and several others below along preopercular edge. Short preorbital flap anteriorly, followed by long tentacle reaching back opposite pectoral origin. No flaps on fins or along lateral line. Lateral line complete, distinct, 
little high at first, nearly axial along side of body; tubes large, simple. Scales with 8 to 14 basal radiating striae; 26 to 32 apical denticles; circuli fine, coarser or abruptly terminated apically.

D. XIII, I, 8, I, sixth spine $12 / 5$ in total head length, second branched ray $19 / 10 ;$ A. III, 5 , I, third spine $17 / 8$, first ray $1 \frac{1}{2}$; caudal $12 / 5$, convex behind; least depth of caudal peduncle $3 \frac{1}{3}$; pectoral reaches $1 \frac{1}{3}$ to caudal or $2 \frac{1}{10}$ in fish without caudal, rays III, 7 , Ix; ventral rays $I, 5$, fin $1 \frac{1}{6} 6$ in total head length.

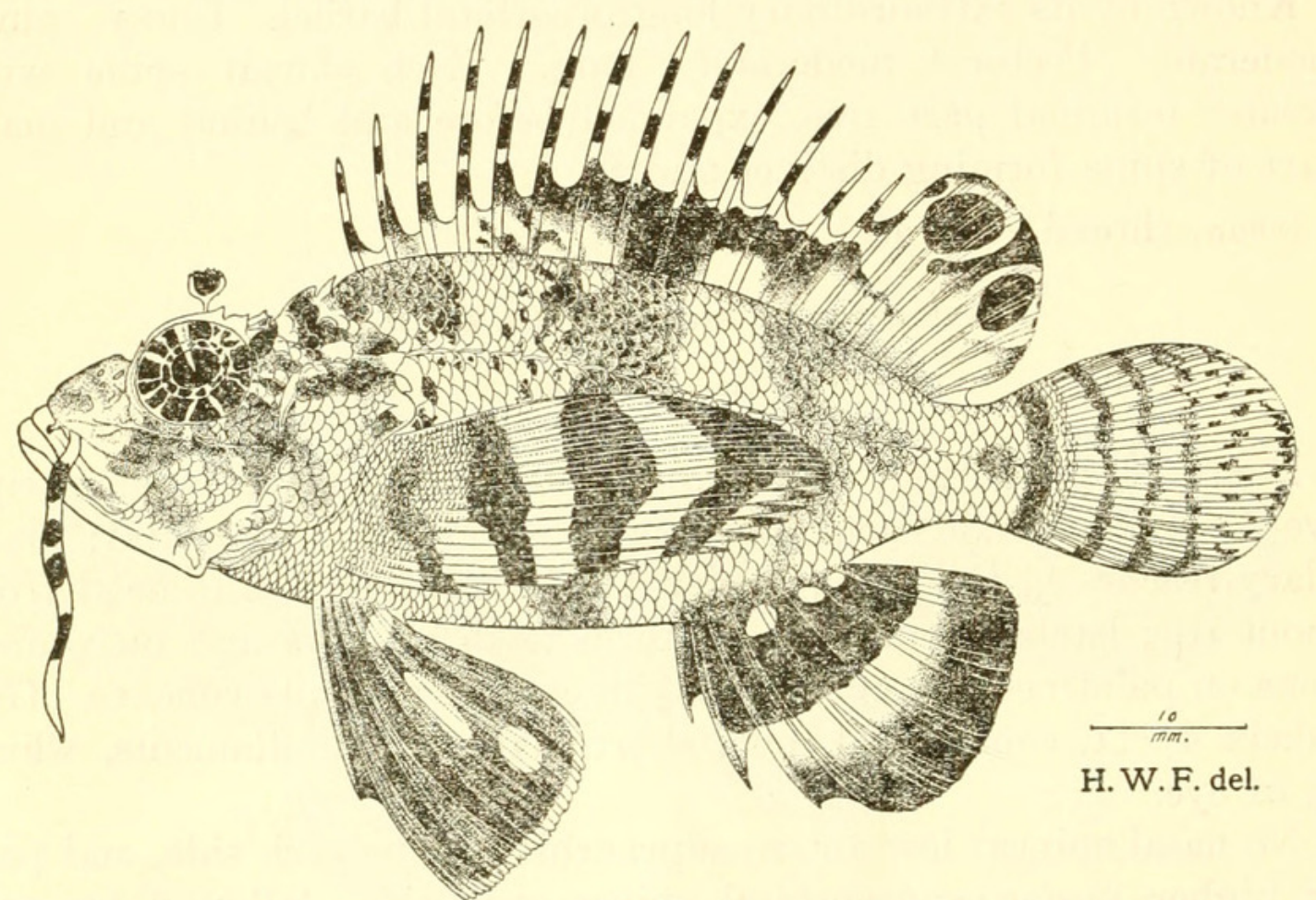

Figure 36.-Nemapterois biocellatus, new genus, new species. Type.

General tint dull flesh color to light pink. Brown blotch on front of snout, followed by broad, white band from front of eye down to maxillary. Brown bar down from lower eye edge to maxillary expansion and another posteriorly down to lower part of opercle and subopercle, interval of lower cheek lighter brown. Obscure narrow brown bar crosses lower surface of head from each side behind end of maxillary. Dark band across front of interorbital and another broader over its median area. White lines radiate in orbit from iris. Supraorbital flap white, with round black spot in expansion. Two dark brown bands, narrowly separated, cross postocular part of head and posteriorly just before dorsal a third broader one, last reflected down behind opercular spine. From middle of spinous dorsal broad blackish brown band down to belly and another from soft dorsal base to anal; these bands all reflected on bases of dorsals to join dark areas on fins, also last reaches anal. Dorsals white, spinous fin with 3 longitudinal dark brown bands, with upper 2 series marked 
as dark bars on free portions of spines; on soft dorsal lowest band continued only as subbasal obscure narrow streak. Two large black, white edged ocelli on outer part of soft dorsal, upper little larger or slightly smaller than orbit. Anal blackish brown with median white band and posterobasally fin also pale. Caudal white, with dark transverse basal band and 5 transverse dark brown narrow bands, made up of series of spots or short bars only on rays. Pectoral white, with 4 black transverse bands. Ventral black, edged anteriorly and below narrowly with white and 2 white spots in posterior part of fin. Preorbital tentacle white, with 4 black bars.

Type.--U.S.N.M. no. 98894. (2072.) D. 5136. Jolo Light, S. $37^{\circ}$ E., 0.70 mile (lat. $6^{\circ} 04^{\prime} 20^{\prime \prime}$ N., long. $120^{\circ} 59^{\prime} 20^{\prime \prime}$ E.). February 14, 1908. Depth 22 fathoms. Length $83 \mathrm{~mm}$.

Characters expressed in the genus readily distinguish the species. (bis, two +ocellus, eyelike spot.)

\section{SCORPAENELLA, new genus}

Type.-Scorpaenella cypho, new species.

Body deeply ovoid, compressed, with back well elevated anteriorly. Head large, compressed. Snout short, obtuse. Eye large, before middle in length of head, scarcely impinging on upper profile. Mouth large, little inclined and lower jaw scarcely projects. Maxil-

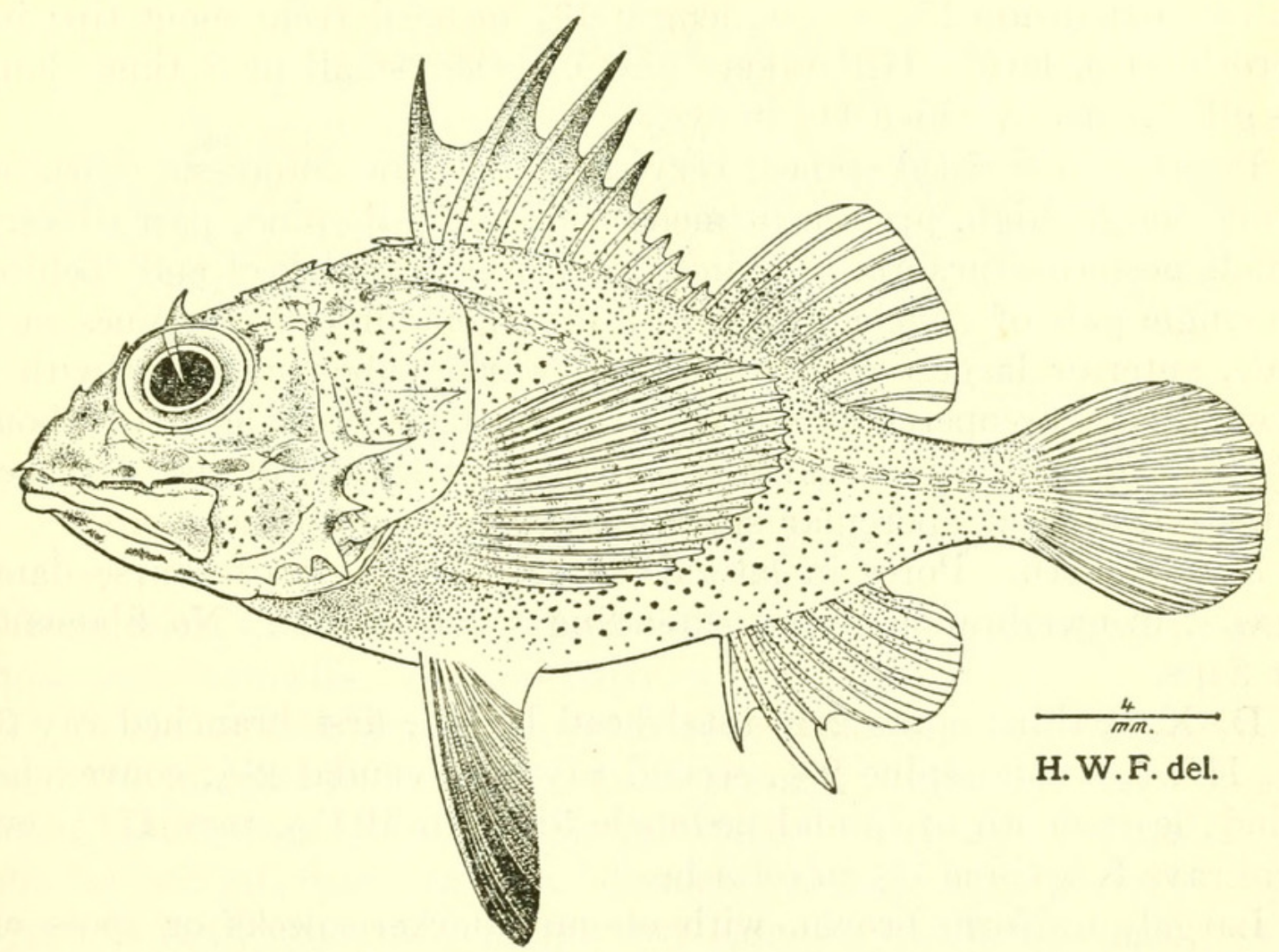

Figure 37.-Scorpaenella cypho, new genus, new species. Type. 
lary reaches below eye, expanded posteriorly. Teeth minute, villiform, in narrow bands in jaws, apparently present on vomer, but none on palatines. Interorbital low. Spines of head well developed, some quite long and conspicuous. Gill openings wide, membranes free and separate. Gill rakers slender, lanceolate, rather long. No scales. Lateral line complete, prominent, its course rather high. Dorsal spines elevated and fin well notched or separated from soft dorsal, also each membrane between spines deeply incised terminally. Soft dorsal posterior, about half size of spinous fin. Anal opposite soft dorsal, similar, smaller, with 3 spines, second longest and first longer than third. Caudal rounded. Pectoral large, with broad base, simple rays slender and well united by membranes. Ventral inserted opposite pectoral origin, with long spine.

A genus of small scorpaenoids suggestive of Lythrichthys and Pterodichthys, but with entirely different physiognomy and without any scales.

(Scorpaenella, diminutive of Scorpaena.)

\section{SCORPAENELLA CYPHO, new species}

\section{Figure 37}

Depth $22 / 5$; head $21 / 4$, width $17 / 8$. Snout 4 in head from snout tip; eye 4 , equals snout, greater than interorbital; maxillary reaches $1 / 2$ in eye, expansion $17 / 8$ in eye, length $13 / 4$ in head from snout tip; interorbital 5, level. Gill rakers $3+10$, rather small or 3 times long as gill filaments, which $1 \frac{1}{2}$ in eye.

Pair of small nasal spines; very small and low antero-supraorbital spine; large, high, prominent medio-supraorbital spine; pair of very small postero-supraorbital spines; occipital-nuchal keel ends behind in single pair of (nuchal) spines; 3 divergent preorbital spines each side, anterior largest and directed forward; suborbital stay with 3 low spines; preopercular spines 5, upper largest on head or about $13 / 5$ in eye; single postocular spine and 1 at suprascapula; 2 rather widely divergent opercular spines, lower little posterior.

Skin smooth. Pores in lateral line 21 (last part of course damaged), in membranous canal extending whole course. No filaments or flaps.

D. X, 9, third spine 2 in total head length, first branched ray 3 ; A. III, 5 , second spine $2 \frac{3}{3}$, second ray $31 / 5$; caudal $21 / 5$, convex behind; least depth of caudal peduncle 5 ; pectoral $11 / 3$, rays 17 ?; ventral rays $\mathrm{I}, 5$, spine $14 / 5$ in total head.

Largely uniform brown, with obscure darker specks or spots on trunk and tail. Iris grayish. Fins pale. Ventral rays darker terminally. 
Type.-U.S.N.M. no. 98899. D. 5618. March Island, S. $69^{\circ}$ E., 7.8 miles (lat. $0^{\circ} 37^{\prime} 0^{\prime \prime}$ N., long. $127^{\circ} 15^{\prime} 0^{\prime \prime}$ E.), Molucca Passage. In 417 fathoms. November 27,1909 . Length $27 \mathrm{~mm}$.

(кӣфós, hunchbacked.)

\section{Genus INIMICUS Jordan and Starks}

According to Jordan and Starks this genus differs from Pelor chiefly in the absence of long filamentous tips to the upper rays of the pectorals. The head is also more depressed and of slightly different shape. Evidently the two species they admit are referable to only one, Inimicus aurantiacus, differing chiefly in its orange color, or blackish tinged with orange, but without distinct cross bands.

\section{INIMICUS BIFILIS, new species}

Figure 38

Depth 4 ; head $23 / 4$. Snout $22 / 5$ in head from snout tip; eye $51 / 5$, $21 / 5$ in snout; maxillary reaches $2 / 3$ to eye, expansion $1 \frac{1}{4}$ in eye; length in profile $3 \frac{1}{5}$ in head from snout tip; interorbital narrow, deeply concave, width about equals eye.

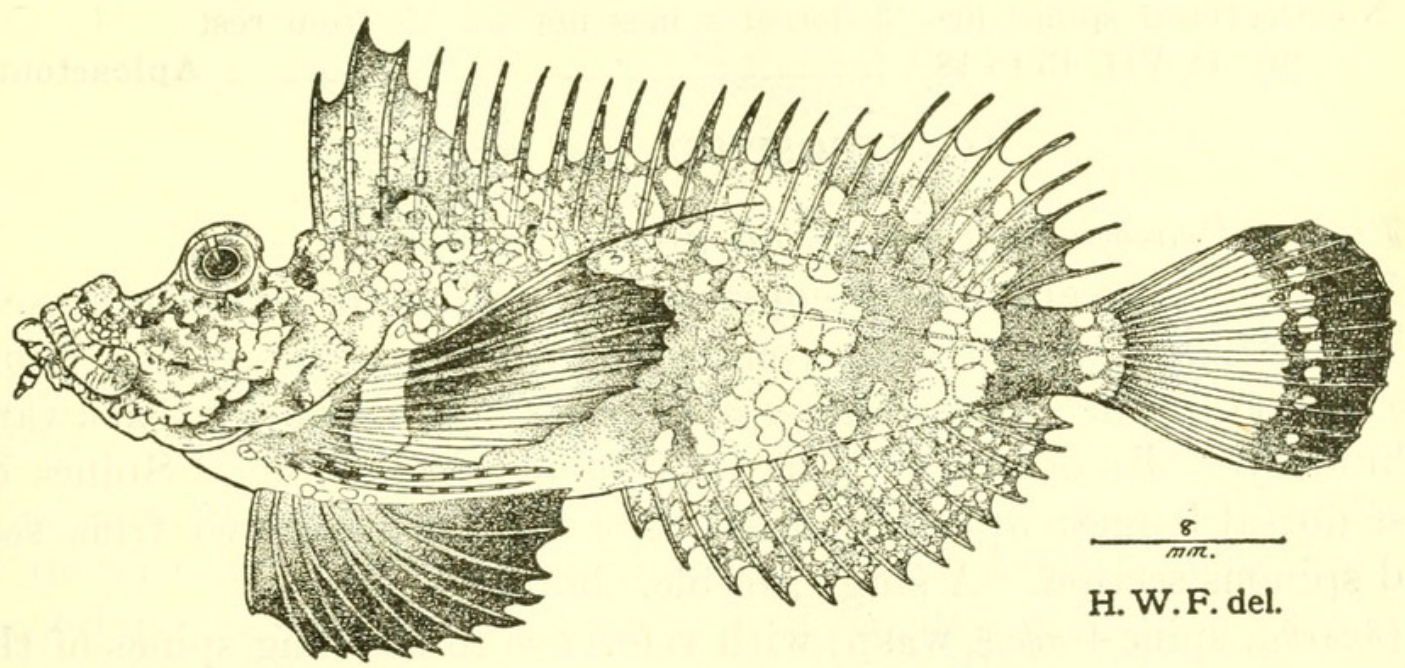

FIGURE 38.-Inimicus bifilis, new species. Type.

Body with smooth skin. Head with many irregularities, ridges, knobs, and caruncles. Several flaps on mandible.

D. XVII, 8, first spine inserted at first third in postocular, second spine $17 / 8$ in total head length, third ray $17 / 8$; marginal ends of all dorsal membranes deeply cleft; A. 13 , fifth ray $21 / 5$; caudal $12 / 5$, rounded behinr; least depth of caudal peduncle $44 / 5$; pectoral $11 / 2$, rays I, 3, VI-II, uppermost simple ray elongate, filiform, reaches $14 / 5$ to caudal; ventral I, 5 , fin length $11 / 5$ in total head length, last ray broadly adnate by membrane with belly. 
Brown, paler below and with 3 pale transverse diffuse areas on body. Fins more or less brownish. Dorsals and anals, also head and body, with obscure pale to whitish spots and blotches, very variable. Caudal blackish on outer portion, with row of small whitish spots transversely. Pectoral with broad white subbasal band, adjoining blackish area over branched rays and another terminally; lower detached rays with dark spots. Ventral blackish, little paler basally.

Type.-U.S.N.M. no. 98905. (22403.) Canmahala Bay. March 11, 1909. Length $57 \mathrm{~mm}$.

Remarks.-Greatly like Inimicus filamentosus, but only the uppermost pectoral ray ending in a filament, which reaches well beyond the depressed pectoral fin.

(bis, two + filum, thread.)

\section{Family APLOACTIDAE}

\section{ANALYSIS OF GENERA}

$a^{1}$. Preorbital with 2 strong spines both projecting back behind eye; A. I, 7 ; ventral I, 2

Acanthosphex

$a^{2}$. Preorbital with single strong spine; A. spines III; ventral I, 4 or 5 Prosopodasys

$a^{2}$. No preorbital spine; first 3 dorsal spines not set off from rest of fin; D. VII, 15 to 18

Aploactoides

\section{ACANTHOSPHEX, new genus}

Type-Prosopodasys leurynnis Jordan and Seale.

Body elongate ellipsoid, compressed. Head moderate, compressed. Fine teeth in jaws and on vomer, none on palatines. Two short barbels at chin. Suborbital spines long, both project backward behind eye. Preopercular spines all enlarged and long. Spines of first dorsal longest of dorsal series, first fin also separated from second spinous section. A single, feeble, short anal spine.

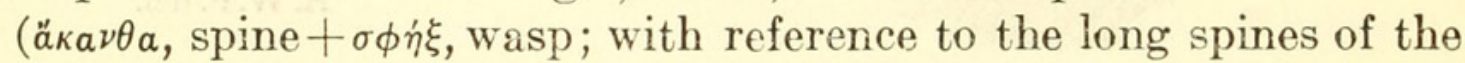
head.)

\section{Genus PROSOPODASYS Cuvier}

PROSOPODASYS CYPHO, new species

FIgure 39

Depth $2 \frac{1}{2}$; head $2 \frac{1}{2}$, width 2 . Snout 4 in head from snout tip; eye 4, subequal with snout, greater than interorbital; maxillary reaches $1 / 2$ in eye, expansion $1 \frac{1}{3}$ to $1 \frac{1 / 2}{2}$, length 2 in head from snout tip; patch of finely villiform teeth on vomer and each palatine; interorbital $5 \frac{1}{2}$, moderately low, depressed or slightly concave; subopercular and uppermost preopercular spine subequal or $1 / 2$ of eye; 
preopercular spines 4. Gill rakers $3+7$, short weak points, $1 / 3$ of gill filaments, which $1 / 2$ of eye.

Body covered with minute, close set, firmly adherent non-imbricate scales. Lateral line high, axial, incomplete on caudal peduncle, of 18 or 19 rather long, simple tubes.

D. III, X, 8 insertion of first spinous dorsal over hind eye edge, length $1 / 2$ in space to end of second depressed spine, which $17 / 8$ in total head, third ray $14 \frac{4}{5}$; A. III, 5 , third spine $22 / 5$, third ray $17 / 8$; caudal $1 \frac{2}{5}$, rounded behind; depth of caudal peduncle $3 \frac{1}{2}$; pectoral 1 , rays $I, 11$; ventral rays $I, 5$, fin $13 / 5$ in total head length.

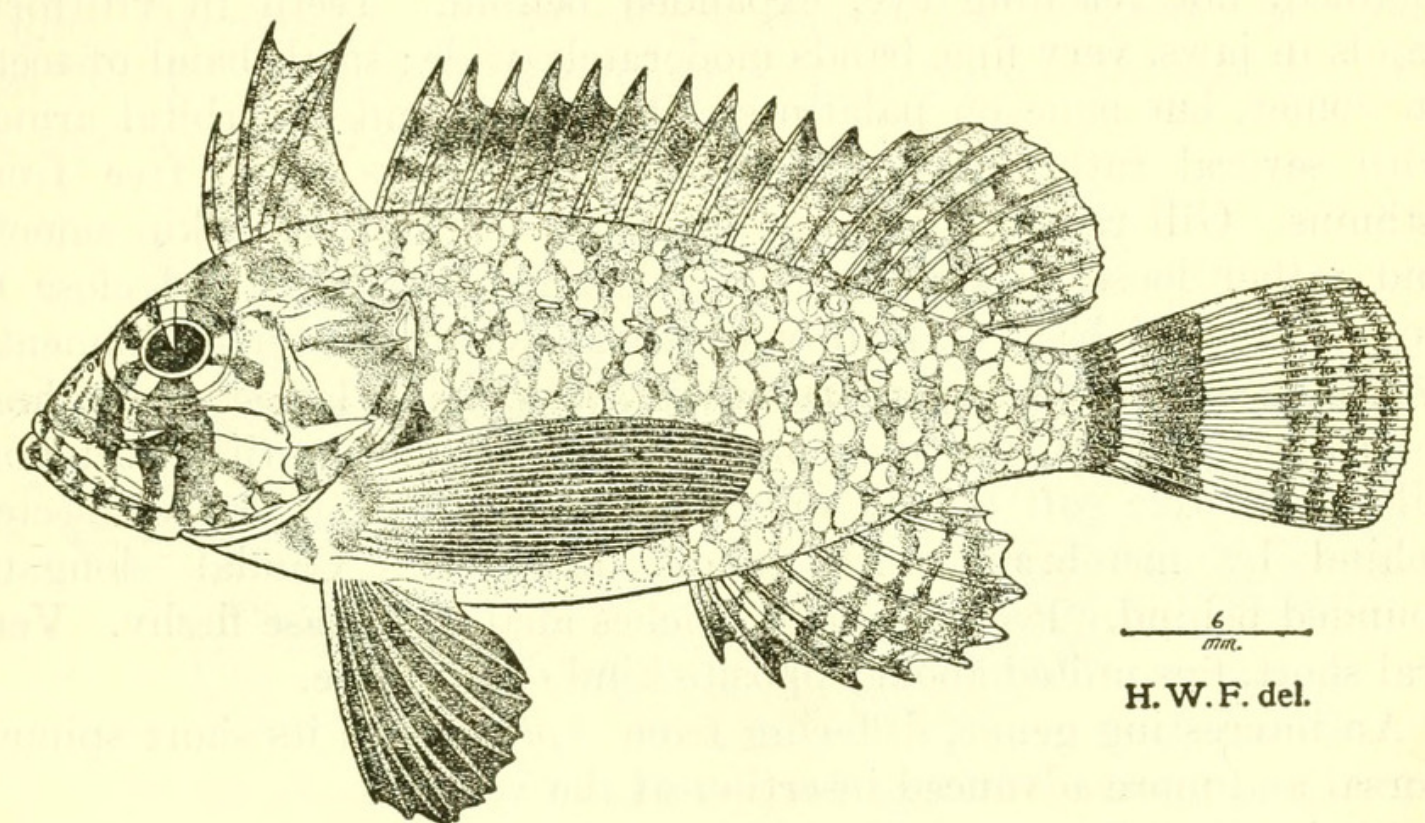

Figure 39.-Prosopodasys cypho, new species. Type.

Brown, stightly paler on head and belly below. Head with broad, whitish frontal band, one down from front of eye over maxillary expansion, another from hind eye edge over cheek and vertical limb of preopercle. White bar at pectoral base. Dorsals dark brown. Second dorsal with whitish longitudinal streak subbasal, above which on middle of fin from fifth to ninth spines broad blackish brown blotch. Soft dorsal with darker brown transverse waved lines or bars. On anal 3 or 4 broad, slightly darker iransverse bands. Caudal with 2 brown bands crosswise, fin with posterior broader dark basal bar and 4 terminal waved dark transverse lines of bands intervening pale areas whitish. Paired fins blackish brown.

Type.-U.S.N.M. no. 98902. (19707.) Davao, Mindanao. May 16, 1908. Length $45 \mathrm{~mm}$.

Remarks.-Distinguished by its elevated back, coloration, and proportions. It differs from Prosopodasys trachinoides as figured by 
Bleeker in the dorsal origin over the hind eye edge; it is also quite different from both $P$. zollingeri and $P$. trachinoides in coloration.

( $\kappa \bar{v} \phi o ́ s, ~ h u n c h b a c k e d$.

\section{APLOACTOIDES, new genus}

\section{Type.-Aploactoides philippinus, new species.}

Body elongate, well compressed, tapers back from head. Head rather small, compressed. Snout short, obtuse. Eye small, advanced until nearly before center in head length, high. Mouth small, broad, nearly vertical, opens upward. Maxillary very greatly inclined, not reaching eye, expanded behind. Teeth in villiform bands in jaws, very fine, bands moderately wide; small band of teeth on vomer, but none on palatines. Preopercle and preorbital armed with several rather long spines. Gill openings wide, free from isthmus. Gill rakers short, low tubercles or papillae. Skin smooth and rather loose, at least on fins. Lateral line high and close to upper edge of back. Head with short, small scattered filaments. Dorsal begins over hind part of eye, first spine larger than those immediately following, and spinous fin much shorter than soft dorsal. Anal like soft dorsal, only little smaller, both fins connected behind by membrane with caudal peduncle. Caudal elongate, rounded behind. Pectoral long, reaches anal, low, base fleshy. Ventral short, fins united about opposite hind edge of eye.

An interesting genus, differing from Aploactis in its short spinous dorsal and more advanced insertion of the ventrals.

(Aploactis $+\epsilon i \delta \delta$, resemblance.)

\section{APLOACTOIDES PHILIPPINUS, new species}

\section{Figure 40}

Depth 3 to $31 / 2$; head $32 / 3$ to $33 / 4$, width $11 / 2$ to $13 / 5$. Snout $31 / 2$ to 4 in head from snout tip; eye 5 to $51 / 5,12 / 5$ to $1 \frac{1}{2}$ in snout, $1 \frac{1}{4}$ to $1 \frac{1}{2}$ in interorbital; orbit 4 to $43 / 4$ in head from snout tip, equals snout, 1 to $1 \frac{1}{5}$ in interorbital; maxillary extends $1 / 2$ to $3 / 5$ in snout, expansion $11 / 5$ to $1 \frac{1}{2}$ in eye, length $21 / 3$ to $22 / 5$ in head from snout tip. Gill rakers as $6+10$ low papillae, barely $1 / 6$ of gill filaments, which equal eye.

Two strong, divergent preorbital spines, posterior much longer and equal eye; 4 preopercular spines, uppermost longest or equal eye. Few short filaments on chin.

Skin smooth, flabby, or rather loosely investing fins. Many fine, short, cutaneous points or flaps on head. Lateral line high, extends along upper part of back, with 14 pores, and apparently reaches to base of last dorsal ray. 
D. VII, 15 to 18 , first spine inserted over hind part of eye, $2 \frac{1}{4}$ to $27 / 8$ in total head length, tenth ray $1 \frac{2}{5}$ to $13 / 5$; A. II, 14 or 15 , spines rather short, eighth ray $14 / 5$ to 2 ; last dorsal and anal rays adnate to caudal peduncle; depth of caudal peduncle 3 ; pectoral 1 in head to $11 / 8$ times head, rays 14 or 15 ; ventral rays $I, 2$, length 2 to $21 / 4$ in total head length.

Brown generally, mottled or shaded little darker on head and back and also fins, which blackish brown submarginally with edges of rays all very narrowly whitish and in contrast. Small black dots, irregular and variable, scattered over trunk, tail, and fins.

Type-U.S.N.M. no. 98880. (3753.) D. 5504. Macabalan Point Light (Mindanao), S. $39^{\circ}$ E., 6 miles (lat. $8^{\circ} 35^{\prime} 30^{\prime \prime}$ N., long. $124^{\circ} 36^{\prime}$ E.), northern Mindanao and vicinity. In 200 fathoms. August 5, 1909. Length $119 \mathrm{~mm}$.

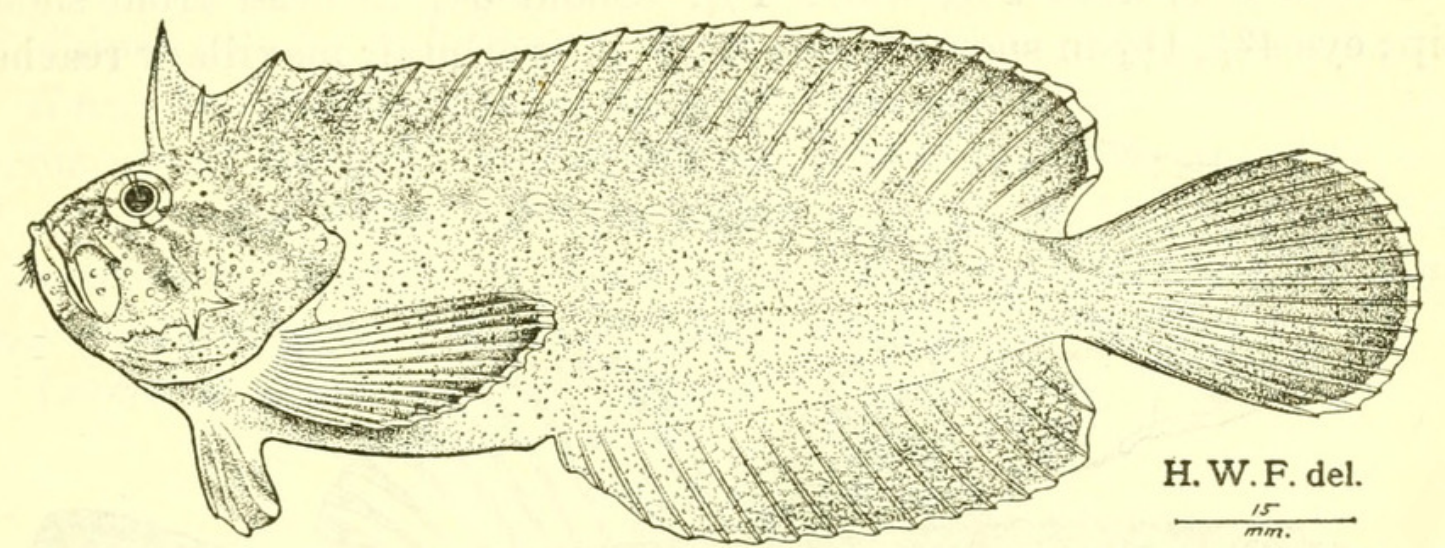

Figure 40.-Aploactoides philippinus, new genus, new species. Type.

Also a series paratypes, all from the Philippines, in 179 to 217 fathoms.

(Named for the Philippines.)

\section{Family PLATYCEPHALIDAE}

GRAMMOPLiTINAE, new subfamily

Type genus, Grammoplites Fowler.

Each scale of lateral line with a strong spine, continuous its entire length.

\section{CymbaCephalinae, new subfamily}

Type genus, Cymbacephalus, new genus.

Conspicuous pit at hind orbital edge. Several supraorbital tentacles and one at front nostril. Two subequal preopercular spines. 


\section{CYMBACEPHALUS, new genus}

Type.-Platycephalus nematophthalmus Günther.

Head moderately depressed, with strong ridges and high sharp spines. Teeth in jaws and on palate fine or villiform, without canines. Vomerine teeth in 2 parallel bands. Palatine teeth in band. One enlarged preopercle spine. Head largely scaly. Soft dorsal and anal with membranes entire.

Distinguished chiefly by a large deep pit behind each eye. Eye with large branched, supraorbital tentacle.

$(\kappa \dot{v} \mu \beta \eta$, cavity $+\kappa \epsilon \phi \bar{a} \lambda \dot{\eta}$, head.)

CYMBACEPHALUS ARMATUS, new species

Figure 41

Depth $61 / 2$; head $27 / 8$, width $1 \frac{1}{4}$. Snout $33 / 4$ in head from snout tip; eye $42 \frac{1}{3}, 1 \frac{1}{4}$ in snout, 5 times bony interorbital; maxillary reaches

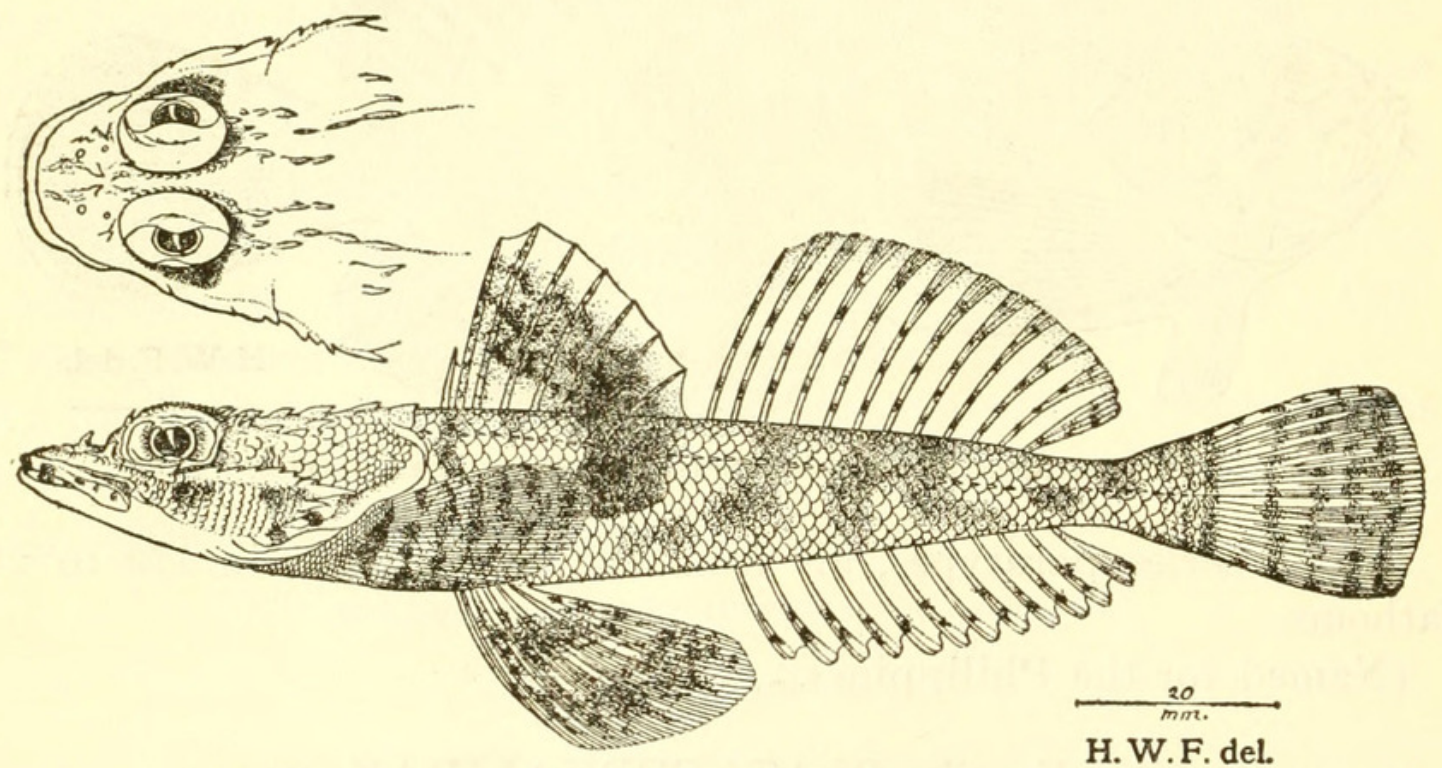

Figore 41.-Cymbacephalus armatus, new genus, new species. Type.

very slightly beyond front eye edge, length $31 / 3$ in head from snout tip; interorbital narrow, depressed. Gill rakers?

Anterosupraorbital spine, followed by row of uniform supraorbital close set denticles of which last 2 posterior enlarged, then pair of frontal spines, pair of parietals and pair of occipitals; 3 postocular spines, 3 above opercle and 2 suprascapulars; pair of strong close set nasal spines, one erect preorbital and suborbital stay with 8 spines, last or preopercular longest, with 2 more on preopercle below; 2 opercular spines.

Scales 46 in lateral line to caudal base and 4 more on latter, unarmed; 5 scales above, 12 below. Very small scales on prepectoral region and breast. Iniraorbital and cheek with small close set scales. Opercular scales moderate, smaller posteriorly. Caudal base scaly. 
D. VIII-I, 12 , I, third spine $21 / 10$ in total head length, first branched ray $19 / 10$; A. 12 , I, third ray $3 \frac{1}{4}$; caudal $13 / 4$, convex behind; least depth of caudal peduncle $61 / 4$; pectoral 2 , rays 20 ; ventral $1 \frac{1}{4}$, rays, I, 5 .

Body brown, paler below. Several dark blotches on body, with large one on back below hind part of spinous dorsal. Three dark blotches below soft dorsal. Spinous dorsal with broad dark oblique band sloping back and joining dark saddle on back. Each ray of soft dorsal with 4 or 5 dark spots. Caudal with 4 or 5 irregular transverse rows of dark spots. Anal pale, with one or two dark spots on each ray terminally. Pectoral with 7 dark cross bars. Ventral with 2 broad dark bands transversely. Several dark spots on lips and others on cheek.

Type--U.S.N.M. no. 98864. (3957.) D. 5148. Siran Island (N.), S. $80^{\circ}$ W., 3.8 miles (lat. $5^{\circ} 35^{\prime} 40^{\prime \prime}$ N., long. $120^{\circ} 47^{\prime} 30^{\prime \prime}$ E.), Sulu Archipelago. In 17 fathoms. February 16, 1908. Length $142 \mathrm{~mm}$.

Remarks.-In this species the postocular pit is well developed, the armature of the head strong, the suborbital stay with strong spines, 3 preopercular spines with the upper long, the scales large and the coloration variegated. It differs from Cymbacephalus nematophthalmus in the absence of the supraorbital tentacle.

(armatus, armed.)

\section{Family BEMBROPSIDAE}

Body long, slender in profile, deepest at front of first dorsal. Tail long, tapering gradually. Head long, broader than deep. Snout long, spatulate. Eye large, conspicuous, mostly before middle in head length. Mouth large, broad, lower jaw protruding. Maxillary small, extends below eye. Gill opening very large, extends forward before eye. Armature of head feeble, with inconspicuous small, slender, sharp spines. Scales large, thin, deciduous, smooth or searcely rough to touch. Head, excepting muzzle, scaly. Lateral line distinct. Two separate dorsal fins, anterior small, with slender, pungent spines. Anal opposite to and similar to second dorsal. Pectoral long, low. Ventral jugular, inserted close behind preopercle.

One genus. I have admitted this family on its divergence from the other trachinoid families. Its association with the Trachinidae by Alcock in 1899 and later by Jordan, Tanaka, and Snyder in 1913 in the Pteropsaridae is unnatural.

\section{Genus BEMBROPS Steindachner}

Body elongated, broad forward and tail becoming compressed posteriorly. Head large, depressed. Snout broad, concave in profile. Eyes very close together, separated only by narrow bony ridge of 
interorbital. Mouth wide, nearly horizontal. Teeth in villiform bands in jaws, on vomer and palatines. Tongue large, spatulate. Opercle with 3 spines. Angle of preopercle with feeble spines. Gill membranes free from isthmus. Gills 4. Pseudobranchiae large. Pyloric caeca 3. Scales cycloid or feebly ctenoid. Lateral line complete, its anterior scales keeled or feebly spinate. Small spine on shoulder girdle. First dorsal short, well separated from second.

\section{BEMBROPS FILIFER, new species}

\section{Figure 42}

Depth $81 / 2$; head $22 / 5$, width $22 / 3$. Snout $31 / 4$ in head from snout tip; eye $37 / 8,1 \frac{1}{8}$ in snout; maxillary reaches $1 / 5$ in eye, ends in pointed fieshy flap behind $1 / 3$ of eye, expansion $31 / 4$ in eye, length of bone $27 / 8$ in head from snout tip; villiform bands of teeth in jaws much broader above, 2 vomerine clusters rounded and well separated, and each palatine band long and narrow; nostrils small, well separated, with middle of interval separating them middle of snout length. Gill rakers $6+15$, lanceolate, equal gill filaments or $1 / 3$ of eye; 3 or 4 of upper and lower gill rakers short rudimentary tubercles. Preopercle with short spine at angle and another similar close above. Of 3 opercular spines uppermost curved upward and lowermost curved down, also most in advance. Small suprascapular spine slightly before uppermost opercular. Opercular flap long, pointed, extends back over front of pectoral.

Scales $50+2$ in lateral line, which well decurved over front of anal, ascends posteriorly, though slightly below middle along side of caudal peduncle to caudal base; 3 above at front of spinous dorsal, 6 above at front of soft dorsal, 5 below to front of anal. Scales on breast, belly and under surfaces small. Caudal with nearly basal half scaly. Pectoral base finely scaly. Maxillary scaly. Cheek with 5 or 6 rows of scales, of which uppermost and lowermost much smallest. Lateral line with large, simple tubes, all well exposed. Scales with 27 or 28 basal radiating striae; row of 23 to 25 subequal, short apical denticles; circuli fine, terminate apically at scale edge.

D. VI-I, 13, I, first spine ending in short filament not quite reaching soft dorsal origin, its length $22 / 5$ in total head length; A. 16, I, first ray $61 / 4$, fifteenth ray 5 ; caudal $2 \frac{1}{4}$, convex behind; least depth of caudal peduncle $62 / 5$; pectoral $12 \% 3$, rays II, 27 ; ventral rays I, 5 , fin $22 / 5$ in total head length.

Brown, little paler below. On back and upper surfaces edges of each scale pocket blackish brown, showing through overlapping scale as dark reticulation. Along side of body, below lateral line row of 8 to 10 obscure rather large brown blotches. Iris grayish. Dorsals and anals with dark or blackish brown membranes, fin rays all more 
or less paler. Caudal pale or light brown, edges all dark or blackish brown. Paired fins pale brown.

Type-U.S.N.M. no. 98866. D. 5216. Anima Sola Island, N. $44^{\circ}$ W., 29.50 miles (lat. $12^{\circ} 52^{\prime}$ N., long. $123^{\circ} 23^{\prime} 30^{\prime \prime}$ E.), between Burias and Luzon. In 215 fathoms. April 22, 1908. Length $260 \mathrm{~mm}$.

Also series of 74 other examples here considered as paratypes, from various stations in Philippine Seas, in 9 to 308 fathoms. Length 66 to $249 \mathrm{~mm}$.

Remarks.-Apparently related closely to Bembrops caudimacula Steindachner, but differing in the long first dorsal spine ending in a filament, thus much longest of all the dorsal spines. Compared with Alcock's figure minor points are the larger eye of $B$. filifer, more posterior insertion of the spinous dorsal, longer pectoral, and notched edge of the anal fin.

(filifer, thread bearer, with reference to the first dorsal spine.)

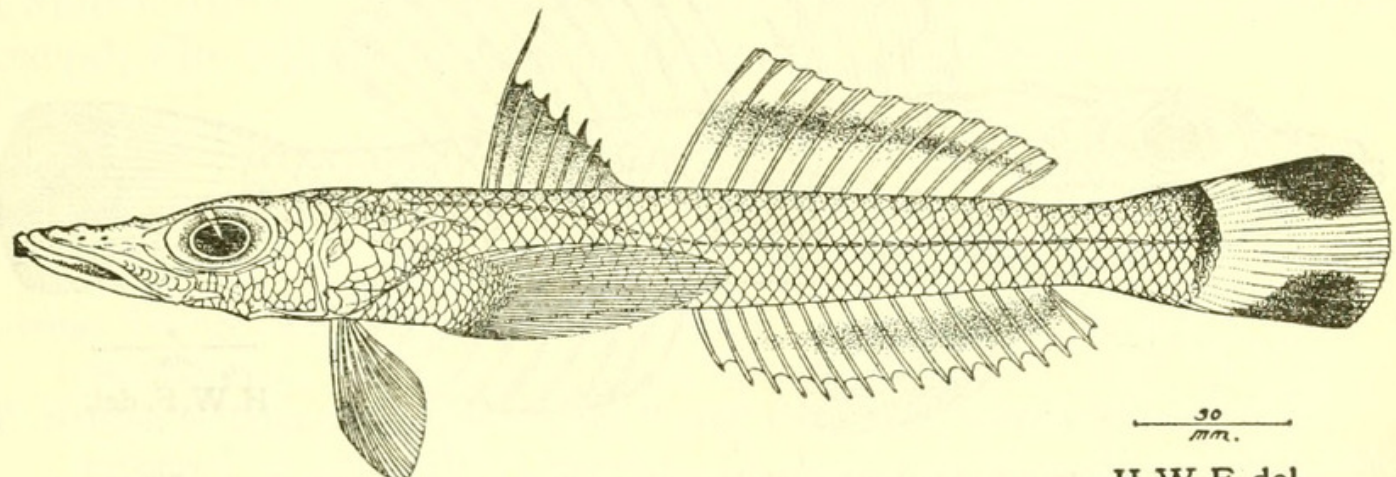

H.W.F. del.

FIGURE 42.-Bembrops filifer, new species. Type.

Family BEMBRIDAE

PARABEmbrinae, new subfamily

Type genus, Parabembras Bleeker.

Lateral line high, runs along upper side of back. Spinous dorsal larger than second dorsal, which with only 9 rays. Anal like second dorsal.

Includes only Parabembras.

\section{BEMBRINAE, new subfamily}

Type genus, Bembras Cuvier.

Lateral lines slope from suprascapula, median or axial along side of tail. Base of spinous dorsal always shorter than second dorsal base. Anal long, like second dorsal.

Includes Brachybembras, Bembradium, Bembradon, and Bembras. 


\section{BRACHYBEMBRAS, new genus}

Type.-Brachybembras aschemeieri, new species.

Related to Bembras, but differing in its shorter snout, shorter than eye, longer maxillary, and larger scales. Pair of internasal spines. Ventrals close set.

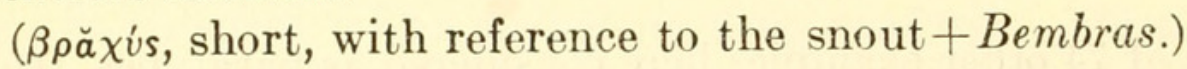

BRACHYBEMBRAS ASCHEMEIERI, new species

Figure 43

Depth $53 / 4$; head $2 \frac{1}{4}$, width $22 / 5$. Snout $32 / 5$ in head; eye 3 , little greater than snout, greatly exceeds very narrow interorbital; maxillary reaches $2 / 5$ in eye, expansion 2 in eye, length $2 \frac{1}{4}$ in head; teeth minutely villiform, in rather broad bands in jaws, narrower

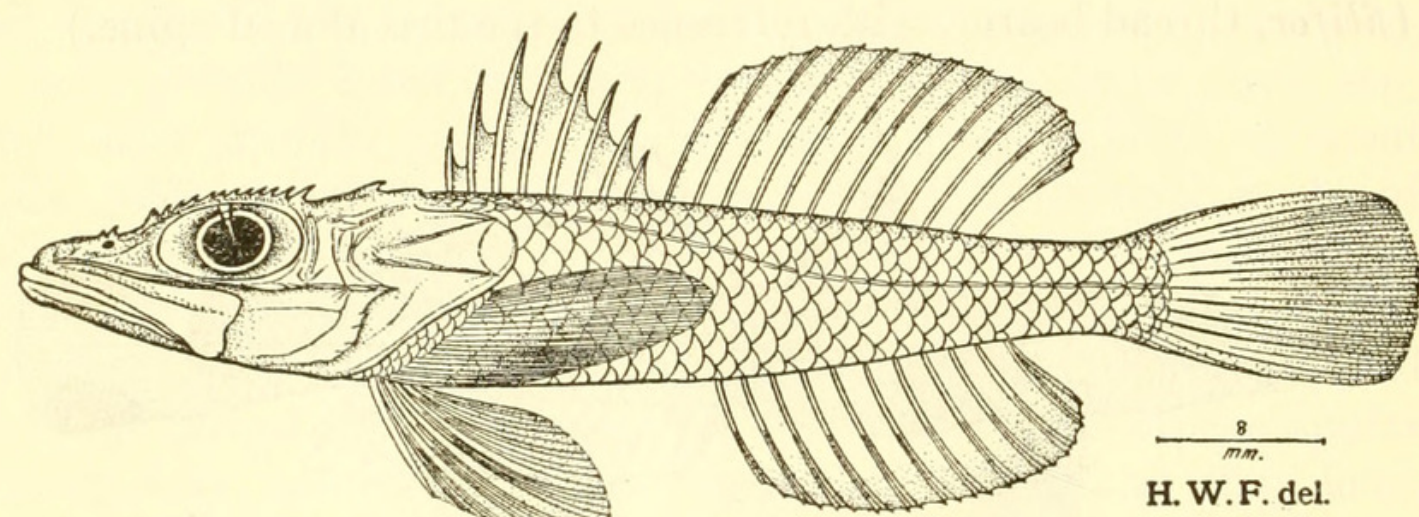

Figure 43.-Brachybembras aschemeieri, new genus, new species. Type.

band over vomer and down each palatine; interorbital width 6 in eye, deeply concave. Gill rakers $5+8$, though 5 above and below rudiments; gill rakers subequal with gill filaments which 5 in eye.

Two series of spines, with 2 spines in front one and 4 in hind one, between front nostrils; 11 supraorbital spines with first only very slightly enlarged and last followed by another slightly larger parietal spine; 2 more wide set and larger occipital spines; posterior orbital edge finely serrulate, medially with 2 postocular spines; pair of very small, close set backward directed serrae at front ridge of preorbital; keel of suborbital stay entire below first half of eye, then with 5 spines; preopercular spine short, bears large anterobasal spine, and below preopercular edge with 4 small spines, upper of which directed upward; 2 opercular spines, lower little in advance; suprascapular spine strong; short humeral spine.

Scales (pockets) $30+2$ in lateral line; 3 above, 6 below; 5 predorsal forward to occiput; 3 below suborbital stay on cheek. Head scaly behind and below eyes. Scales smaller on breast and belly than on 
sides of body. Small seales on caudal and pectoral bases. Lateral line rather high at first, with 4 or 5 scales each bearing a firm bony keel ending in small spine behind; course slopes gradually down until median along side of caudal peduncle. Scales with 9 basal radiating striae; 23 to 25 short uniserial apical denticles; circuli rather fine, coarse apically, where ending abruptly.

D. VIII-12, I, fourth spine $2 \frac{1}{2}$ in head, third ray $2 \frac{2}{5} ;$ A. $11, \mathrm{I}$, fifth ray $3 \frac{1}{8}$; caudal $13 / 4$, subtruncate, or slightly convex behind; least depth of caudal peduncle $6 \frac{1}{4}$; pectoral $2 \frac{1}{4}$, rays 21 ; ventral rays I, 5 , fin 2 in head.

Body pale brown. Head pale, nearly whitish on snout. Iris gray, with silvery white tinge. Fins all more or less grayish, many rays with more less whitish.

Type.-U.S.N.M. no. 98881. (9652.) D. 5172. Jolo Light, E. 24.75 miles (lat. $6^{\circ} 3^{\prime} 15^{\prime \prime}$ N., long. $120^{\circ} 35^{\prime} 30^{\prime \prime}$ E.), vicinity of Jolo. In 318 fathoms. March 5, 1908. Length $67 \mathrm{~mm}$.

(Named for C. R. Aschemeier, taxidermist of the U. S. National Museum, who has secured many fishes for the collections.)

\section{Family OPLICHTHYIDAE}

\section{ANALYSIS OF GENERA}

$a^{1}$. Areas before and below eyes moderate, so preorbital extent equals eye.

$b^{1}$. Scutes of lateral line each with 2 well developed spines which subequal or upper little larger

Oplichthys

$b^{2}$. Scutes of lateral line each with large single strong spine, directed up and back, so only single row of spines formed along each side of back; sometimes auxiliary small spine in interspaces between scutes and in line with larger spines_- Nionhoplichthys

$b^{3}$. Scales of lateral line each with large, erect, strong spine, besides an inner smaller superior spine, these forming 2 series of lateral spines, of which upper smaller and less conspicuous__-__-_-- Pristhoplichthys

$a^{2}$. Areas before and below eyes large, smooth and elongate, 1 to

$11 / 4$ times eye diameter Rhinhoplichthys

\section{MONHOPLICHTHYS, new genus}

Type.-Monhoplichthys gregoryi, new species.

Scutes of lateral line each with large single strong spine, directed up and back, so only single row of spines formed along each side of back. Sometimes auxiliary small spine in interspaces between scutes and in line with larger spines.

( $\mu$ óvos, one + Hoplichthys; with reference to the armature.) 
Depth $114 / 5$ to $123 / 4$; head $31 / 8$ to $31 / 5$, width $1 \frac{1}{3}$ to $1 \frac{1}{2}$. Snout $3 \frac{1}{10}$ to $31 / 2$ in head; eye $37 / 8$ to $4,1 \frac{1}{8}$ to $1 \frac{1}{6}$ in snout; maxillary extends below first $1 / 8$ in eye, length $21 / 8$ to $21 / 2$ in head; teeth minutely villiform, in bands in jaws, continuous band across vomer and band on each palatine; interorbital very narrow, width 6 in eye, deeply concave. Gill rakers $2+12$, rather short, firm, lanceolate, equal gill filaments or $1 / 5$ or eye.

Bones of head all finely or minutely serrate or striate, and on top of head pair of rather wide set spines represent parietal at upper hind orbital edge and strong short occipital pair, though both pairs small. Serrae of lateral ridge or suborbital stay all small, rather numerous, and 4 enlarged spines moderate, with first directed for-

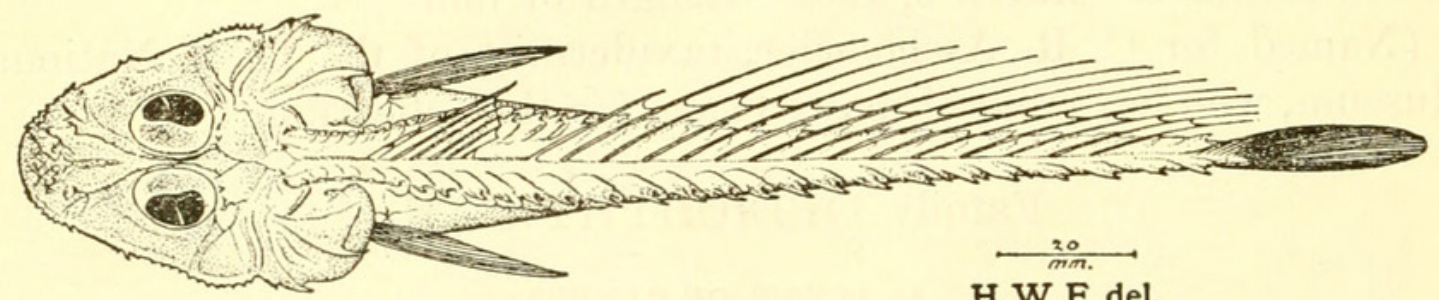

Figure 44.-Monhoplichthys gregoryi, new genus, new species. Type.

ward. Preopercular spine with anterior outer ridge bearing 8 or 9 graduated serrae up to large anterobasal spine; preopercular spine $1 \frac{1}{10}$ to $1 \frac{1}{4}$ in eye. Opercular spines rather slender, ends opposite. Strong keeled humeral spine. Lateral line with 28 to 29 spines, larger and stronger posteriorly.

D. VI-15, I, first spine $2 \frac{1}{8}$ to 3 in head, first ray $21 / 5$ to $31 / 8$ and sixth to eighth prolonged or filiform, or nearly long as head; A. 17, I, seventh ray $3 \frac{1}{2}$ to $33 / 4$, edge of membrane notched after tip of each; caudal $1 \frac{1}{2}$ to 2 , median rays longest, lower rays slightly longer, and hind edge of fin little oblique; least depth of caudal peduncle $33 / 4$ to $33 / 5$ in eye; pectoral reaches third anal ray or $1 \frac{9}{10}$ to 2 in head, rays 12 , III, or 13 , III, lowest ones detached, free, and $11 / 8$ to $11 / 5$ in fin; ventral rays I, 4 , fin $23 / 5$ to $23 / 4$ in head.

Pale or light brown, apparently largely whitish below. Iris light gray. Fins uniformly pale, nearly white. Spinous dorsal with membranes dark brown.

Type.-U.S.N.M. no. 98862. D. 5519. Point Tagolo Light, S. $71^{\circ}$ W., 8.7 miles (lat. $8^{\circ} 47^{\prime}$ N., long. $123^{\circ} 31^{\prime} 15^{\prime \prime}$ E.), vicinity of northern Mindanao. In 182 fathoms. August 9, 1909. Length 202 $\mathrm{mm}$. 
Remarks.-Besides the above are 6 paratypes, same data, 86 to 210 mm long. Apparently most closely related to Hoplichthys acanthopleurus Regan from Saya de Malha Ban, Indian Ocean. That species would differ in its lower spinous dorsal, "scarcely higher in the male than in the female", and shown in the original figure of the male as $31 / 4$ for first spine in the head, in the male most all the dorsal rays ending in long filaments and the 3 detached pectoral filaments $13 / 4$ in the fin.

(Named for Dr. William K. Gregory, of the American Museum of Natural History.)

MONHOPLICHTHYS PROSEMION, new species

Figure 45

Depth $121 / 2$; head $31 / 3$, width $11 / 4$. Snout $31 / 3$ in head; eye $32 / 3,11 / 8$. in snout; maxillary reaches first $1 / 8$ in eye, length $24 / 5$ in head; teeth minutely villiform, in bands in jaws, band over vomer and narrow:

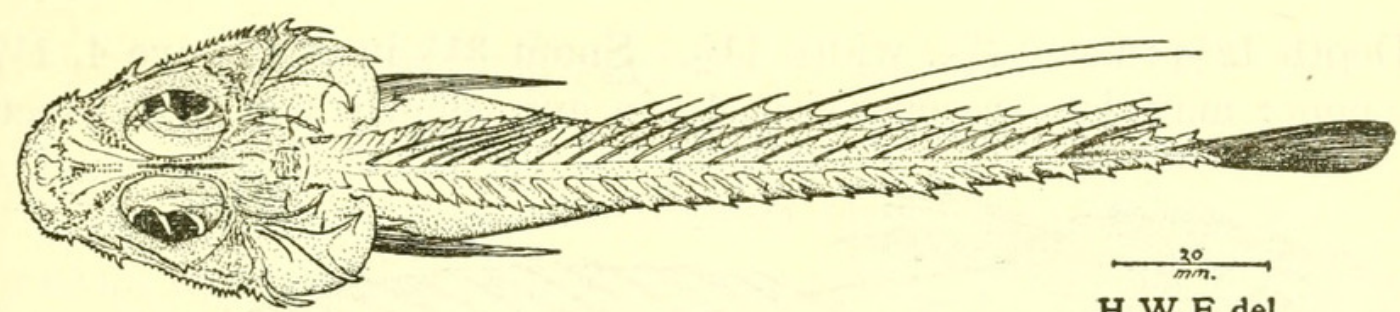

H. W.F. del.

Figure 45.-Monhoplichthys prosemion, new genus, new species. Type.

one on each palatine; interorbital narrow, concave, width 6 in eye. Gill rakers $2+12$, low, short, robust, $3 / 4$ of gill filaments, which 5 in eye.

Bones of head all finely or minutely serrate or striate, and on top of head pair of rather wide set spines represent parietal at upper hind orbital edge, and moderately large, strong, occipital pair, erect and directed back. Serrae of lateral ridge or suborbital stay well developed rather long, prominent, anterior flare forward, and only 2 others anteriorly little enlarged. Preopercular spine with anterior outer ridge bearing 5 spines, graduated to large antero-basal spine, which well curved upward; preopercular spine equals eye. Opercular spines well curved, upper little in advance. Strong, keeled, erect humeral spine. Lateral line with $28+1$ spines, larger and stronger posteriorly.

D. VI-15, I, end of spinous fin reaching base of second dorsal ray, first spine 2 in head, fifth to eighth rays greatly prolonged in filaments $11 / 4$ times head; A. 17 , I, seventh ray $32 / 3$ in head, edge of membrane notched after tip of each; caudal 17/8, slightly convex be- 
hind; least depth of caudal peduncle $31 / 3$ in eye; pectoral $17 / 8$ in head, rays 13 , III, lowest ones detached and slightly longer than fin; ventral rays $I, 4$, fin $2 \frac{1}{8} 8$ in head.

Back and head above brown, latter paler marginally. Iris gray. Under surfaces whitish. Fins pale, pectoral and caudal terminally with brownish. Ventrals and anal whitish.

Type.-U.S.N.M. no. 98863 . D. 5117. Sombrero Island, S. $17^{\circ}$ E., 10.80 miles (lat. $13^{\circ} 52^{\prime} 22^{\prime \prime}$ N., long. $120^{\circ} 46^{\prime} 22^{\prime \prime}$ E.), Balayan Bay and Verde Island Passage. In 118 fathoms. January 21, 1908. Length $173 \mathrm{~mm}$.

Remarles.-Differs from Monhoplichitys gregoryi in the long spinous dorsal, larger eyes, more conspicuous armature of the head, and filiform dorsal rays.

( $\pi \rho$ ó, forward $+\sigma \eta \mu . \epsilon \hat{\imath} 0 v$, banner; with reference to the dorsal fin.)

MONHOPLICHTHYS SMITHI, new species

Figure 46

Depth $121 / 4$; head $32 / 5$, width $1 \frac{1}{2}$. Snout $31 / 2$ in head; eye $4,1 \frac{1}{10}$ in snout; maxillary reaches first $1 / 8$ in eye, length 3 in head; teeth

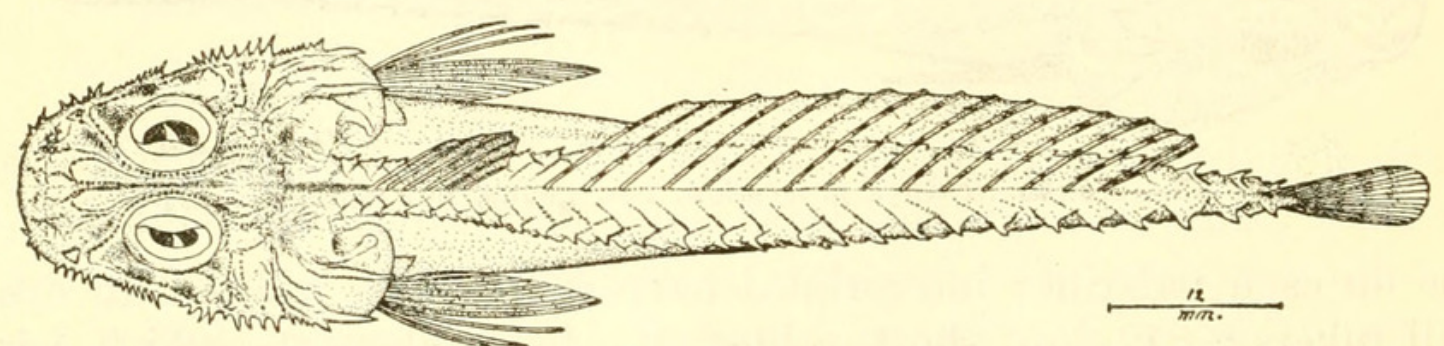

H. W.F. del.

Figure 46.-Monhoplichthys smithi, new genus, new species. Type.

minutely villiform, in narrow bands in jaws, band narrowly over vomer and similar one on palatine; interorbital narrow, concave, width 4 in eye. Gill rakers $2+9$, short, robust points, little less than gill filaments, which 5 in eye.

Bones of head moderately rugose striate or minutely serrate, and on top of head pair of moderately spaced small parietal spines, and posteriorly pair of occipital spines equidistant. Spines of lateral ridge or suborbital stay all rather large, well developed, anterior flare forward, likewise some below eye. Preopercular spine with anterior outer ridge bearing 4 spines, graduated to large anterobasal spine, which only slightly slopes upward; preopercular spine equals eye. Opercular spines curved, ends opposite. Strong, keeled, erect humeral spine. Lateral line with 28 spines, larger and stronger posteriorly. 
D. VI-15, I, end of depressed spinous fin reaches $3 / 4$ to origin of soft dorsal, first spine $3 \frac{1}{4}$ in head, third ray $2 \frac{1}{3} ; \mathbf{A}$. 17 , I, seventh ray $23 \%$; least depth of caudal peduncle 3 in eye; caudal 2 in head, apparently convex behind; pectoral $1 \frac{1}{2}$ in head, rays 12 , III, lowest ones detached and 11/5 times fin; ventral rays $I, 4$, fin 2 in head.

Brown above, pale to whitish below. Eye gray. First dorsal dark brown. Second dorsal with several brownish spots on each ray. Caudal with 4 or 5 indistinct dark transverse bars. Pectoral brownish, with obscure small dark variable spots, lower 3 rays whitish. Ventrals and anal whitish.

Type-U.S.N.M. no. 59588. Kagoshima, Japan. Dr. H. M. Smith. 1903. Length $99 \mathrm{~mm}$.

Remarks.-Differs from Monhoplichthys gilberti (Jordan and Richardson), also from Japan, in the longer maxillary reaching below the front of the eye, conspicuous armature of the head, and long detached pectoral rays.

(Named for Dr. Hugh M. Smith.)

\section{PRISTHOPLICHTHYS, new genus}

\section{Type--Hoplichthys platophrys Gilbert.}

Scutes of lateral line each bearing large, erect, strong spine, besides an inner smaller superior spine, thus forming 2 series of lateral spines of which the upper is smaller and less conspicuous. Interorbital broad as eye. Armature of head moderate.

One species: Pristhoplichthys platophrys, of Hawaiian seas.

( $\pi$ pi $i \tau \eta \eta s$, one who saws + Hoplichthys, with reference to the armature.)

\section{PRISTHOPLICHTHYS PLATOPHRYS (Gilbert)}

Hoplichthys platophrys GILBERT, Bull. U. S. Fish Comm., vol. 23, pt. 1, p. 642, fig. 250, 1903 (1905) (type locality, Laysan Island, in 351 fathoms).Fowler, Mem. Bishop Mus., vol. 10, p. 300, 1928 (copied).

Depth 10 ; head $23 / 4$, width $1 \frac{1}{5}$. Snout 3 in head; eye $4 \frac{1}{3}, 1 \frac{1}{2}$ in snout, little greater than interorbital; maxillary reaches opposite front eye edge; teeth very minute, villiform, in narrow bands in jaws, on vomer and palatines; interorbital width 5 , concave. Gill rakers $2+7$ ?, short, less than gill filaments, which 3 in eye.

Bones of head with minute denticles or serrae, and on top of head pair of moderately wide set parietals, with a postocular spine on each suprapostocular ridge, and pair of moderately close set occipitals. Serrae of lateral ridge or suborbital stay all moderate, distinct, 3 anterior each side directed forward and inward and one each side opposite hind nostrils slightly larger and directed outward. Preopercular outer ridge bears 3 or 4 spines graduated to larger antero- 
basal spine, which flares out and back; preopercular spine 345 in head. Opercular spines little curved, lower slightly shorter or in advance. Strong sharp humeral spine. Lateral line with 27 spines, all erect and larger and stronger posteriorly.

D. VI-15, I, first spine long as eye, first ray 4 in head, fifth ray $2 \frac{2}{3}$; A. 18 , I, fin height $32 / 3$; caudal $2 \frac{1}{2}$, little convex behind; least depth of caudal peduncle 2 in eye; pectoral $11 / 3$ in head, rays $13, \mathrm{II}$, lower detached rays with basal webs so about half adnate, length half of fin; ventral rays $I, 5$, fin $21 / 3$ in head.

Brown, paler below. Above 4 brownish transverse blotches, now 3 most distinct on flanks and tail. Iris gray. Spinous dorsal blackish terminally. Each ray of soft dorsal with several dark spots. Anal whitish, tinted with brownish on rays. Caudal whitish, little dark basally, gray terminally. Pectoral with some brownish, other fins whitish.

Type.-U.S.N.M. no. 51620. (3952.) Near Laysan Island. In 347 to 351 fathoms. May 21, 1902. Length $70 \mathrm{~mm}$.

Known only from the type, described above.

\section{RHINHOPLICHTHYS, new genus}

Type.-Hoplichthys haswelli McCulloch.

Distinguished from Oplichthys by the very large smooth and elongated areas before and below the eyes, so the preorbital extent of this area at least 1 to $1 \frac{1}{4}$ times the eye diameter. Snout elongated and spatulate. Interorbital moderate. Vomer with a large patch of enlarged, simple, pointed teeth, giving off two long, pointed extensions behind.

('piv, snout +Hoplichthys.)

\section{Family TRIGLIDAE}

\section{ANALYSIS OF GENERA}

$\boldsymbol{a}^{\mathbf{1}}$. Triglinae. Row of spine bearing bony bucklers along bases of both dorsal fins. (Type genus, Trigla Linnaeus.)

$\boldsymbol{b}^{1}$. Scales larger, 50 to 60 in lateral line.

$c^{1}$. Lateral line armed with spiny plates

Paratrigla

$c^{2}$. Lateral line unarmed.

$d^{1}$. Erect spiny bucklers along bases of both dorsals

Lepidotrigla

$d^{2}$. Flattened spiny bucklers along spinous dorsal base, erect along soft dorsal base

Pachytrigla

$\boldsymbol{b}^{2}$. Scales smaller, 100 or more in lateral line.

$e^{1}$. Head usually with small spines; scapular spine moderate 
$a^{2}$. Pterygotriglinae. Large bucklers only along spinous dorsal base or absent. (Type genus, Pterygotrigla Waite.)

$f^{1}$. Few bony bucklers only along spinous dorsal base.

$g^{1}$. Upper opercular spine short, reaches pectoral origin; humeral spine elongate.

$h^{1}$. Scapular spine very short; rostral spines short; no postero-supraorbital spine

Pterygotrigla

$h^{2}$. Scapular spine long and strong; rostral spines long.

$i^{1}$. Snout shorter, length 2 or more in head.

$j^{1}$. Maxillary reaches $\%$ to eye; rostral spines long as eye

Bovitrigla

$j^{2}$. Maxillary reaches eye; rostral spine $2 / 3$ rest of head

Dixiphistops

$i^{2}$. Snout long, $13 \frac{1}{4}$ in head; maxillary not reaching eye; rostral spine $2 / 3$ rest of head

Dixiphistes

$g^{2}$. Upper opercular spine enlarged, long, reaches $1 / 3$ in pectoral; humeral spine short Otohime

$f^{2}$. No bony plates or bucklers along dorsal base Dixiphichthys

\section{Genus LEPIDOTRIGLA Günther}

\section{Subgenus LePidotrigla Günther}

Each bony buckler, along each side of the bases of the dorsal fins, with a large, simple, entire spine.

Of the typical species Lepidotrigla cavillone (Lacépède) I have examined two specimens: U.S.N.M. no. 2219, Europe; C. L. Bonaparte Collection, Acad. Nat. Sci. Philadelphia. Length 85 to $110 \mathrm{~mm}$, caudal fins broken.

\section{LEPIDOTRIGLA OGLINA, new species}

\section{Figure 47}

Depth $3 \frac{1}{2}$ in body from snout tip; head 3 , width $1 \frac{1}{2}$. Snout $21 / 2$ in head; eye $3,1 \frac{1}{5}$ in snout, greater than interorbital; preorbital depth below front eye edge $13 / 7$ in eye; maxillary reaches $1 / 5$ in eye, length $24 / 5$ in head; teeth minutely villiform, in rather broad bands in jaws, none on palate; interorbital 4, deeply concave. Gill rakers $0+10$, short, $4 \frac{1}{2}$ in eye, subequal with gill filaments.

Pair of short, broad, rostral spines, edge of each inside with several denticles; supraorbital ridge finely serrated, with 2 low anterior denticles, and larger posterior strong spine, followed by short notch; suprascapular spine short, sharp pointed; postocular ridge serrated, ends in short spine; no keel to suborbital stay, and preopercle without spines; opercle with pointed spine, level with lower edge of eye; humeral spine long, slender, equals eye, base broad. 
Scales 52 in lateral line to caudal base, tubes small and simple; 3 scales above lateral line opposite soft dorsal origin, 13 below, 7 predorsal. Chest, breast, prepectoral, and region narrowly behind paired fins naked. Caudal largely covered with small scales, more numerous basally. Along dorsal bases 22 bony plates, each with strong spine, and 8 along first dorsal. Scales of lateral line not enlarged, though rather narrowly imbricated. Scales with 5 or 6 basal radiating striae; 18 to 20 short, broad apical spines; circuli fine, obsolete or end abruptly apically.

D. IX-14, first spine with front edge serrated, second spine $13 / 5$ in head, third ray $27 / 8$; A. 15 , I, fourth ray $3 \frac{1}{2}$; caudal $1 \frac{1}{2}$, little concave behind; least depth of caudal peduncle $21 / 4$ in eye; pectoral reaches $21 / 8$ to caudal base, uppermost of 3 lower detached rays $11 / 8$ in

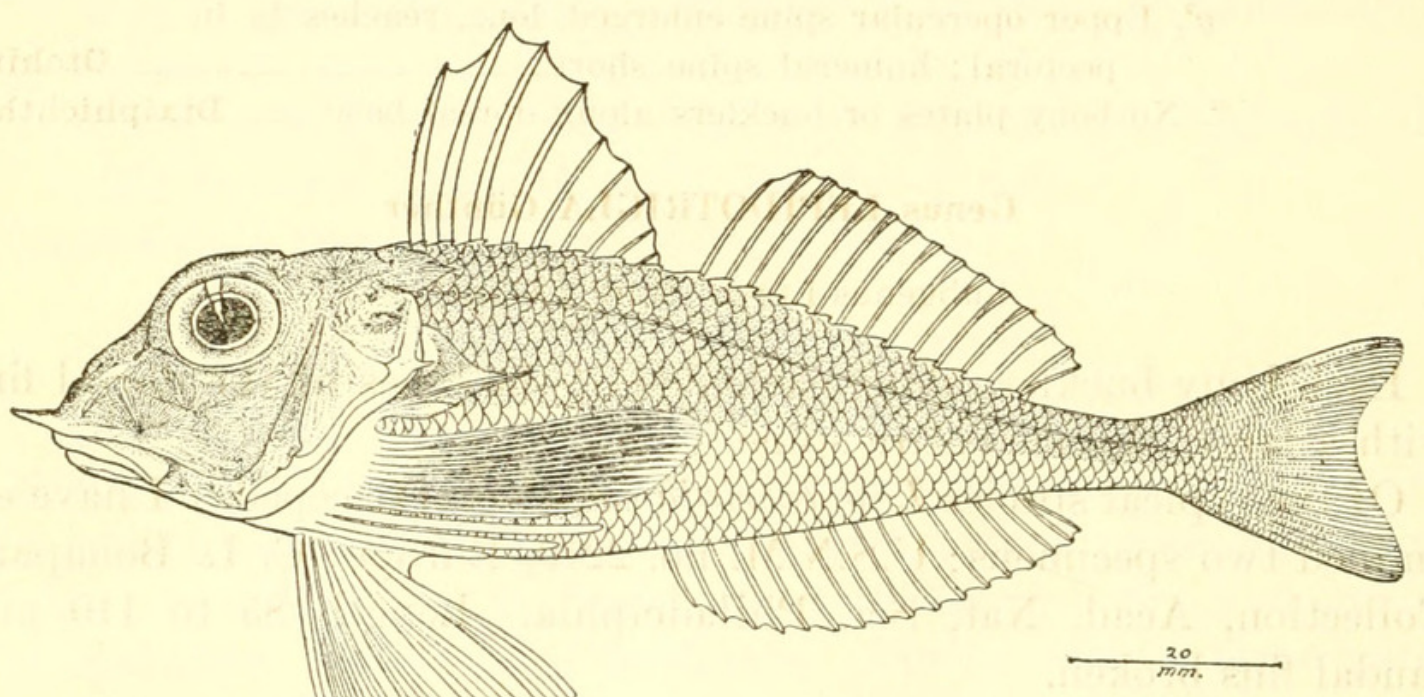

H. W. F. del.

Figure 47.-Lepidotrigla oglina, new species. Type.

upper section of fin, rays I, 7, III-III, upper section of fin reaches base of third anal ray, length $1 \frac{1}{8}$ in head; ventral $1 \frac{1}{8}$, rays $I$, 5 , fin reaches little beyond base of fourth anal ray.

Head pale brown. Iris pale, evidently white. Body with upper $3 / 5$ brown and remaining lower portion white, line of demarcation pronounced. Upper section of pectoral largely gray black, white all around, and outer face of each ray narrowly whitish. Fins otherwise pale or whitish. Under surface of body with more or less silvery white reflections.

Type.-U.S.N.M. no. 98865. (1349.) D. 5315. Lat. $21^{\circ} 40^{\prime}$ N., long. $116^{\circ} 58^{\prime}$ E., China Sea in vicinity of Formosa. In 148 fathoms. November 5, 1908. Length $129 \mathrm{~mm}$.

Only the type known. This differs from all other species in its very large eye, exceeding the depth of the preorbital.

(ogle, with reference to the large eyes.) 
Depth $4 \frac{1}{3}$ to $4 \frac{2}{3}$ measured from snout tip; head 3 to $3 \frac{1}{4}$, width $12 / 3$ to 2 . Snout $22 / 5$ to $21 / 2$ in head from snout tip; eye $31 / 3$ to $32 / 5$, $11 / 3$ to $12 / 5$ in snout, 2 to 3 times interorbital width; maxillary reaches below front edge of eye, length $2 \frac{1}{3}$ to $23 / 4$ in head from snout tip; mouth width $23 / 4$ to $31 / 8$; narrow bands of minute villiform teeth in jaws, none on palate; interorbital 7 to 9 , deeply concave. Gill rakers $0+7$, lanceolate, $1 \frac{1}{4}$ in gill filaments or 4 in eye.

Pair of short, triangular, broad, fiat, rostral spines, more or less flaring out, and edges entire; 2 antero-supraorbital spines each side and 2 postero-supraorbitals each side, close and with rather deep transverse groove close behind; ridge of suborbital stay obsolete or not developed and no spine at preopercle angle; strong, pointed

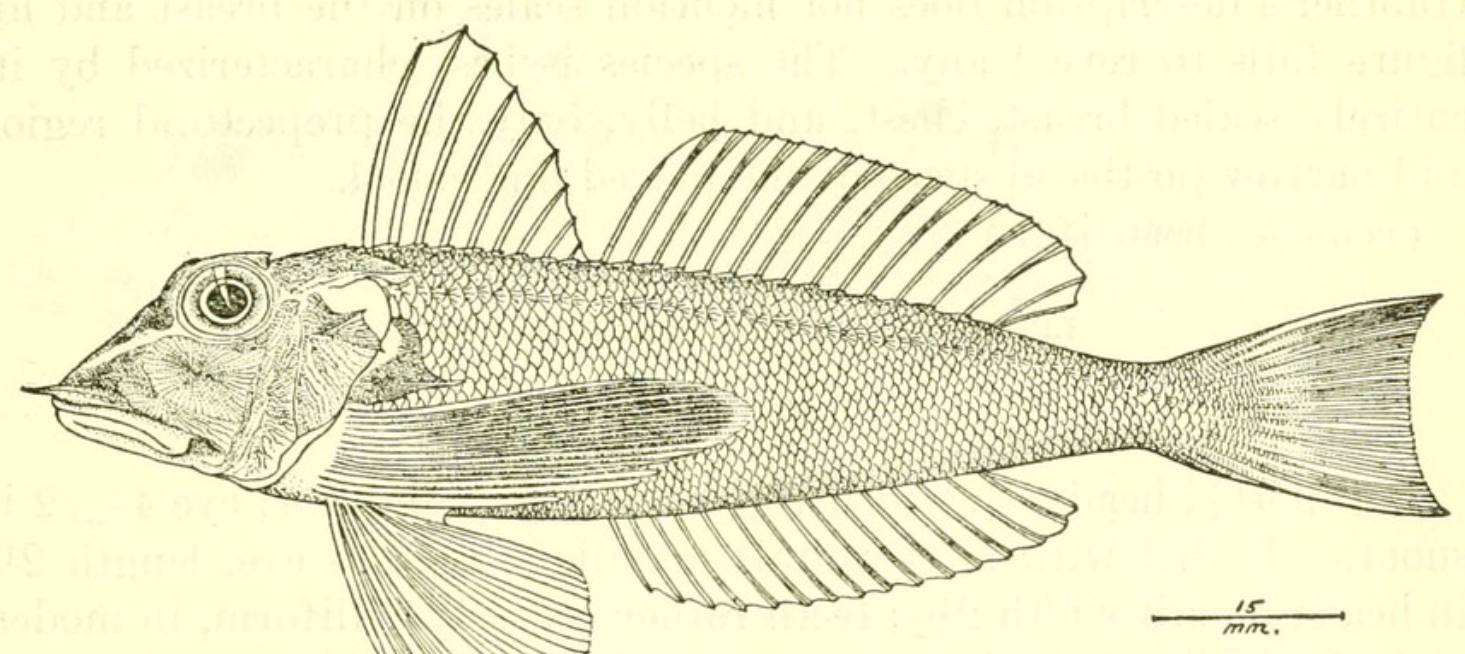

H.W. F. del.

Figure 48.-Lepidotrigla venusta, new species. Type.

suprascapular spine; small, pointed opercular spine, level with lower edge of eye; strong pointed humeral spine with broad, deep base, longer than spine.

Scales 52 to 54 in lateral line to caudal base and 2 or 3 more on

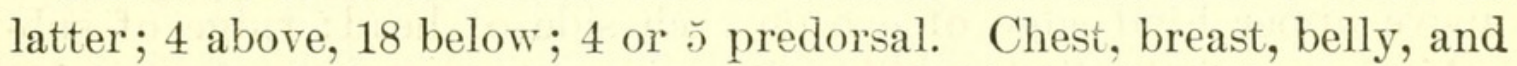
caudal base finely scaled, only small area behind paired fins and prepectoral region naked. Along each side of bases of dorsals 23 bucklers, each bearing a strong spine. Lateral line little high, distinct, each scale usually with trifid tubes. Scales with 5 to 13 basal radiating striae; 0 to 6 short apical points; circuli fine, concentric.

D. IX-15, I, first spine $13 / 7$ to $13 / 5$ in head, third ray 2 to $2 \frac{1}{8}$; A. 15 , I, third ray $22 / 5$ to 3 ; caudal $1 \frac{1}{3}$ to $1 \frac{1}{4}$, little emarginate behind; least depth of caudal peduncle $12 / 5$ to $1 \frac{1}{2}$ in eye; pectoral $21 / 2$ to $25 \%$ in length from snout tip to caudal base, reaches $13 / 4$ to 2 to caudal base, 
rays I, 6 , IV-III, uppermost ray of lower section $1 \frac{1}{8}$ to $11 / 5$ in upper section of fin; ventral reaches second anal ray, fin $11 / 8$ to $11 / 5$ in head, rays $I, 5$.

Head brownish, whitish on sides and below with silvery reflections. Upper half of body pale brownish, lower half of sides silvery white. Pectoral with upper section marked with a large uniform blackish brown blotch, leaving entire fin border white. Fins otherwise all pale to whitish.

Type.-U.S.N.M. no. 98872. (24328.) D. 5442. San Fernando Point Light, N. $39^{\circ}$ E., 8.4 miles (lat. $16^{\circ} 30^{\prime} 36^{\prime \prime}$ N., long. $120^{\circ} 11^{\prime} 06^{\prime \prime}$ E.), west coast of Luzon. In 45 fathoms. May 10, 1909. Length $111 \mathrm{~mm}$. Also a series of Philippine paratypes.

Remarks.-This species appears to be related to Lepidotrigla spiloptera Günther, though that species with a broader interorbital, shorter pectoral, truncate caudal, and ventrals only reaching anal. Günther's description does not mention scales on the breast and his figure fails to reveal any. The species is best characterized by its entirely scaled breast, chest, and belly, only the prepectoral region and narrow postbasal space of the paired fins naked.

(venusta, beautiful.)

\section{LEPIDOTRIGLA PECTORALIS, new species}

Figure 49

Depth $4 \frac{1}{4}$; head $23 / 4$, width $13 / 4$. Snout $2 \frac{1}{1} 10$ in head; eye $42 / 5,2$ in snout, subequal with interorbital; maxillary reaches eye, length $21 / 8$ in head; mouth width $2 \frac{1}{2}$; teeth rather coarsely villiform, in moderately broad bands in jaws, none on palate; interorbital $42 / 5$ in head, low, broadly depressed concavely. Gill rakers $0+8$, of which 3 lowest mere rudimentary tubercles; short, strong, lanceolate, $3 / 5$ of gill filaments, which $2 \frac{1}{4}$ in eye.

Head largely unarmed or few spines developed very short, small or inconspicuous; bones of head with distinct, radiating, rugose striate surfaces; preocular groove narrow, forward to nostrils; notch above upper hind edge of eye on each side of head; ridge of suborbital stay little distinct and without any armature, and no spine on preopercle; opercle ends in rather broad point behind; as viewed above upper front edge of head blunt with row of small marginal denticles; long strong humeral spine, 3 in head.

Scales $53+4$ in lateral line, enlarged and tubes simple; 6 above opposite soft dorsal origin, 20 below to anal origin; 10 predorsal. Small and minutely ctenoid scales on predorsal, trunk and tail and extended over caudal basally. Breast, chest, prepectoral, belly, and region from basal part of humeral spine to vent naked. Along dor- 
sal bases 27 spinous bucklers, of which 10 along spinous dorsal base. Scales with 8 to 10 rather large, parallel erect denticles on apical half; circuli fine, even.

D. IX-18, third spine $21 / 5$ in head, third ray $21 / 2 ;$ A. 17 , eighth ray 3 ; caudal $13 / 5$, slightly concave behind; least depth of caudal peduncle $13 / 5$ in eye; pectoral reaches $1 \frac{1}{4}$ to caudal, $14 / 5$ in fish without caudal; pectoral rays II, 5, IV-III, uppermost of 3 lower detached rays $21 / 8$ in upper section of pectoral; ventral $1 \frac{1}{4}$ in head, reaches front of anal.

Light brown, under surface of head and belly whitish. Iris pale to whitish. Spinous dorsal pale with gray black blotch broadly terminal on fourth to eighth membranes. Pectoral with upper half of upper section gray black. Fins otherwise all pale or whitish.

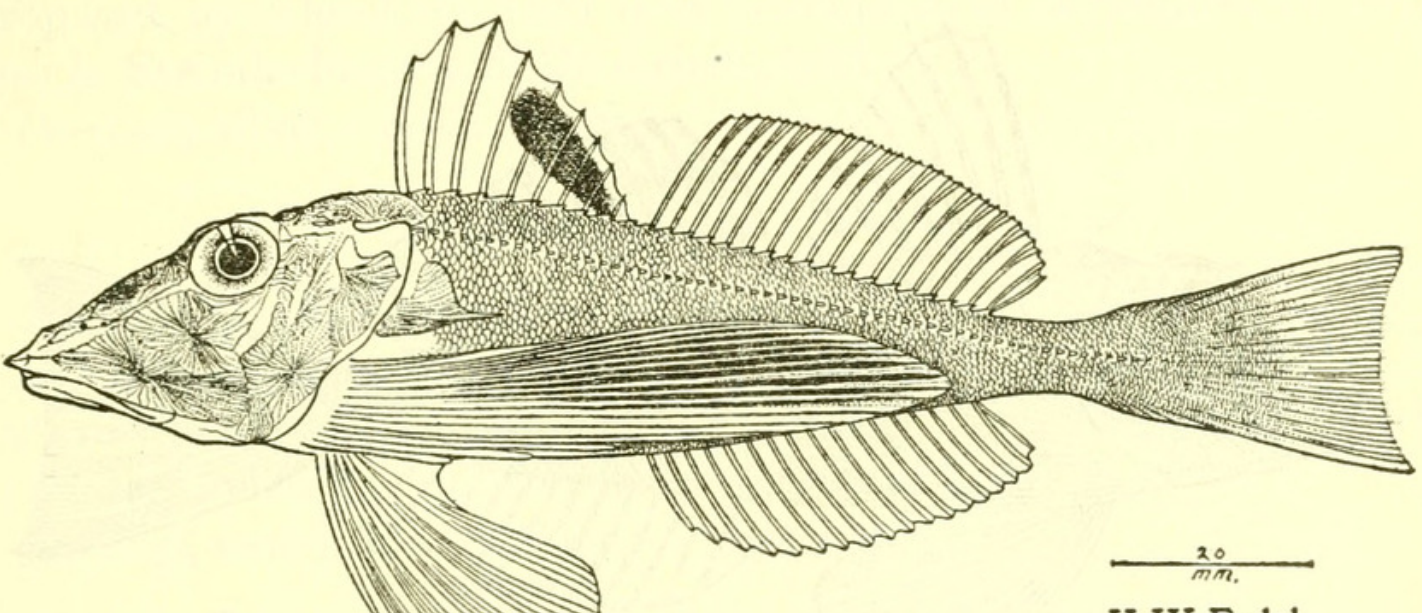

H.W.F. del.

Figure 49.-Lepidotrigla pectoralis, new species. Type.

Type.-U.S.N.M. no. 98878. (4256.) D. 5517. Point Tagolo Light, S. $83^{\circ}$ W., 10.5 miles (lat. $8^{\circ} 45^{\prime} 30^{\prime \prime}$ N., long. $123^{\circ} 33^{\prime} 45^{\prime \prime}$ E.), vicinity of northern Mindanao. In 169 fathoms. August 9, 1909. Length $140 \mathrm{~mm}$.

Remarks.-Suggestive of Lepidotrigla japonica (Bleeker) but that species with greatly larger scales, different physiognomy, much shorter scaly predorsal and larger suprascapular spine, also without the large black blotch on the spinous dorsal.

(pectoralis, pectoral, with reference to its long pectorals.)

\section{LEPIDOTRIGLA ARGYROSOMA, new species}

\section{Figure 50}

Depth $42 / 3$ (in length measured from snout tip); head $31 / 6$, width $14 / 5$. Snout $21 / 4$ in head; eye $31 / 2,11 / 2$ in snout, greatly exceeds interorbital; maxillary reaches opposite front eye edge, length $21 / 2$ in head; teeth minute, villiform, in narrow bands in jaws, none on pal- 
ate; interorbital 8 , deeply concave. Gill rakers $1+10$, of which 4 lowest mere short low rudiments; lanceolate, $21 / 2$ in eye, longer than gill filaments.

Pair of broad, flat, triangular, divergent, rostral spines, extended forward, half of eye; 2 antero-supraorbital spines each side and postero-supraorbital spines each side, close and with rather deep transverse groove close behind; ridge of suborbital stay obsolete, little developed, and with only very short, small spine at preopercle angle; strong, pointed, suprascapular spine; smaller, pointed opercular spine, level with lower edge of eye; strong pointed humeral spine, with broad deep base, subequal with length of spine.

Scales 53 or 54 in lateral line to caudal base and 2 or 3 more on latter; 4 above, 19 or 20 below; 5 predorsal. Chest, breast, belly,

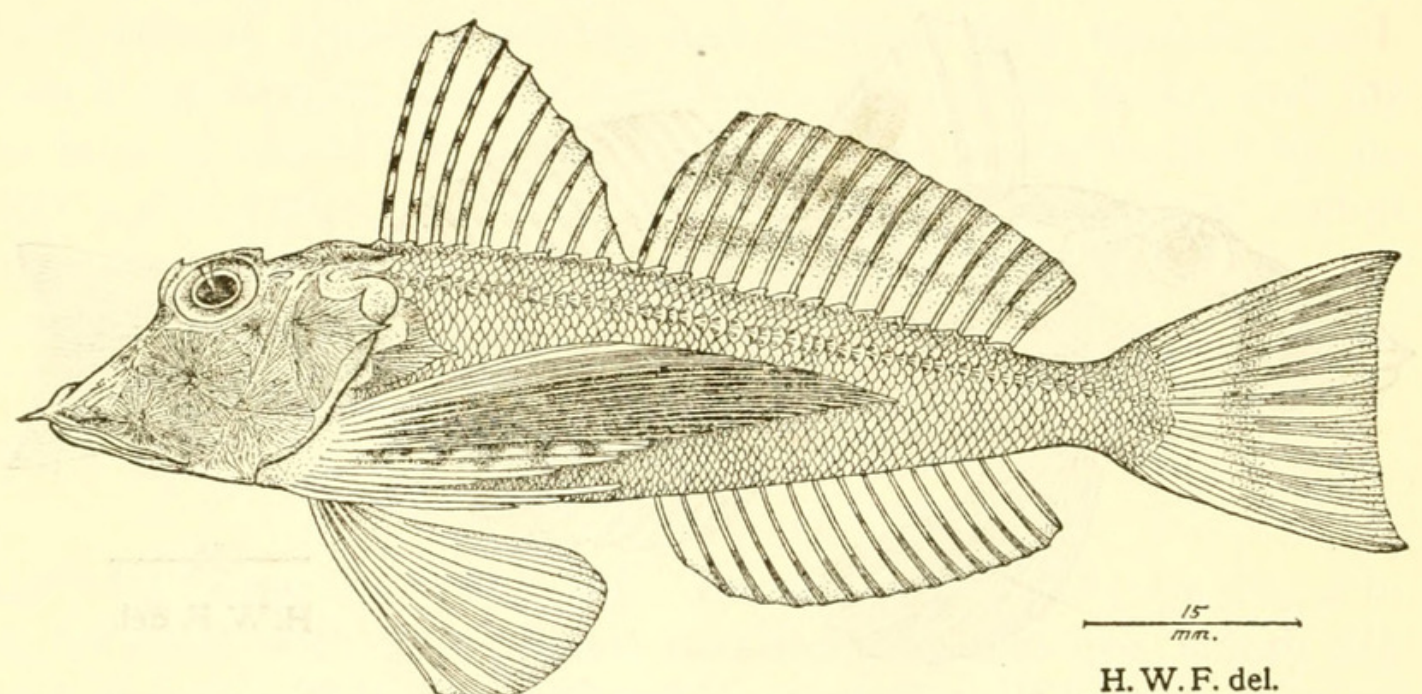

Figure 50.-Lepidotrigla argyrosoma, new species. Type.

and caudal base finely scaled, only prepectoral region and small area behind bases of paired fins naked. Along each side of bases of dorsals 23 bucklers each bearing a strong spine. Lateral line little high, distinct, each scale with trifid tubes. Scales with 4 to 6 basal radiating striae; 0 to 8 short strong apical points; circuli fine, concentric, often obsolete apically.

D. IX-15, first spine $1 \%$ in head, third ray $2 ;$ A. 15 , seventh ray $24 / 5$; caudal $1 \frac{1}{3}$, emarginate behind; least depth of caudal peduncle $1 \frac{1}{3}$ in eye; pectoral reaches $11 / 2$ to caudal base, $2 \frac{1}{8}$ in length from snout tip to caudal base, reaches eleventh anal ray base, rays I, 5, IV-III, uppermost ray of lower section $13 / 5$ in upper section of fin; ventral reaches fourth anal ray base, fin $1 \frac{1}{10}$ in head, rays $\mathrm{I}, 5$.

Head brownish, with silvery reflection and pale lilac tints on sides and below eye. Upper half of body pale fawn brown, lower half white with silvery tints. Dorsal spines each with 4 or 5 dull brown blotches. Second dorsal with 2 rows of brownish spots, 2 spots on 
each membrane. Upper section of pectoral with large gray black blotch, border all around whitish, also each ray on outer face narrowly whitish. Ventral pale yellowish brown, edge all around white. Fins otherwise whitish.

Type-U.S.N.M. no. 98873. (24363.) D. 5442. San Fernando Point Light, N. $39^{\circ}$ E., 8.4 miles (lat. $16^{\circ} 30^{\prime} 36^{\prime \prime}$ N., long. $120^{\circ} 11^{\prime} 06^{\prime \prime}$ E.), west coast of Luzon. In 45 fathoms. May 10, 1909. Length $94 \mathrm{~mm}$.

Also a series of Philippine paratypes.

Remarks.-Apparently this is close to, if not synonymous with, Lepidotrigla spiloptera var. longipinnis Alcock. According to Alcock it "only differs from the type in the great length of the pectoral fins, which reach to, or beyond, the 9 th anal ray." As this name was proposed by Alcock in 1890 it is precluded by Lepidotrigla longipinnis Steindachner and Döderlein, 1887.

(ä $\rho \gamma \check{v} \rho o s$, silver $+\sigma \tilde{\omega} \mu a$, body.)

\section{Pristhoplotrigla, new subgenus}

\section{Type.-Lepidotrigla strauchi Steindachner.}

Characterized by the spinous bucklers, in a row each side of the base of the first dorsal fin, with a serrated edge. This is also visible in a lateral view but not shown on published figures.

$(\pi \rho i \sigma \tau \eta s$, saw $+\ddot{o} \pi \lambda o \nu$, armor + Trigla. $)$

Stagonotrigia, new subgenus

Type-Lepidotrigla macrobrachium, new species.

This group is defined chiefly by the spotted dark area of the pectoral fins, as seen from the inside. The pectoral is variable in length, from short to long.

$(\sigma \tau a \gamma \dot{\omega} \nu$, spot + Trigla.)

LEPIDOTRIGLA PUNCTIPECTORALIS, new species

Figure 51

Depth $4 \frac{1}{2}$ in length measured from snout tip; head $3 \frac{1}{10}$, width $12 / 5$. Snout $21 / 6$ in head from snout tip; eye $37 / 8,14 / 5$ in snout, slightly greater than interorbital; maxillary reaches $7 / 8$ to eye, length 3 in head from snout tip; mouth width $2 \frac{1}{2}$; teeth minutely villiform, in bands in jaws, upper band broadly exposed when mouth closes; interorbital $5 \frac{1}{3}$ in head from snout tip, deeply concave. Gill rakers: $1+13$, of which lowest 6 mere rudiments; longest $3 / 4$ of gill filaments, which $2 \frac{1}{2}$ in eye.

Pair of broadly flattened, triangular rostral spines, about $2 \frac{1}{2}$ in eye, edges of each entire; 2 low, short, antero-supraorbital spines 
each side, followed by close set, low, broad pair above hind eye edge, behind which a deep notch; pair of low, small occipital spines; suprascapula with broad plate bearing strong spine with keel forward; strong horizontal postocular keel bearing several close set points behind; ridge of suborbital stay little developed, only below eye, ends in blunt spine at preopercle angle; small opercular spine, level with lower edge of eye, extends back little over gill opening; large, broad humeral plate with horizontal keel ending in strong, slender spine, slightly longer than eye.

Scales 58 in lateral line to caudal base, each with 5 or 6 divergent tubules; 4 above to soft dorsal origin, 16 below; 7 predorsal. Chest, breast, prepectoral region and basal region close behind paired fins naked. Small scales on belly and caudal base. Along bases of dorsals

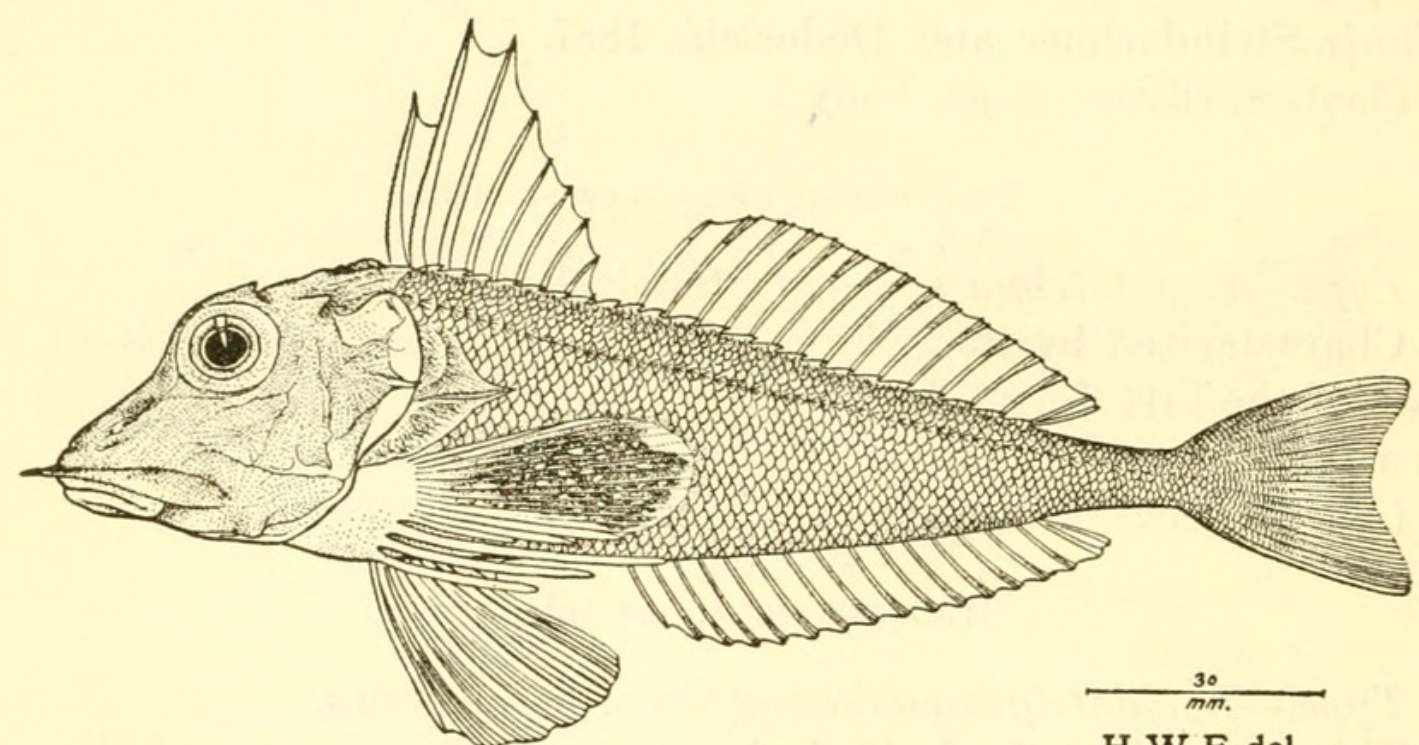

H.W.F. del.

Figdre 51.-Lepidotrigla punctipectoralis, new species. Type.

each side 23 bony bucklers, each armed with a strong spine, of which 8 along base of spinous fin. Scales with 4 to 6 basal radiating striae; row of 13 to 15 rather triangular apical denticles; circuli fine, obsolete apically.

D. $\mathrm{X}-15$, I, second spine $1 \frac{1}{2}$ in head from snout tip, fifth ray 3 ; A. 16 , fifth ray 4 ; caudal $1 \frac{1}{2}$, slightly emarginate behind; least depth of caudal peduncle $13 / 4$ in eye; pectoral $1 \frac{1}{3}$, rays I, 7 , III-III, uppermost of 3 lower detached rays equals pectoral, though as little advanced not reaching hind end of pectoral; ventral reaching base of second anal ray, rays $I, 5$, fin $1 \frac{1}{4}$ in head from snout tip.

Head brownish. Iris gray, apparently white in life. Upper half of body pale yellowish brown, lower half silvery white. Fins whitish. Upper part of pectoral largely gray black, all rays on outer surfaces whitish; in blackish area scattered small white spots and several larger below; edge of fin white all around. 
Type.-U.S.N.M. no. 98871. (1562.) D. 5135. Jolo Light, S. $46^{\circ}$ W., 11.90 miles (lat. $6^{\circ} 11^{\prime} 50^{\prime \prime}$ N., long. $121^{\circ} 8^{\prime} 20^{\prime \prime}$ E.), vicinity of Jolo. In 161 fathoms. February 7, 1908. Length $175 \mathrm{~mm}$.

Remarks.-Very close to Lepidotrigla kishinouyei Snyder, which also has the dark area of the pectoral fin spotted with white, but only the lower half of this area. In the present species the white spots are more variable and scattered over the entire dark area. L. punctipectoralis has a shorter pectoral, reaching $21 / 2$ to caudal base. In the specimen before me of L. kishinouyei, as well as in Snyder's figure of the type, the pectoral reaches half way to the caudal base.

Also a paratype, U.S.N.M. no. 98980. (2944.) D. 5392. Tubig Point, N. $49^{\circ}$ E., 5 miles (lat. $12^{\circ} 12^{\prime} 35^{\prime \prime}$ N., long. $124^{\circ} 2^{\prime} 48^{\prime \prime}$ E.), between Samar and Masbate. In 135 fathoms. March 13, 1909. Length $160 \mathrm{~mm}$.

(punctus, spot+pectoralis, pectoral.)

LEPIDOTRIGLA MACROBRACHIUM, new species

Figure 52

Depth $32 / 3$ (in length from snout tip); head $21 / 2$, width $13 / 4$. Snout $22 / 5$ in head; eye $32 / 5,11 / 4$ in snout, greatly exceeds interorbital; maxillary reaches $4 / 5$ to eye, length $2 \frac{2}{3}$ in head; mouth width $2 \frac{1}{4}$; teeth minutely villiform, in narrow band in each jaw, none on palate; interorbital $6 \frac{2}{3}$, very deeply concave. Gill rakers $0+9$, of which lowest 3 very small rudiments; longest $31 / 2$ in eye, $1 \frac{1}{4}$ in gill filaments, which $1 \frac{1}{2}$ in eye.

Pair of short, broadly triangular rostral spines, length 3 in eye, their edges denticulate; 2 strong antero-supraorbitals each side, also 2 close set strong postero-supraorbitals on little prominence followed by deep transverse groove, forming deep notch in upper profile of head; pair of moderate occipital spines; postocular keel terminated by spine posteriorly; suprascapular spine rather small, strong; suborbital stay with low ridge only across preopercle, ending in small short spine at preopercle angle on margin; opercle with small spine nearly level with lower edge of eye; humeral plate with long pointed spine, besides small obtuse spine on upper part of edge.

Scales 44 in lateral line to caudal base; 2 above opposite second dorsal origin, 14 below; 5 predorsal. Chest, breast, prepectoral region and area narrowly behind bases of paired fins naked. Caudal largely scaly, at least basally. Along dorsal bases 22 bony plates, each bearing strong spine, of these 9 along base of first dorsal. Scales in lateral line enlarged and narrowly imbricated; each tube simple. Scales with 5 or 6 basal radiating striae; 9 or 10 strong, short, apical denticles; circuli moderate, obsolete apically. 
D. IX-14, front edge of first spine serrated, second spine $17 / 8$ in head, seventh ray $22 / 5 ; \mathrm{A}$. 14 , I, seventh ray $32 / 5$; caudal $1 \frac{2}{5}$, concave behind; least depth of caudal peduncle 2 in eye; pectoral reaches $1 \frac{1}{6}$ to caudal base, length $13 / 4$ in fish from snout tip to caudal base, uppermost of 3 lower detached rays $13 / 5$ in upper section of fin, rays II, 6, III-III; ventral rays I, 5, reach third anal ray, fin $1 \frac{1}{3}$ in head.

Pale brown on head, whitish below. Body light brown on upper half, lower half white, with line of demarcation distinct. Iris pale, whitish, gray above. Long pectoral largely gray black, marked with very numerous, variable white round spots, margin of fin most all around white, and on outer face each ray edged narrowly with white. Fins otherwise all whitish.

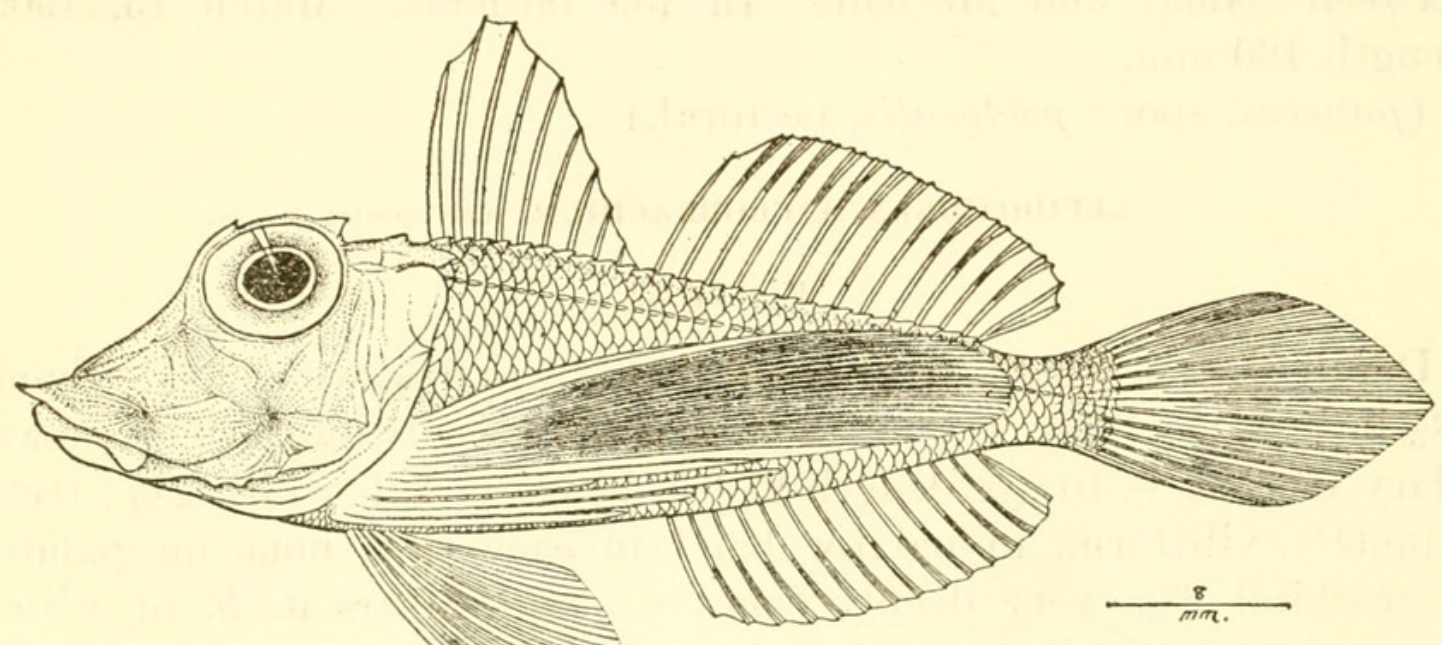

H.W.F. del.

Figure 52.-Lepiadotrigia macrobrachium, new species. Type.

Type.-U.S.N.M. no. 98882. (4388.) D. 5432. Corandagos Island (NW.), N. $30^{\prime \prime}$ E., 5.7 miles (lat. $10^{\circ} 37^{\prime} 50^{\prime \prime}$ N., long. $120^{\circ} 12^{\prime}$ E.), eastern Palawan and vicinity. In 51 fathoms. April 8, 1909. Length $64 \mathrm{~mm}$.

Remarles.-Approaches Lepidotrigla japonica (Bleeker) of Japan, but that species with shorter pectoral largely uniformly blackish, smaller scales, and less prominent armature. Known only from the type.

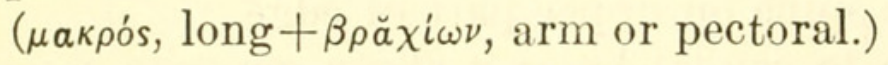

\section{PACHYTRIGLA, new genus}

\section{Type--Pachytrigla marisinensis, new species.}

Body elongately ovoid, compressed, tapers back evenly from head. Head short, deep, front profile steep. Snout moderate. Eye large, high, largely in front of second half of head. Mouth low, short, broad. Maxillary not reaching below eye. Teeth minute, in bands in jaws, none on palate. Interorbital deeply concave, bounded by 
notch or groove posteriorly and along upper postocular. Gill rakers short, strong points. Gill opening large, extends well forward or opposite middle of snout. Pair of broad, triangular rostral spines. Humeral spine well developed, others small or obsolete. Scales very firmly adherent, regular. Row of strong spiny bucklers along bases of dorsals, those of first dorsal flat, asperous, their hind edges dentate, which gives place to a large single spine along base of second dorsal. Scales of lateral line anteriorly deep, narrowly imbricated and much deeper than posterior scales. First dorsal half length of second. Anal opposite second dorsal and similar. Caudal moderate, truncate. Pectoral short, reaches front of anal. Ventral little shorter than pectoral.

In this genus, which I separate from Lepidotrigla, the anterior bucklers along the base of the first dorsal are flattened and their hind edges dentate. In Lepidotrigla these bucklers all form a keel, like those along the base of the second dorsal, each bearing a single large spine. Lepidotrigla also differs further in that the broad rostral spines are more or less spinigerous, entire in Pachytrigla.

( $\pi$ ă $\chi^{\prime} s$, thick + Trigla.)

\section{PACHYTRIGLA MARISINENSIS, new species}

Figure 53

Depth 4 in length from snout tip; head $31 / 8$, width $12 / 5$. Snout $2 \frac{1}{10}$ in head, eye 4, 2 in snout, $1 \frac{1}{110}$ in interorbital; maxillary reaches $4 / 5$ to eye, length $31 / 4$ in head; mouth width $22 / 5$; band of minute villiform teeth in each jaw, none on palate; interorbital $31 / 8$, deeply depressed concavely. Gill rakers $0+9$, low points, lower 4 mere rudiments; longest $2 / 3$ of gill filaments, which $3 \frac{1}{5}$ in eye.

Two broad, flat, triangular rostral spines, length $1 \frac{1}{2}$ in eye; supraorbital ridge with slight notch over hind eye edge; broad, strong suprascapular spine, length half of eye; ridge of suborbital stay very feeble, only evident below eye, without spine at preopercular angle; very small, short opercular spine, below lower eye edge; large triangular humeral plate ending in a slender pointed spine 3 in head.

Scales 56 in lateral line to caudal base; 4 above until opposite second dorsal origin, 16 below to anal origin; 7 predorsal. Chest, breast, and region rather narrowly behind paired fins naked, also prepectoral region. Most all of caudal finely scaled, though more densely so basally. Along dorsal bases 24 strong bucklers, first 8 along spinous dorsal at first broad with their hind edges with several serrae which progressively or at second fin form but a single strong spine to each buckler. Lateral line conspicuous, rather high $36541-38-6$ 
and straight, first tubes as 6 branches which diminish to a simple branch on posterior scales. Scales with 4 or 5 basal radiating striae; 12 to 20 short broad apical denticles; circuli fine, obsolete or ends abruptly terminally.

D. IX-16, I, third spine $22 / 5$ in head, fourth ray $33 / 4$; A. 16 , I. sixth ray 4 ; caudal $12 \frac{1}{3}$, truncate, only slightly emarginate as contracted; least depth of caudal peduncle $12 / 5$ in eye; pectoral reaches front part of anal or $23 / 5$ to caudal base, rays I, 6, IV-III, fin 11/6 in head; ventral $1 \frac{1}{4}$, rays I, 5 .

Pale brown above, under half of body whitish. Iris pale, evidently white in life. Upper section of pectoral largely blackish gray, especially terminally, edge all around whitish and each ray edged with white.

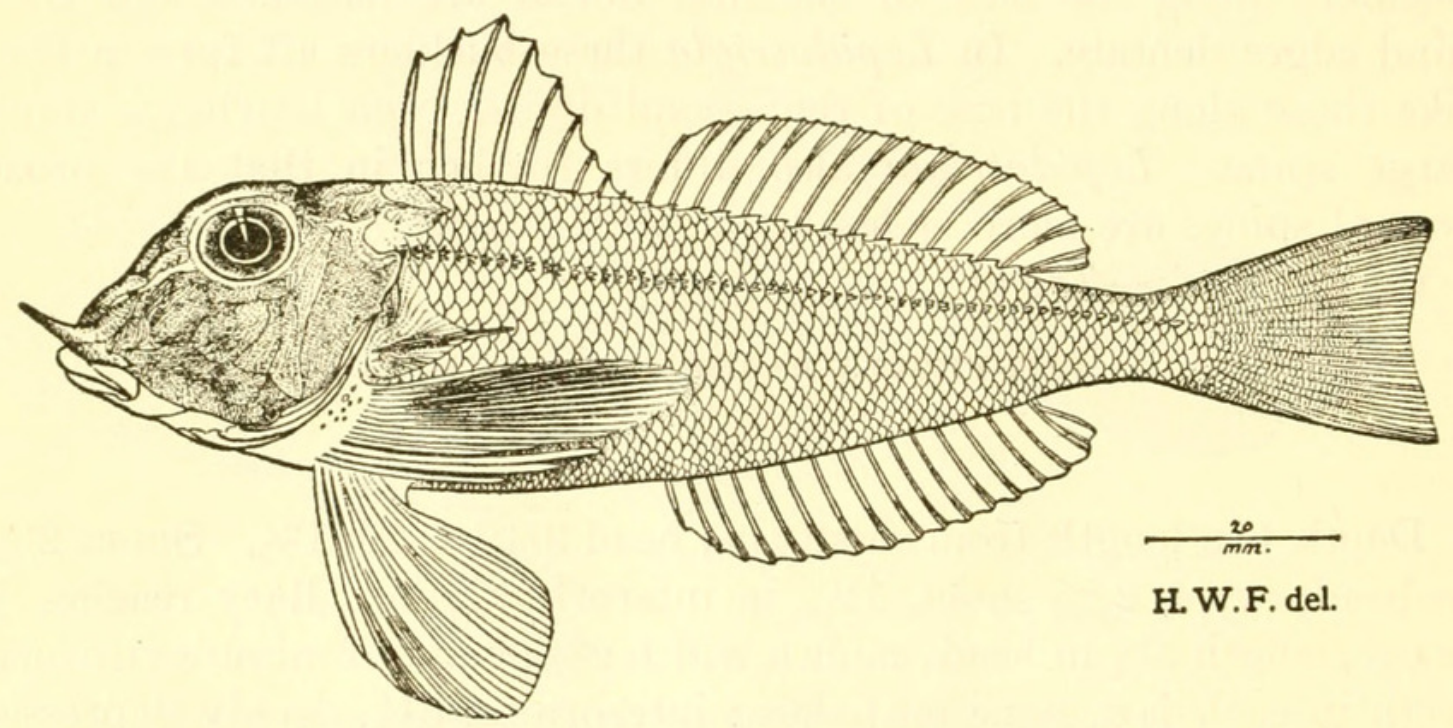

Figure 53.-Pachytrigla marisinensis, new genus, new species. Type.

Type.-U. S. N. M. no. 98867. (2694.) D. 5302. Lat. $21^{\circ} 42^{\prime}$ N., long. $114^{\circ} 50^{\prime}$ E., China Sea. In 38 fathoms. August 9, 1908. Length $147 \mathrm{~mm}$.

Known only from the type.

(Named for the China Sea.)

\section{BOVITRIGLA, new genus}

\section{Type.-Bovitrigla acanthomoplate, new species.}

Body elongately ovoid, well compressed. Head rather large, deep, compressed. Snout little less than head, its front upper profile straight. Eye large, well impinging on upper profile, largely within front of last half of head. Mouth low, nearly horizontal. Maxillary not reaching eye. Teeth minute, in fine bands in jaws, feeble short band on vomer, none on palatines. Interorbital broad, deeply concave. Pair of strong, acuminate rostral spines, directed forward, nearly long as eye. Small postero-supraorbital spine. Long, strong, suprascapular spine. Similar humeral spine. Ridge of suborbital 
stay feeble, ends in short spine at angle of preopercle. Opercular spine small. Scales small, firmly adherent, hastate and each ending in an apical spine. Patch of scales across breast. Row of imperfect scabrous plates along each side of first dorsal base, none along second dorsal. Lateral line distinct, complete, little high along side of body. Dorsal with 8 spines, but little shorter than soft fin. Anal opposite to and like soft dorsal, origin little advanced. Caudal moderate, but little emarginate. Pectoral long, reaches little over half way to caudal. Ventral reaches vent.

Related to Pterygotrigla Waite, 1899, but that genus with a very short suprascapular spine, shorter rostral spines, and no posterosupraorbital spines.

Pterygotrigla ryukyuensis Matsubara and Hiyama, 1932, may belong in the present genus, rather than in Pterygotrigla, as here understood. Its squamation is not described, and judged from the figure the scales would appear to be rounded rather than ending in an apical spine as in Bovitrigla. The condition of the breast is not given.

Quite likely Otohime Jordan and Starks, 1907, based on Trigla hemisticta Schlegel, is a valid genus. Its different physiognomy, together with the greatly enlarged and elongate opercular spine, is diagnostic.

Trigla leptacanthus Günther is evidently a member of the present genus, though it differs from the genotype in various minor items specifically.

$($ bos, bull + Trigla. $)$

\section{BOVITRIGLA TRIACANTHUS (Günther)}

Trigla triacanthus GÜNTHER, Report on the scientific results of the voyage of H. M. S. Challenger, vol. 1, pt. 6 , p. 42, pl. 18, fig. B, 1880 (type locality, Ki Islands, in 129 fathoms).

Differs from Bovitrigla acanthomoplate in the greatly shorter humeral spine, narrower interorbital, shorter maxillary, uppermost of lower 3 detached pectoral rays reaching only well short of anal or perhaps only to vent, and its details of coloration. Günther does not mention the scales on the breast, if present, and his figure fails to reveal any.

BOVitrigla ACANTHOMOPLATE, new species

Figure 54

Depth 4 in body measured from snout tip; head $23 / 5$, width $13 / 4$. Snout $21 / 8$ in head from snout tip; eye $37 / 8,17 / 8$ in snout, $11 / 8$ in interorbital; mouth width 3 ; maxillary reaches $3 / 4$ to eye, length $27 / 8$ in head from snout tip; band of very fine villiform teeth in each 
jaw; small, short transverse band of minute, feeble teeth on vomer; palatines toothless; interorbital deep, broadly depressed concavely. Gill rakers $1+9$, of which lowest 4 mere short, low, weak rudiments; lanceolate, subequal with gill filaments or 3 in eye.

Pair of broad, flat, divergent rostral spines, extended forward, long as eye; small postero-orbital spine; long, slender suprascapular spine, flaring out and back, about 3 in head; ridge of suborbital stay but feeble keel, ends in small sharp spine at preorbital angle reaching gill opening; slender, pointed opercular spine, little below level of eye; long humeral spine horizontal, about 3 in head.

Lateral line with 50 scales in its course to caudal base; 10 above, 22 below; 10 predorsal. Row of 9 more or less ill defined scabrous bucklers along each side of base of first dorsal. Body and

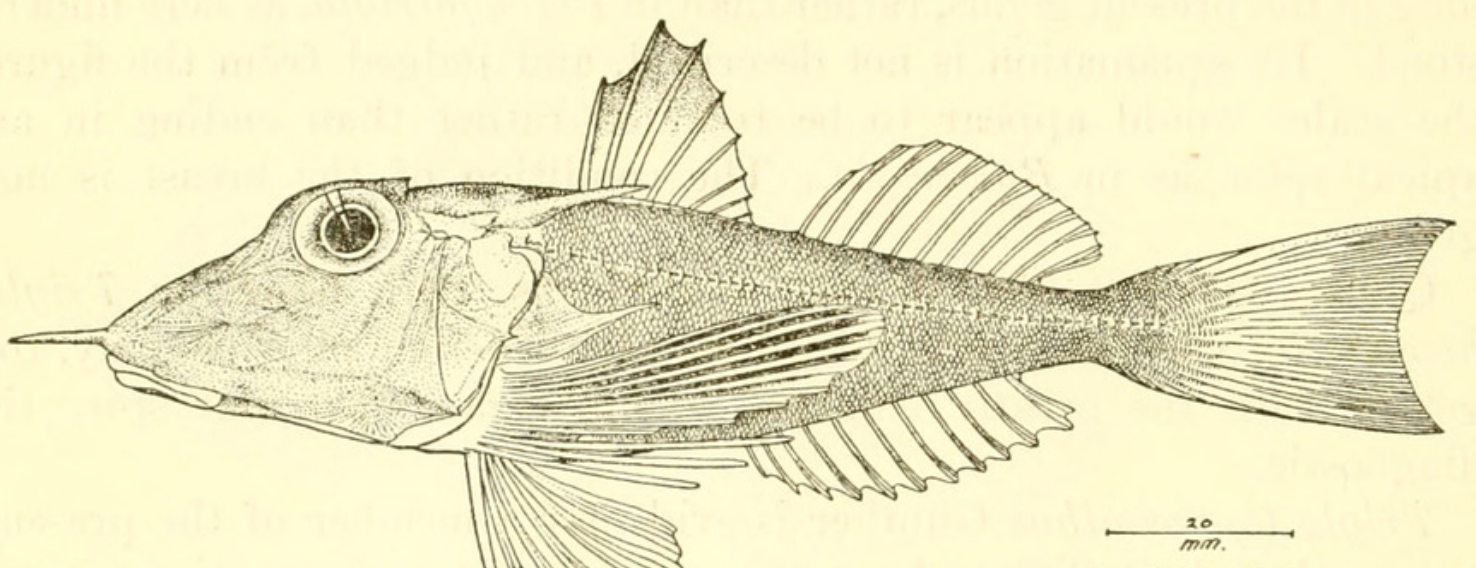

H. W. F. del.

Figure 54.-Bovitrigla acanthomoplate, new genus, new species. Type.

tail largely with fine scales, some extending on base of caudal; middle and sides of breast with small scales, chest, prepectoral region and area around bases of paired fins naked, though belly covered with fine close set scales. Scales small, pear-shaped, each ending in a single apical spine; basal portion trilobate; circuli imperfect, uneven.

D. VIII-11, I, second spine $2 \frac{1}{4}$ in head, fourth ray $23 / 4$; A. I. 11 , I, eighth ray $3 \frac{1}{2}$; caudal $1 \frac{1}{2}$, hind edge obliquely and slightly emarginate; least depth of caudal peduncle 2 in eye; pectoral $1 \frac{1}{10}$ in head, rays II, 5, V-III, uppermost of 3 detached rays $12 / 5$ in upper section of pectoral fin; ventral $13 / 5$ in head, rays I, 5 , fin reaches vent.

Brown, with traces of gray or silvery sheen on sides of head. Under surface of head, chest, breast, prepectoral region and belly silvery white. Iris pale, evidently white. Fins all pale or light. First dorsal with first to third membranes on outer half dull brownish. Second dorsal marginally brownish. Upper part of pectoral, 
over greater part of its upper section gray black, edge pale or whitish all around, and outer face of fin edge of each ray narrowly whitish. Three detached rays and front margin of ventral broadly whitish.

Type-U.S.N.M. no. 98869. (2223.) D. 5519. Point Tagolo Light, S. $71^{\circ}$ W., 8.7 miles (lat. $8^{\circ} 47^{\prime}$ N., long. $123^{\circ} 31^{\prime} 15^{\prime \prime}$ E.), vicinity of northern Mindanao. In 182 fathoms. August 9, 1909. Length $150 \mathrm{~mm}$.

Remarks.-Apparently related to Pterygotrigla ryukyuensis Matsubara and Hiyama 1932, Ryukyu Islands, based on a specimen 260 $\mathrm{mm}$ long. That species differs noticeably in its much broader and shorter rostral spines, more narrow predorsal plate, absence of the postero-supraorbital spine, shorter and less divergent suprascapular spines and shorter pectoral.

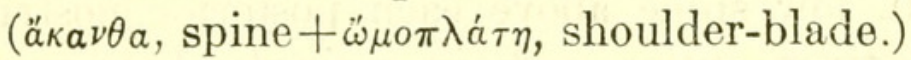

\section{DIXIPHISTOPS, new genus}

Type-Dixiphistops megalops, new species.

Body elongately ovoid, well compressed. Head deep, moderate, compressed. Snout moderate, depressed, much shorter than rest of head. Eye very large, well impinging on upper profile, center little behind middle in head length measured from snout tip. Mouth moderate, terminal, low, nearly horizontal. Maxillary reaches opposite front of eye, well expanded behind and slips below preorbital. Interorbital deeply concave. Nostrils small, well separate and hind pair midway in snout. Gill rakers long, lanceolate. Gill opening wide, extends forward about last fourth in snout. Head largely with surfaces of bones finely rugose striate. Each side of snout a long, flat, slender, acuminate spine, at least $2 / 3$ rest of head. Small pair of spines between posterior nostrils. Ridge of suborbital stay well marked, entire or without spines. Strong depressed spine back from each side of occiput. Opercular spine small. Rather long, slender, humeral spine. Each side of spinous dorsal 8 rugose bony bucklers, besides one close before fin. No bony bucklers along base of soft dorsal, though each ray with a small, short basal spine each side. Lateral line complete, high along side, composed of moderate tubes. Scales minute, rather irregular, and firmly adherent. Dorsal spines 7 , slender, fin $3 / 4$ of soft dorsal. Anal opposite soft dorsal, similar. Caudal little emarginate. Pectoral moderate, reaches half way to caudal base; fin in 2 sections, with lowest rays of upper section graduated short; uppermost ray of lower section little longer than upper section of fin. Ventral short, reaches vent.

( $\delta i a$, divided $+\xi i \phi o s$, sword $+\omega \psi$, appearance.) 


\section{DIXIPHISTOPS MEGALOPS, new species}

Figure 55

Depth $34 / 5$ in length from snout tip; head from snout tip (not tip of rostral extensions) $2 \frac{1}{2}$, width 2 . Snout $2 \frac{5}{5}$ in head; eye $31 / 3$, $11 / 3$ in snout, little greater than interorbital; maxillary reaches below front eye edge, expansion 3 in eye, length $22 / 5$ in head; bands of very minute, fine, villiform teeth in jaws, concealed in closed jaws; no teeth on palate; bony rostral extension on each side of end of snout $1 \frac{1}{2}$ in rest of head; interorbital 4 in head, rather deeply concave. Gill rakers $3+17$, slender, $21 / 2$ in eye; 2 above and 7 below very short, low rudiments; gill filaments $1 / 5$ of eye or $2 / 5$ of gill rakers.

A very low, blunt, obtuse, supraorbital posterior knob; long, strong spine projecting back each side of occiput reaching spinous dorsal origin; very small, low spine above each posterior nostril; keel of suborbital stay distinct, entire, ends in a single short spine

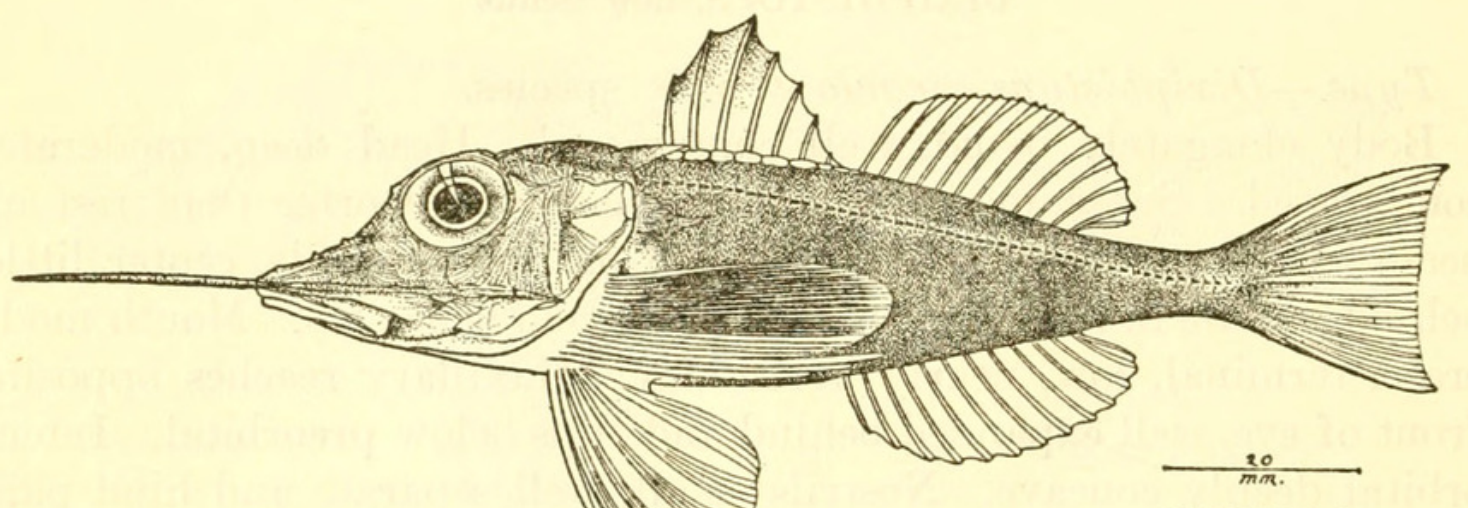

H.W.F. del.

Figure 55.-Dixiphistops megalops, new genus, new species. Type.

behind at angle of preopercle edge, spine not quite reaching gill opening; opercle with small spine, level with lower part of eye; large, slender humeral spine, little inclined upward and backward, length $1 \frac{1}{4}$ in eye. Row of rugose striate bucklers along base of spinous dorsal, one also just in front of fin invading about $1 / 3$ of predorsal space, which otherwise finely scaled. Soft dorsal without bucklers though on each side of base a very small, inconspicuous, short spine, very evident as the finger is drawn along the base of the fin.

Scales minute, irregular, largely little or nonimbricate; chest, breast, prepectoral region, and space behind bases of paired fins naked. Lateral line distinct, tubes 53 in its course to caudal base. Bones of head all more or less finely and smoothly rugose striate.

D. VII-12, third spine $22 / 3$ in head from snout tip, third ray $3 \frac{1}{10}$; A. 12 , I, eighth ray $3 \frac{3}{7}$, fin edge not notched; caudal $12 / 3$, hind edge little concave and end of each lobe pointed; least depth of caudal peduncle 2 in eye; pectoral moderate, reaches front part of anal, fin 
length $11 / 5$ in head, rays I, 8, IV-III, uppermost of 3 lower detached rays slightly longer than upper section of fin; ventral inserted little before pectoral base, with spine and 5 rays, fin length $1 \frac{1}{3}$ in head from snout tip.

Very pale or light brown. Iris light yellowish, evidently whitish in life. Back little more brownish than belly, below more whitish. Fins all more or less pale to whitish. Spinous dorsal whitish, anterior membranes terminally dark brown. Pectoral dark gray or brown medially, border pale all around.

Type.-U.S.N.M. no. 98879. (3679.) D. 5441. San Fernando Point Light, S. $87^{\circ}$ E., 18.7 miles (lat. $16^{\circ} 38^{\prime}$ N., long. $119^{\circ} 57^{\prime} 18^{\prime \prime}$ E.), west coast of Luzon. In 186 fathoms. May 10, 1909. Length $146 \mathrm{~mm}$.

Diagnosis in the genus.

$\left(\mu^{\prime} \gamma \breve{a} s\right.$, large $+\breve{\omega} \psi$, eye.)

\section{DIXIPHISTES, new genus}

Type.-Dixiphistes macrorhynchus, new species.

Body elongately ovate, well compressed. Head long, compressed, attenuated. Snout long, extended, so that muzzle more than half of head. Eye large, elevated, impinging on upper profile, anteriorly in posterior half of head. Mouth rather small, terminal, low, nearly horizontal. Maxillary not quite reaching $3 / 4$ to eye, well expanded behind and slips below preorbital. Interorbital deeply concave. Nostrils small, weil separated and hind pair at first $2 / 5$ in snout. Gill rakers long, lanceolate. Gill opening wide, extends forward well before eye. Head largely with surfaces of bones finely rugose striate. Each side of snout a long, flat, slender, acuminate spine, at least $2 / 3$ rest of head. Ridge of suborbital stay well marked, entire or without spines. Strong spine back from each side of occiput. Opercular spine small. Large humeral spine, with broad, flat, striate basal portion. Each side of spinous dorsal 8 rugose bony bucklers, besides large one just before fin. No bony bucklers along base of soft dorsal, though each ray with a small, short, basal spine each side. Lateral line complete, high along side, composed of rather large tubes. Scales minute, rather irregular, and firmly adherent. Dorsal spines 7, slender, fin little over half soft dorsal. Anal opposite soft dorsal, similar. Caudal little emarginate. Pectoral very long, reaches $3 / 5$ to caudal base; fin in 2 sections, with lowest rays of upper section graduated short; uppermost ray of lower section little longer than upper section of fin. Ventral short, reaches vent.

This very interesting genus is the extreme of the group of genera with a pair of flattened, accuminate rostral extensions forward. It 
differs in the elongated snout, with the maxillary falling well short of the eye, the uppermost ray of the lower section of the pectoral fin longer than the upper section of the fin, its armature of the head, bucklers, scales, etc.

( $\delta i a$, divided $+\xi i \phi o s$, sword.)

\section{DIXIPHISTES MACRORHYNCHUS, new species}

Figure 56

Depth $4 \frac{1}{2}$ in length from snout tip; head from snout tip (not tip of rostral extensions) $2 \frac{1}{3}$, width $24 / 5$. Snout $13 / 4$ in head; eye $43 / 4$, $23 / 5$ in snout, subequal with interorbital; maxillary reaches $2 / 3$ to eye, expansion 2 in eye, length $2 \frac{2}{3}$ in head; band of minute villiform teeth in each jaw, upper exposed when mouth closes; no teeth on palate; bony rostral extension each side of end of snout $1 \frac{1}{2}$ in rest of head; interorbital 47/8 in head, deeply concave. Gill rakers $3+13$, slender, $1 \frac{1}{2}$ in eye; gill filaments $2 / 3$ of gill rakers.

No supraorbital spines; strong, backward-projecting spine, each side of occiput reaching spinous dorsal origin; keel of suborbital stay distinct, entire, ends in single, moderate spine behind at angle of preopercle edge, spine projecting slightly behind gill opening; opercle with small spine, level with lower part of eye; large strong humeral spine, length $4 / 5$ of eye. Row of rugose striate bucklers along base of spinous dorsal, one also just in front of fin but invades only about $1 / 3$ of predorsal space, which otherwise smooth and scaleless; bucklers without any spines. Soft dorsal without bucklers though on each side of base a very small, inconspicuous, short spine, very evident if the finger is drawn along the base of the fin.

Scales minute, irregular, largely little or nonimbricate; absent from predorsal and narrow strip below bucklers of spinous dorsal, chest, breast, prepectoral and region behind bases of paired fins. Lateral line distinct, tubes 52 in its course to caudal base. Bones of head all more or less finely and smoothly rugose striate.

D. VII-I, 11, third spine 3 in head from snout tip, third ray $31 / 4$; A. 12 , I, fifth ray $41 / 2$, fin edge not notched; caudal $13 / 4$, hind edge slightly concave and end of each lobe pointed; least depth of caudal peduncle $14 / 5$ in eye; pectoral very long, reaches middle of soft anal or dorsal, fin length $23 / 4$ in fish from snout tip to caudal base; rays 10, V-III, uppermost of 3 lower detached rays slightly longer than upper section of fin; ventral inserted little before pectoral base, with spine and 5 rays, fin length $13 / 4$ in head from snout tip.

Head pale or very light brown, with traces of whitish or silvery reflections. Iris whitish, with gray. Back and body brown, with silvery or white on belly. Fins all more or less pale or whitish. 
Spinous dorsal brownish terminally. Upper section of pectoral grayish, with 4 rather ill defined transverse dark or blackish bands. Ventral with outer portions of third and fourth membranes each with a dark brown bar.

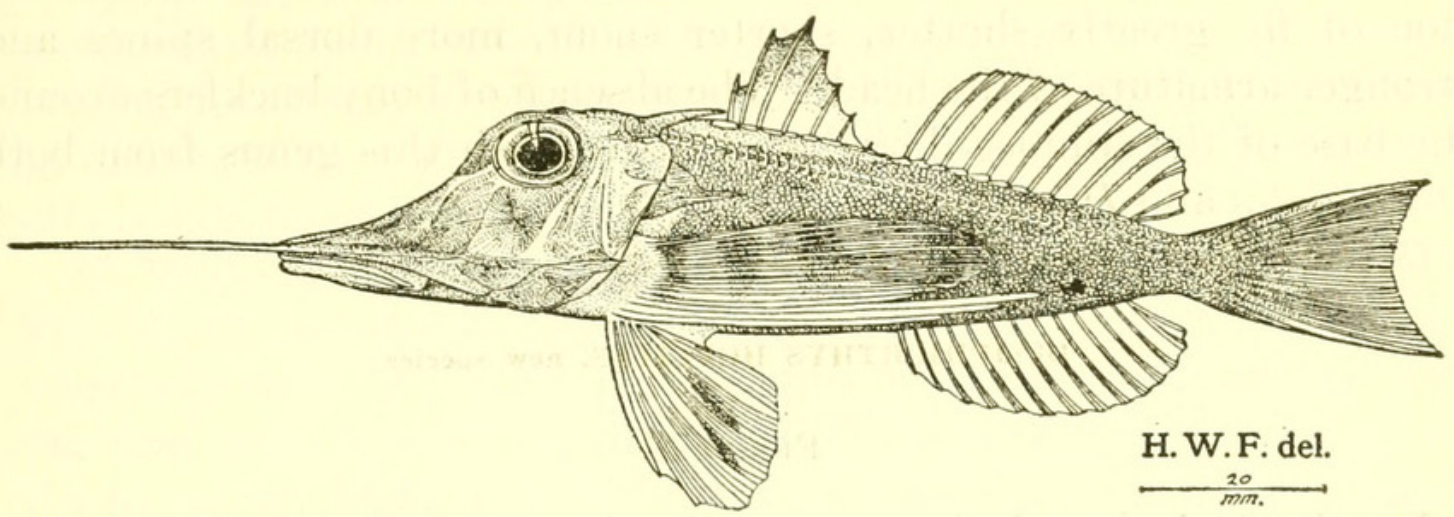

Figure 56.-Dixiphistes macrorhynchus, new genus, new species. Type.

Type-U.S.N.M. no. 98875. (2222.) D. 5519. Point Tagolo Light, S. $71^{\circ}$ W., 8.7 miles (lat. $8^{\circ} 47^{\prime}$ N., long. $123^{\circ} 31^{\prime} 15^{\prime \prime}$ E.). In 182 fathoms. August 9, 1909. Length $159 \mathrm{~mm}$.

Diagnosis contained in that of its genus.

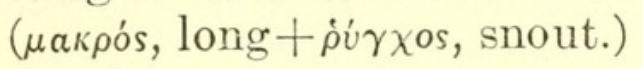

\section{DIXIPHICHTHYS, new genus}

Type.-Dixiphichthys hoplites, new species.

Body elongately ovate, well compressed. Head moderate, rather well compressed. Snout moderate, depressed, shorter than rest of head. Eye moderate, elevated, impinging on upper profile, largely with anterior portion in posterior half of head. Mouth moderate, terminal, low, nearly horizontal. Maxillary not quite reaching eye, well expanded behind and slips below preorbital. Interorbital deeply concave. Nostrils small, well separated and posterior midway in snout length. Gill rakers long, lanceolate. Gill opening wide, extends forward well before eye. Head largely with surfaces of bone rugose striate. Each side of snout a long, flat, slender, acuminate spine, at least little over half of rest of head. Ridge of suborbital stay well marked, entire, or without spines. Long, strong spine back from each side of occiput. Opercular spine small. Short, strong humeral spine. Along base of spinous dorsal row of scabrous scales, small and each with short pointed spine. No bucklers along base of soft dorsal, though each ray with a small, short basal spine each side. Lateral line complete, high along side, composed of rather large tubes. Dorsal spines 8, slender, fin little less than half of soft dorsal. Anal opposite soft dorsal, similar. Caudal nearly truncate. Pectoral very long, reaches $4 / 5$ to caudal base; fin in 2 sections, with 
lowest rays of upper section graduated short; uppermost ray of lower section little more than half length of upper section of fin. Ventral reaches vent.

Close to Dixiphistes but with a longer pectoral, though lower section of fin greatly shorter, shorter snout, more dorsal spines and stronger armature of the head. The absence of bony bucklers around the base of the spinous dorsal will distinguish this genus from both Dixiphistes and Dixiphistops.

( $\delta i a$, divided $+\xi i \phi_{o s}$, sword $+i \chi \theta \dot{s}$, fish.)

\section{DIXIPHICHTHYS HOPLITES, new species}

Figure 57

Depth $32 / 3$ in length from snout tip; head from snout tip (not tip of rostral extensions) $2 \frac{2}{3}$, width $17 / 8$. Snout $21 / 5$ in head; eye $4,13 / 4$ in snout, slightly greater than front part of interorbital; maxillary reaches $7 / 8$ to eye, expansion $21 / 3$ in eye, length $2 \frac{1}{5}$ in head; bands of very minute, fine, villiform teeth in jaws, concealed in closed jaws; no teeth on palate; bony rostral extension on each side of end of

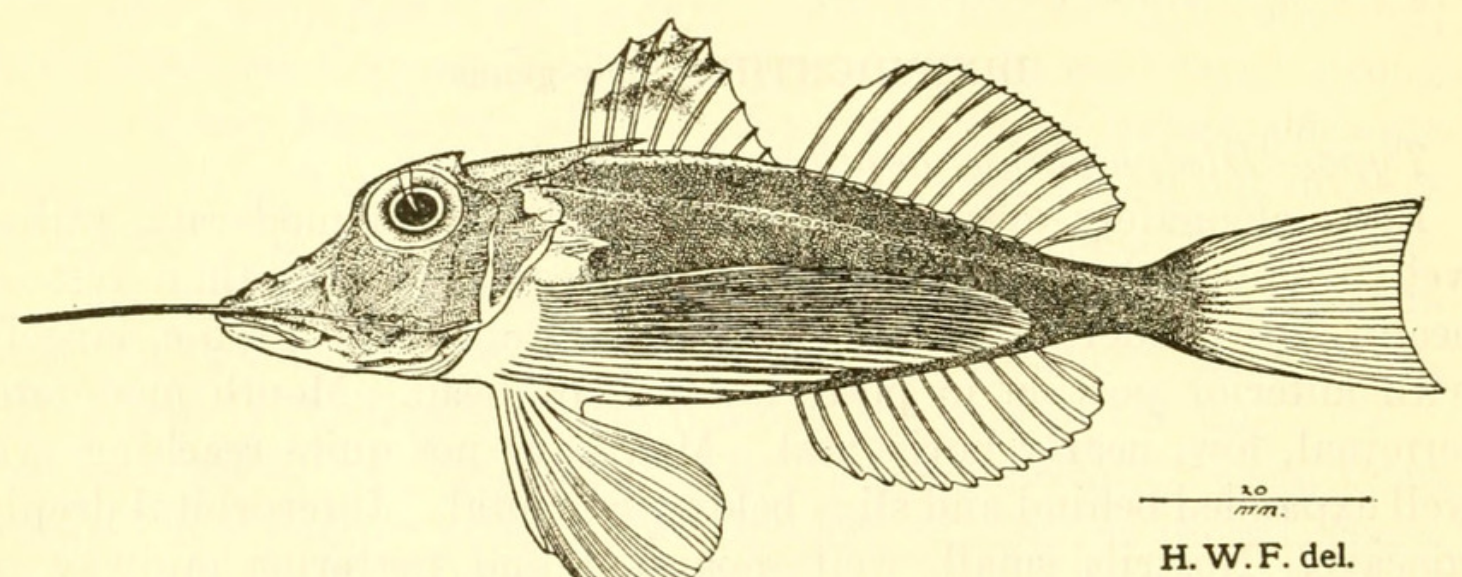

Figure 57.-Dixiphichthys hoplites, new genus, new species. Type.

snout 2 in rest of head; front part of interorbital width $4 \frac{1}{8}$ in head, rather deeply concave. Gill rakers $4+13$, of which 2 above low rudiments; gill rakers $21 / 2$ in eye; gill filaments $3 / 5$ of gill rakers.

Pair of very short, low, sharp, wide set spines between hind nostrils; broad, strong, low, obtuse postero-supraorbital spine; long, strong spine, projects back each side of occiput and reaches base of second or third dorsal spine; keel of suborbital stay distinct, entire, ends in a single, short, low spine at preopercle angle, not reaching: gill opening; opercle with small spine, level with lower part of eye; short, strong, pointed, humera! spine, little inclined, $1 \frac{1}{3} 3$ in eye. Row of small, scabrous scales along each side of base of spinous dorsal, 
each bearing a small, low spine. Soft dorsal with a low, inconspicuous, short spine each side basally of each ray, very evident as the finger is drawn along the base of the fin.

Scales very minute, in oblique rows along side of body, chest, breast, prepectoral, spare around bases of paired fins, and narrow loop around front of spinous dorsal naked. Lateral line distinct, tubes 50 in its course to caudal base. Bones of head all minutely rugose striate, rough velvety to touch.

D. VIII-12, I, fourth spine $31 / 3$ in head from snout tip, fifth ray $21 / 4$; A. 12 , eighth ray $22 / 5$, fin edge not notched; caudal $12 \%$, its hind edge very slightly concave; least depth of caudal peduncle $13 / 4$ in eye; pectoral long, reaches $1 \frac{1}{4}$ to caudal, fin length 2 in fish from snout tip to caudal base, rays I, 8, IV-III, uppermost of 3 lower detached rays $13 / 5$ in upper section of fin; ventral inserted little before pectoral base, with spine and 5 rays, fin length $12 \%$ in head from snout tip.

Pale or light brownish, most of head and belly whitish. Iris pale, evidently white in life. Spinous dorsal with membranes brownish terminally. Membranes of upper section of pectoral, connecting branched rays, gray black, edge of fin rather narrowly whitish.

Type.-U.S.N.M. no. 98874. (4143.) D. 5516. Port Tagolo Light (Mindanao), S. $80^{\circ}$ W., 9.7 miles (lat. $8^{\circ} 46^{\prime}$, N., long. $123^{\circ} 32^{\prime} 30^{\prime \prime}$ E.), vicinity of northern Mindanao. In 175 fathoms. August 9, 1909. Length $134 \mathrm{~mm}$.

Also paratype, U.S.N.M. no. 98982. (1435.) D. 5412. Lauis Point Light, N. $21^{\circ}$ E. 5.5 miles (lat. $10^{\circ} 9^{\prime} 15^{\prime \prime}$ N., long. $123^{\circ} 52^{\prime}$ E.), between Cebu and Bohol. In 162 fathoms. March 23, 1909. Length $128 \mathrm{~mm}$.

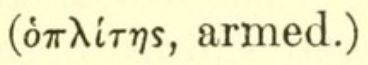

\section{Family PERISTEDIIDAE}

GARGARISCINAE, new subfamily

Type genus, Gargariscus H. M. Smith. Upper jaw with teeth. lower toothless.

Includes Gargariscus and Heminodus.

\section{Genus GARGARISCUS H. M. Smith}

GARGARISCUS PRIONOCEPHALUS (Duméril)

Peristedion undulatus Weber, $1913=$ Gargariscus semidentatus $\mathbf{H}$. M. Smith, 1917, both to fall with Peristethidion prionocephatum Duméril 1868.

Of $G$. semidentatus H. M. Smith I have examined the type and other Philippine material. 


\section{Genus HEMINODUS H. M. Smith}

HEMINODUS PHILIPPINUS H. M. Smith

The type and other Philippine material examined.

\section{Subfamily PeRISTEdinae}

Type genus, Peristedion. Both jaws toothless. Includes Peristedion, Satyrichthys, Nemaperistedion, and Scaticus.

\section{Genus PERISTEDION Lacépède}

PERISTEDION AMBLYGENYS, new species

\section{Figure 58}

Depth $5 \frac{4}{5}$ in body measured from snout tip inside rostral extensions; head $31 / 8$, width $12 / 5$. Snout $21 / 4$ in head; eye $4,12 / 3$ in snout, little greater than interorbital; maxillary extends $4 / 5$ to eye, length 3 in head; mouth width $2 \pi / 8$; barbel $2 \frac{1}{4}$, with 6 tufts of several small filaments; anteriorly each side of mandibular symphysis tuft of small filaments and 4 tufts on inner edge of each ramus of lower jaw anteriorly; mouth endentulous; interorbital $4 \frac{1}{5}$ in head, deeply concave. Gill rakers $4+19$, lanceolate, 3 in eye, twice gill filaments.

Pair of attenuated, long, flat, rostral extensions, long as snout, rather narrow interspace $4 / 5$ width of either extension; single, strong, low, postero-supraorbital spine, keel extending back with broad, obtuse parietal angle and ends in large, strong, erect occipital spine; postocular keel ends in blunt suprascapular spine; opercle with pointed spine forming long keel forward long as eye; keel of suborbital stay with undulous edge though without any spines and simply obtuse posteriorly.

From above gill opening $35+1$ bony lateral plates; 4 rows of diminishing spiniferous plates on trunk; spines all large, strong, erect and surfaces of plates rugose; hind pair of plates on belly before vent $13 / 4$ length of front pair; are of 5 rather poorly developed scutes from over gill opening downward.

D. VIII, 20, third spine $3 \frac{1}{10}$ in head, fourth ray $3 ;$ A. 22 , eighth ray $33 / 4$; caudal 3 ? (damaged) ; least depth of caudal peduncle $31 / 2$ in eye; pectoral $2 \frac{1}{5}$ in head, rays I, 11 -II, upper detached ray $12 / 5$ in head or reaches base of fifth anal ray; ventral rays I, 5, fin 2 in head or reaches vent; vent with papilla $1 / 3$ of eye.

Light brown, whitish below. Iris gray. Spinous dorsal with blackish margin above and soft dorsal with black marginal line. Pectoral whitish, with blackish terminally and transverse dark brown band. 
Type-U.S.N.M. no. 98870. (24377.) D. 5442. San Fernando Point Light, N. $39^{\circ}$ E., 8.4 miles (lat. $16^{\circ} 30^{\prime} 36^{\prime \prime}$ N., long. $120^{\circ} 11^{\prime} 6^{\prime \prime}$ E.), west coast of Luzon. In 45 fathoms. May 10, 1909. Length 162 $\mathrm{mm}$ to end of broken caudal.

Remarks.-Also a series of Philippine specimens in 108 to 445 fathoms.

Differs from Peristedion nierstraszi, and $P$. picturatum in the supraorbital and occipital spines higher, snout longer, and the upper detached pectoral ray reaches front of anal. It agrees in the rostral extensions spineless and the dorsal spines 6 .

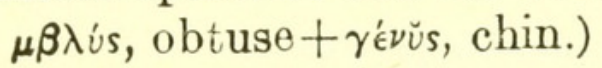

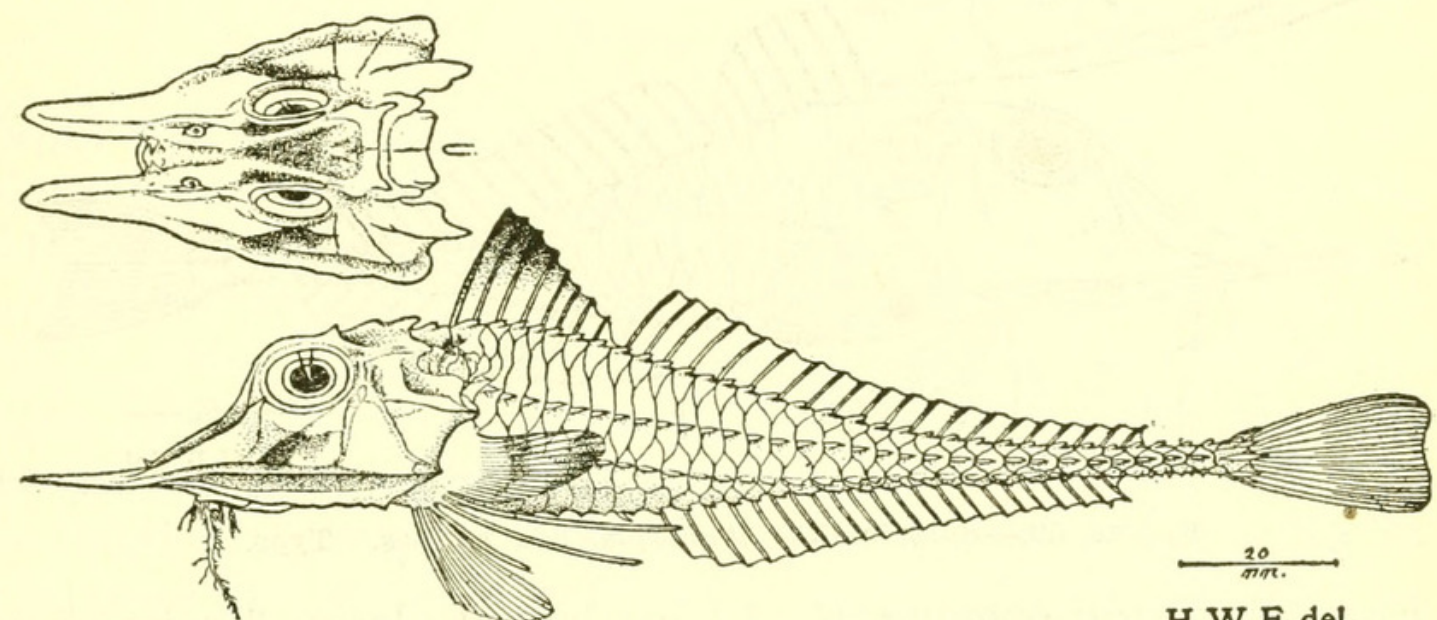

H.W.F. del.

FigUre 58.-Peristedion amblygenys, new species. Type.

\section{Genus SATYRICHTHYS Kaup}

\section{SATYRICHTHYS CLAVILAPIS, new species}

\section{Figure 59}

Depth $42 / 3$ in length measured from -snout tip inside rostral extensions; head $2 \frac{1}{3}$, width $1 \frac{1}{2}$. Snout $1 \frac{9}{10}$ in head; eye $5 \frac{1}{8}, 23 / 4$ in snout, equals interorbital; maxillary extends $4 / 5$ to eye, length $21 / 4$ in head; mouth width $2 \frac{1}{3}$; barbel $37 / 8$, with 3 long filaments; pair of rather long lower mental filaments, one each side of mandibular symphysis, though no others; no teeth; interorbital 51/4 in head, deeply concave, superciliary ridges broad and elevated. Gill rakers $6+18$, of which 3 or 4 above and below small rudiments; length 3 in eye; gill filaments $3 / 5$ of gill rakers.

Pair of broad, flattened, thin, attenuated, rostral extensions, longer than eye or equal to postocular space, interspace equals basal width of either extension; single and rather large postero-supraorbital spine each side, with keel leading back to large, strong occipital spine, 1/3 of eye; postocular keel ends in blunt, short suprascapular spine; 
single, small, inconspicuous median spine on snout at last fourth its length; opercular spine small, slender, little below level of eye, with slight keel forward so its length equals eye; ridge of suborbital stay broad, flat keel, with finely serrate or denticulate edge, ending in long slender spine at angle of preopercle long as eye and with small short prebasal denticle externally, also preopercle spine reaching very little beyond base of uppermost pectoral ray or about $1 / 8$ in fin length.

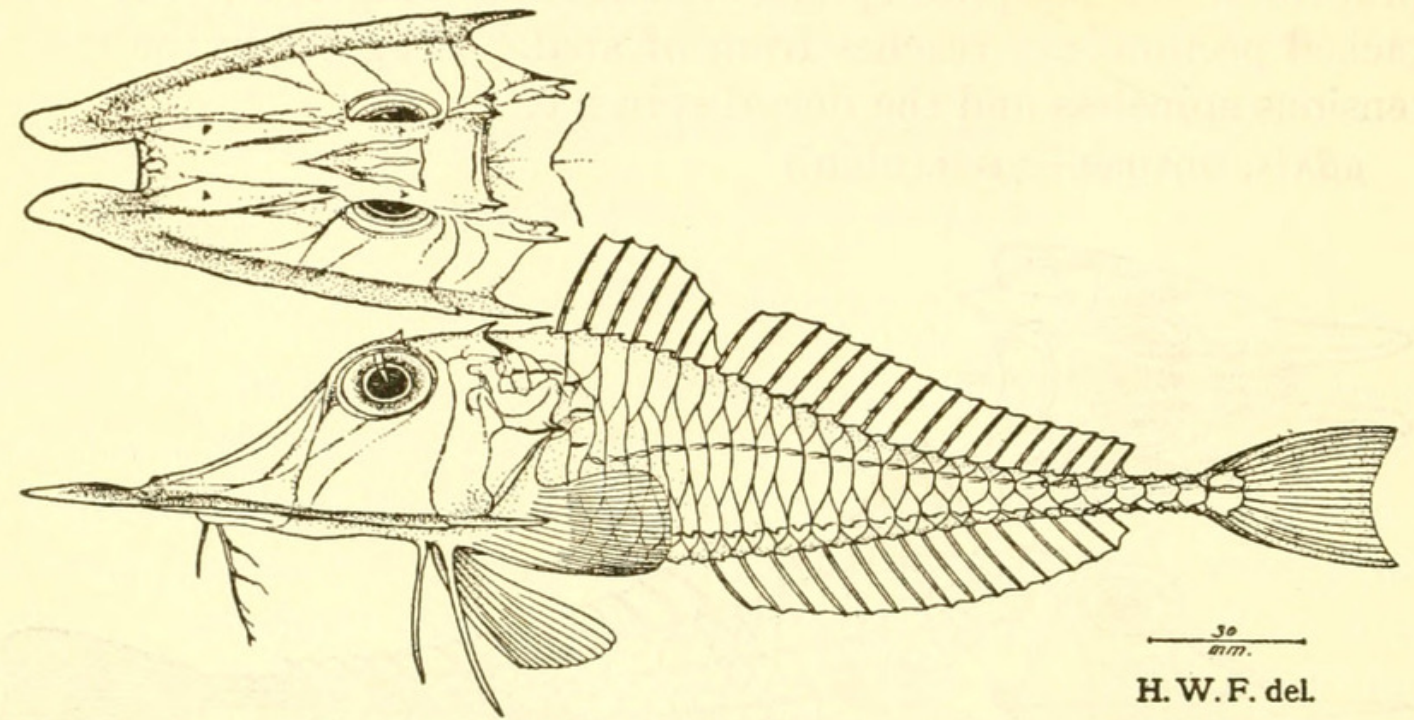

Figure 59.-Satyrichthys clavilapis, new species. Type.

From above gill opening $27+1$ bony lateral plates; 3 rows of diminishing spiniferous plates on trunk with an additional row on belly and under side of tail; spines all slender, sharp pointed, firm, and surfaces of plates rugose striate; front pair of plates on belly twice long as posterior pair close before vent; row of 3 small plates, each bearing horizontal keel ending in spine, above gill opening and subvertical row behind gill opening also of 3 small plates.

D. VII, 17 , third spine $34 / 5$ in head, third ray $43 / 5 ;$ A. 16 , fifth ray 5 ; caudal $23 / 5$, concave behind; least depth of caudal peduncle $24 / 5$ in eye; pectoral $2 \frac{9}{10}$ in head, rays $10, \mathrm{II}-\mathrm{II}$, uppermost detached ray $2 \frac{1}{5}$ in head; ventral $21 / 4$, rays I, 5 .

Brownish, under surface of body whitish. Iris pale, evidently whitish or light in color. Dorsals with spines and rays each marked with 5 blackish brown small spots; along each side of base of fins more or less dark to blackish line, broken into many variable small spots.

Type.-U.S.N.M. no. 98868. (4742.) D. 5118. Sombrero Island, S. $47^{\circ}$ E., 10 miles (lat. $13^{\circ} 48^{\prime} 45^{\prime \prime}$ N., long. $120^{\circ} 41^{\prime} 51^{\prime \prime}$ E.), Balayan Bay and Verde Island Passage. In 159 fathoms. January 21, 1908. Length $244 \mathrm{~mm}$ to end of broken rostral extensions.

Remarks.-Alsa a series of Philippine paratypes, in 37 to 394 fathoms. 
Differs from Nemaperistedion orientale in its narrower and less expanded head, longer and slenderer rostral extensions with a broader interspace, the absence of an inner or upper spine at the preopercular angle, the presence of a prebasal external small spine to the preopercular opposite the front vertical border of the preopercle, greatly shorter mandibular barbel with fewer filaments, fewer mental filaments and none along inner edges of chin externally, and in the presence of a minute frontal spine on the snout before the eye.

(clavis, key+lapis, stone; with reference to the contour of the head as viewed above suggestive of the outline of a keystone.)

\section{SATYRICHTHYS PIERCEI, new species}

\section{Figure 60}

Depth $43 / 4$ in length measured from snout tip inside rostral extensions; head $21 / 4$, width $11 / 3$. Snout 2 in head; eye $42 / 3,21 / 8$ in snout, equals interorbital; maxillary extends $4 / 5$ to eye, length $2 \frac{1}{2}$ in head; mouth width $21 / 5$; barbel $2 \frac{1}{4}$, with 8 pairs of filaments; pair of rather long lower mental filaments each side of mandibular symphysis, and outer with small accessory filament; along front part of inner edge of each mandibular ramus 3 short filaments; no teeth; interorbital $43 / 4$, deeply convex. Gill rakers $6+17$, length $31 / 5$ in eye or twice gill filaments.

Pair of flat, thin, triangular, rostral extensions, long as eye, basal width of each equal to $7 / 8$ of interspace; pair of small, erect, wide-set postnasal spines, little behind posterior nostrils or at first third in snout; single larger spine medially at last third in snout; single and rather large postero-supraorbital spine each side, keel posteriorly leading to large, strong, erect occipital spine, $2 \frac{1}{3}$ in eye; postocular keel ends in small, inconspicuous blunt end, scarcely a suprascapular spine; opercular spine slender, about level with lower edge of eye, with forward keel so its length nearly equals eye; ridge of suborbital stay trenchant, moderate, with finely serrate or denticulate edge, ending in long slender spine at angle of preopercle $11 / 5$ times eye and with short prebasal denticle externally, also preopercular spine reaching $1 / 7$ in pectoral fin.

From above gill opening $28+1$ bony lateral plates; 4 rows of diminishing spiniferous plates on trunk and tail; spines all triangular, rather small, firm, sharply pointed and surfaces rugose striate; hind pair of plates on belly before vent $14 / 5$ in front pair; are of 5 small plates over and behind gill opening.

D. VII, 16, third spine $4 \frac{1}{8}$ in head, fourth ray $34 / 5 ;$ A. 16 , fourth ray 4 ; caudal $2 \frac{1}{4}$, little concave behind; least depth of caudal peduncle $23 / 4$ in eye; pectoral $2 \frac{3}{3}$ in head, rays I, 12 , I-II, reaches oppo- 
otce anal origin, upper of lower detached rays long as upper section or pectoral; ventral reaches vent, rays I, 5 , fin $1 \frac{9}{10}$ in head.

Uniform brown, under surfaces pale or whitish. Spinous dorsal with outer part little deeper brown. Pectoral with some obscure brownish cloudings or blotches and also little deeper brown terminally. Fins otherwise pale to light brown.

Type-U.S.N.M. no. $98877 . \quad$ (4394.) D. 5316. Lat. $21^{\circ} 39^{\prime}$ N., long. $117^{\circ} 7^{\prime}$ E., China Sea. In 159 fathoms. November 5, 1908. Length $151 \mathrm{~mm}$.

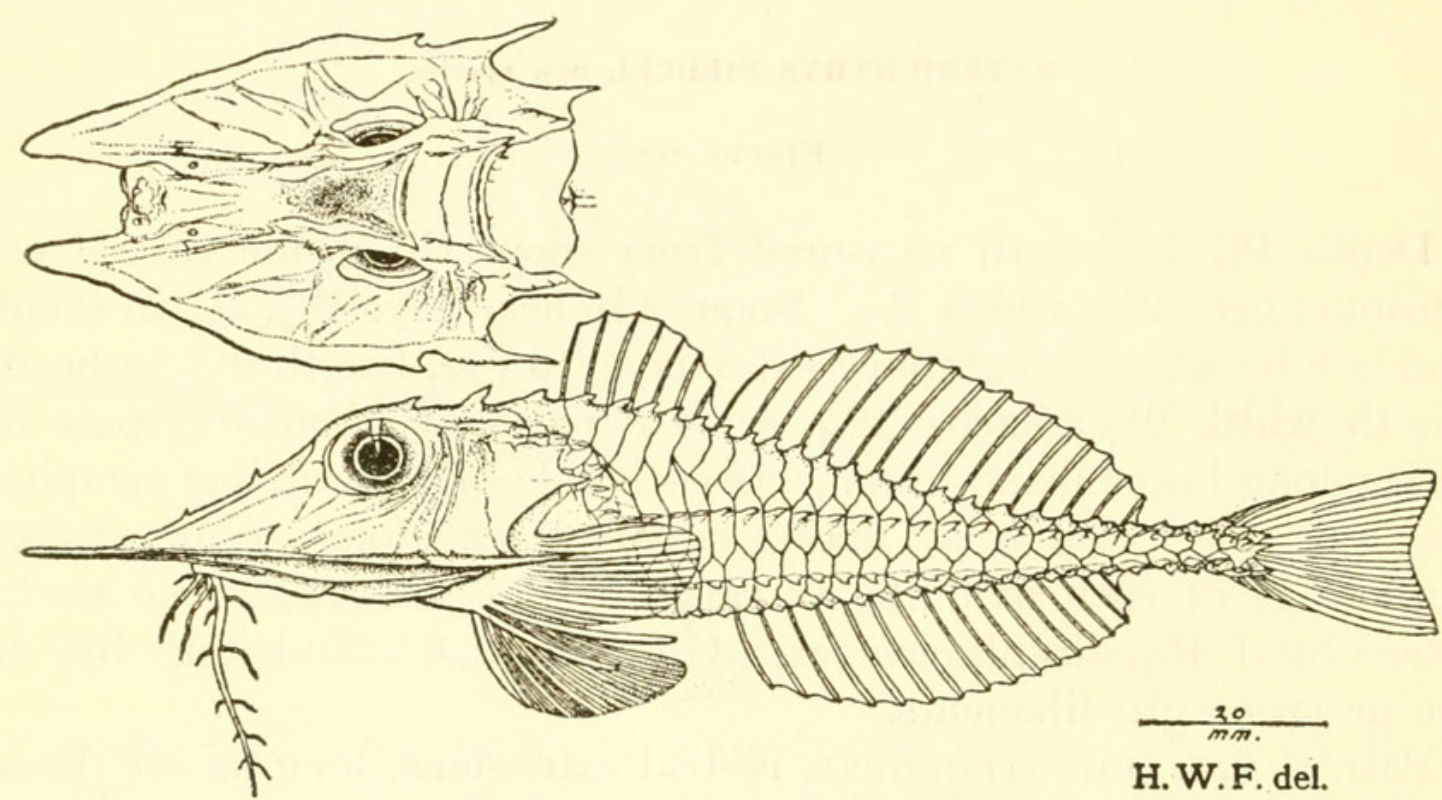

Figure 60.-Satyrichthys piercei, new species. Type.

Remarks.-Known only from the type. It differs from Nemaperistedion orientale in its greatly shorter barbel, though in many other respects is similar. Its rostral extensions are longer, and it is distinguished also by the presence of postnasal, rostral, and prebasal external preopercular spines.

(Named for Dr. Dwight L. Pierce, formerly of Iloilo, Philippines.)

\section{NEMAPERISTEDION, new genus}

Type.-Nemaperistedion orientale, new species.

Head as viewed from above of rather rhombic contour. Greatly elongated barbel reaches anal. Interorbital deeply concave. Preopercular spine long, reaches well on pectoral fin. No upper preopercular spine. Viewed from above rather wide interspace between rostral projections. Shields on belly rather broad.

Easily known by its very long barbels reaching vent or anal. ( $\nu \hat{\eta} \mu a$, thread + Peristedion; with reference to its long barbels.) 
Figure 61

Depth $4 \frac{1}{3}$ in length measured from snout tip inside rostral extensions; head $23 / 5$, width $1 \frac{1}{6}$. Snout $17 / 8$ in head; eye $43 / 5,21 / 5$ in snout, little greater than interorbital; maxillary extends $5 / 6$ to eye, length $21 / 8$ in head; mouth width 2 ; barbel long as head, reaches front of anal, with 10 pairs of filaments; 2 pairs anteriorly each side of lower mental filaments and 2 filaments on the inner edge of each mandibular ramus or chin, with posterior bifid; mouth edentulous; interorbital 5 in head; deeply concave, superciliary ridges elevated. Gill rakers $6+19$, of which 5 above and 1 below mere low rudiments; slightly longer than gill filaments or 4 in eye.

Pair of broad, flattened, rounded, rostral extensions, 11/6 in eye and interspace equals basal width of either extension; very small, short, median rostral spine at last fourth in snout; small anterosupraorbital spine each side, and pair of postero-supraorbital spines, posterior greatly larger and erect; pair of large erect diverging occipital spines; postocular keel ends in short, small obtuse suprascapular spine; small, slender opercular spine with distinct keel, its length $12 / 3$ in eye; edge of keel of suborbital stay unevenly and slightly undulated, ends behind in long slender preopercular spine reaching $1 / 3$ of pectoral, or its length subequal with eye; rather long asperous keel below and behind hind end of maxillary, followed by short one.

From above gill opening $34+1$ bony lateral plates; 4 rows of diminishing spiniferous plates on trunk and tail; spines all large, strong, erect, and surfaces of plates rough rugose; hind pair of plates on belly before vent $13 / 4$ in length of front pair ; row of 3 small plates, each bearing horizontal keel ending in short spine, above gill opening: and 3 similar subvertical or inclined plates behind gill opening.

D. VII, 20, second spine $4 \frac{1}{4}$ in head, fifth ray $4 \frac{1}{10}$; A. 23 , fourth ray $52 / 5$; caudal $2 \frac{1}{2}$, little concave behind, truncate as expanded; least depth of caudal peduncle $24 / 5$ in eye; pectoral $2 \frac{1}{8}$ in head, rays II, 12 , I-II, upper detached ray $2 \frac{1}{10}$ in head; ventral $2 \frac{1}{4}$, rays I, 5 .

Light brown, little paler to whitish below. Variable, scattered small brown spots on head and body above. Greater upper anterior portion of first dorsal blackish. Upper submarginal part of second dorsal anteriorly with narrow blackish brown streak. Pectoral slightly brownish submarginally. Fins otherwise all pale or whitish.

Type.-U.S.N.M. no. 98876. (3425.) D. 5623. Makyan Island, (S.) S. $88^{\circ}$ W., 7.5 miles (lat. $0^{\circ} 16^{\prime} 30^{\prime \prime}$ N., long. $127^{\circ} 30^{\prime} 00^{\prime \prime}$ E.), between Gillolo and Makyan Islands. In 272 fathoms. November 29, 1909. Length $179 \mathrm{~mm}$. 
Remarks.-Also a series of paratypes from the East Indies and Philippines, in 195 to 310 fathoms:

(2482.) D. 5317. Lat. $21^{\circ} 36^{\prime}$ N., long. $117^{\circ} 27^{\prime}$ E., China Sea, vicinity of Formosa. In 230 fathoms. November 5, 1908. Length $178 \mathrm{~mm}$.

(1961.) D. 5518. Point Tagolo Light, S. $64^{\circ}$ W., 8.7 miles (lat. $8^{\circ} 48^{\prime}$ N., long. $123^{\circ} 31^{\prime}$ E.), northern Mindanao and vicinity. In 200 fathoms. August 9, 1909. Length $143 \mathrm{~mm}$.

(1825.) D. 5222. San Andreas Island (W.), S. 57 ${ }^{\circ}$ E., 9.20 miles (lat. $13^{\circ} 38^{\prime} 30^{\prime \prime}$ N., long. $121^{\circ} 42^{\prime} 45^{\prime \prime}$ E.), between Marinduque and Luzon. In 195 fathoms. April 24, 1908. Length $141 \mathrm{~mm}$.

(4131.) D. 5626. Kayoa Island (SE.), S. $5^{\circ}$ W., 6.7 miles (lat. $0^{\circ} 7^{\prime} 30^{\prime \prime}$ N., long. $127^{\circ} 29^{\prime} 0^{\prime \prime}$ E.), between Gillolo and Kayoa Islands. In 265 fathoms. November 29, 1909. Length $171 \mathrm{~mm}$.

(3269.) D. 5625. Kayoa Island (SE.), S. $3^{\circ}$ W., 6 miles (lat. $0^{\circ} 7^{\prime} 0^{\prime \prime}$ N., long. $127^{\circ} 28^{\prime} 0^{\prime \prime}$ E.), between Gillole and Kayoa Islands. In 230 fathoms. November 29, 1909 . Length $175 \mathrm{~mm}$.

(1615.) D. 5590. Mabul Island (NW.), N. $22^{\circ}$ W., 4.3 miles (lat. $4^{\circ} 10^{\prime} 50^{\prime \prime}$ N., long. $118^{\circ} 39^{\prime} 35^{\prime \prime}$ E.), Sibuko Bay, Borneo, and vicinity. In 310 fathoms. September 29, 1909. Length $173 \mathrm{~mm}$.

(24238.) No label. Length $173 \mathrm{~mm}$.

(orientalis, eastern.)

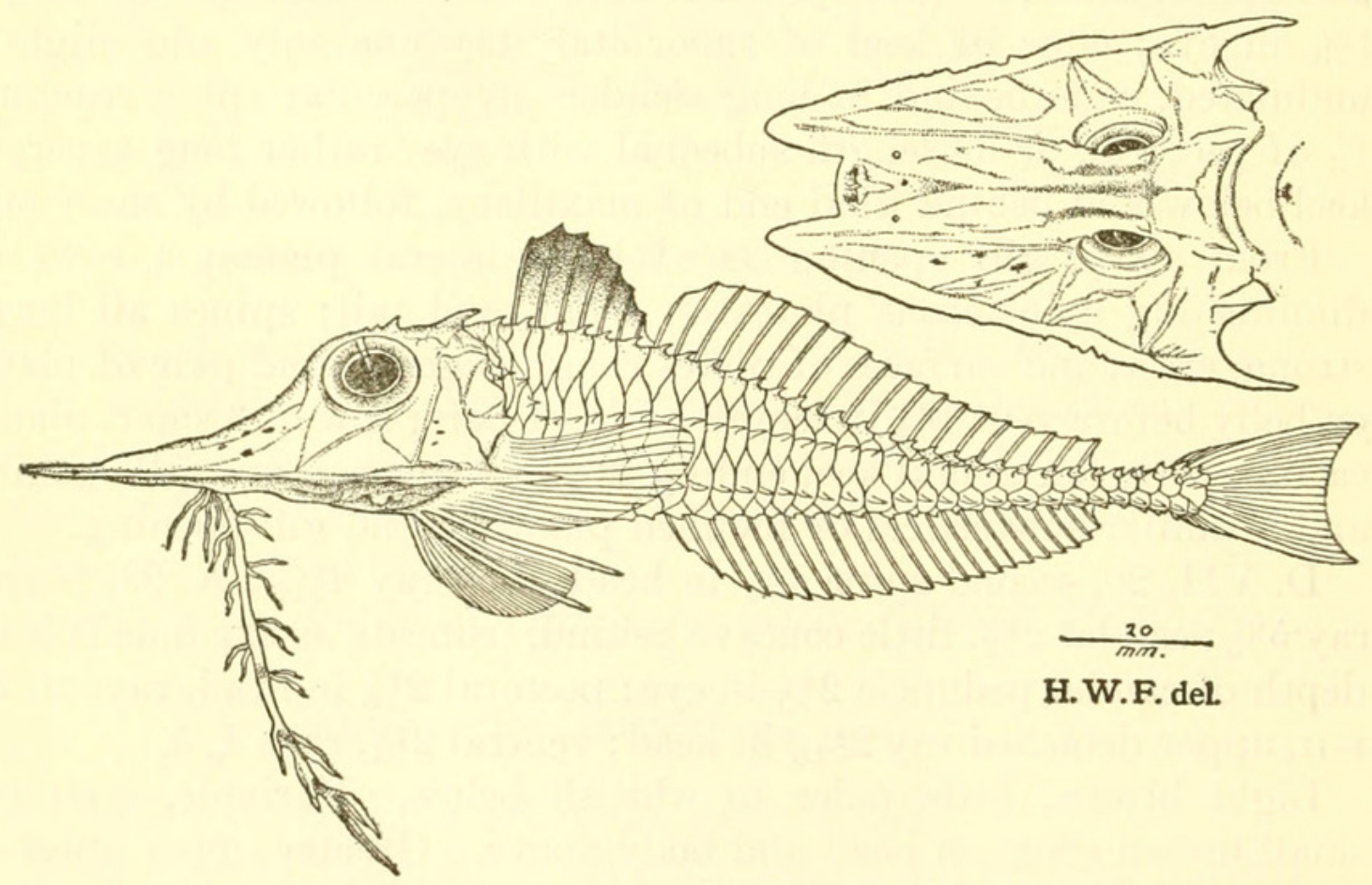

Figurw 61.-Nemaperistedion orientale, new species. 


\section{Family ELEOTRIDAE}

\section{SYNOPSIS OF GENERA}

$a^{\mathbf{1}}$. Head armed with one or more spines.

$b^{1}$. Einotrinae. Preopercle armed with single, small, more or less concealed spine directed down, or group of 3 to 5 small spines at angle; upper pectoral rays not silklike. (Type genus, Eleotris Schneider.)

$b^{2}$. Belobranchinat. Preopercle unarmed; one or more branchiostegals end in front on under surface of head in a strong spine directed forward and upward; upper pectoral rays silklike. (Type genus, Belobranchus Bleeker.)

$a^{2}$. Head without spines.

$c^{1}$. No mental tentacle.

$d^{1}$. Ophiocarinae. Head large, depressed, wide, lower jaw conspicuous. (Type genus, Ophiocara Gill.)

$e^{1}$. Head without skinny flaps; branched dorsal rays 8 or 9 ; caudal less than head; color pattern little variegated

Ophiocara

$e^{2}$. Head with skinny flaps; branched dorsal rays 10 ; caudal greater than head with age; color pattern greatly variegated. Batracheleotris

$d^{2}$. Valencienneinae. Head moderate, compressed. (Type genus, Valenciennea Bleeker.)

$f^{1}$. Dorsal spines usually elongated, sometimes front one may reach last dorsal ray.

$g^{1}$. Soft dorsal with spine and 12 to 18 branched rays; anal with spine and 12 to 17 branched

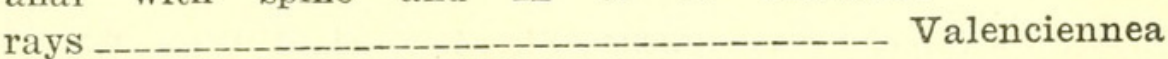

$g^{2}$. Soft dorsal with spine and 28 branched rays; anal with spine and 24 branched rays_-_-_-_-_-_-- Nemateleotris

$f^{2}$. Dorsal spines less than head; soft dorsal with spine and 11 branched rays; anal with spine and 12 rays; a dark transverse band across chest and another across middle of belly

Pteroculiops

$c^{2}$. Pogonoculinnae. Interspace between mandibular rami deep, with median free long tentacle; body with transverse bands. (Type genus, Pogonoculius, new genus.) _-_-_- Pogonoculius

\section{Subfamily OPHIOCARINAE}

\section{BATRACHELEOTRIS, new genus}

\section{Type.-Eleotris sclateri Steindachner.}

Body rather robust, especially forward, where more or less depressed. Head moderate, depressed, robust, long as trunk. Muzzle short, depressed, obtuse. Eye high, little advanced in head. Mouth short, broad, not reaching below eye, and lower jaw protruding little in front. Teeth strong, in bands in jaws. Tongue broad, rounded convexly in front. Interorbital very narrow bony ridge. Gill-openings lateral, vertical slit before pectoral base. Muzzle and wider 
surface of head naked, rest with small cycloid scales. Small cycloid scales crowded before dorsal forward to eyes, becoming large and coarsely ctenoid on tail. Very small cycloid scales on breast and belly. Muzzle with numerous short skinny flaps, and various rows of papillae on sides and upper surface of head. Vent with conic papilla. Two dorsals, first with 6 short flexible spines, second with spine and 10 rays. Anal with spine and 7 graduated rays. Caudal greater than head, ends in long median point behind. Pectoral long, reaches well beyond front of second dorsal or anal. Ventrals separated, little shorter than head.

Known by its variegated coloration, handsome mottling, long caudal fin, robust body, depressed head and trunk, and large eye.

Herre has described Gobiomorphus illotus from a specimen but $29 \mathrm{~mm}$ long from Polillo. This is surely not congeneric with Gill's Gobiomorphus, restricted to large species from New Zealand and apparently not at all like $G$. illotus. Possibly it may enter the present genus, though the large predorsal scales, different facies of the head shown with the interorbital elevated, lack of skinny flaps on the muzzle, greatly shorter fins, and lack of a greatly variegated color pattern seem to preclude the suggestion.

(Batrachus, a genus of toad fishes, or Batrachoididae, which these fishes superficially suggest + Eleotris.)

\section{BATRACHELEOTRIS SCLATERI (Steindachner)}

Eleotris sclateri Steindachner, Sitz.-Ber. Akad. Wiss. Wien, math.-nat. Classe, vol. 80, pt. 1 (1879), p. 157, 1880 (type locality, Society Islands).

Depth $47 / 8$ to $51 / 4$; head 3 to $33 / 5$, width $12 / 5$ to $1 \frac{1}{2}$. Snout $33 / 4$ to 4 in head measured from snout tip; eye $34 / 5$ to 4 , subequal with snout, greatly exceeds interorbital; maxillary reaches eye, length $24 / 5$ to $31 / 2$ in head from snout tip; teeth simple, pointed, conic, close set, in narrow bands in jaws; interorbital low, narrow, half wide as eye. Gill slit lateral, restricted, equals mouth width.

Scales $33+4$ in axial lateral series from suprascapula; 15 transversely above anal origin, 16 to 19 predorsal forward opposite hind eye edge, 7 rows on cheek below eye. Muzzle, interorbital and branchiostegal region naked. Scales much smaller on chest, breast, prepectoral and predorsal regions, largest on tail and caudal peduncle. Scales with 24 to 32 radiating striae; apical denticles large, uniserial, only on scales of tail; circuli coarse on anterior or small scales, larger scales with fine circuli which obsolete apically.

D. VI-I, 10, I, spines flexible with third 2 in total head, first branched ray $17 / 8$ to 2 ; A. I, 7 , I, seventh ray $1 \frac{1}{4}$ to $14 / 5$; least depth of caudal peduncle $2 \frac{1}{5}$ to $21 / 4$; pectoral $1 \frac{1}{10}$ in total head to 3 in fish 
without caudal; caudal $1 \frac{1}{8}$ in total head to $21 / 3$ in rest of fish; ventral $11 / 8$ to $1 \frac{1}{3}$ in total head. Anal papilla $17 / 8$ in eye.

Brown, paler to whitish on under surface of head and belly. Cheek or side of head below eye mottled with pearl white and russet, or burnt umber. Warm-brown band transversely from one pectoral base to the other, another darker and more contrasted band from base of spinous dorsal, two from soft dorsal and one on side of caudal peduncle. Whole upper surfaces more or less mottled with pearly and deep brown. Iris gray with pearl and brown tints. Fins largely gray or white, spinous dorsal with blackish brown median blotch, two large ones on soft dorsal, and other fins with rather numerous blackish brown blotches. In small examples fins all more whitish, with blotches paler or brownish, or forming several dark transverse bands on caudal and paired fins. Head usually with some small blackish brown specks or dots. Usually dark brown preorbital bar, which may be reflected across the mandible.

Philippines, East Indies. A very pleasing little fish, with attractive coloration. The following specimens in the Philippine material :

Two examples. Batan Island, tide pools. June 5, 1909. Length 36 to $48 \mathrm{~mm}$. Five examples. Batan Island, tide pools. July 22, 1909. Length 31 to $47 \mathrm{~mm}$.

Four examples. Canimo Island, near Daet, tide pool. June 15, 1909. Length 37 to $51 \mathrm{~mm}$.

Seven examples. Great Tobea Island, December 15, 1909. Length 25 to $56 \mathrm{~mm}$.

Five examples. Gubat Bay, tide pool. June 23, 1909. Length 33 to $47 \mathrm{~mm}$. (1690.)

Four examples. Mahinog, Camiguin Island, tide pools. August 3, 1909. Length 35 to $44 \mathrm{~mm}$.

Six examples. Nasipit, Mindanao, tide pools. August 1, 1909. Length 16 to $22 \mathrm{~mm}$.

One example. Simaluc Sibi Sibi Island, tide pools. September 23, 1909. Length $52 \mathrm{~mm}$.

One example. Tomahu Island. December 12, 1909. Length $37 \mathrm{~mm}$.

\section{Subfamily VALENCIENNEINAE}

\section{NEMATELEOTRIS, new genUS}

\section{Type.-Nemateleotris magnificus, new species.}

Body elongate, well compressed. Head small, compressed, greatly shorter than trunk. Snout very short, obtuse. Eye large, greatly exceeds snout or muzzle, well advanced in head, impinging on upper profile of head. Mouth moderate, terminally superior or with mandible little protruded in front. Teeth uniserial, large, simple, well spaced. Maxillary oblique, extends below eye. Interorbital rather broad. Head unarmed, without spines. Gill opening lateral, oblique, 
rather close before pectoral. Scales present on trunk and tail, very small on predorsal, chest and breast, large on prepectoral and on tail posteriorly. Two dorsals, first of 6 slender spines of which first prolonged as filament, which would reach base of last dorsal ray, and soft fin with spine and 28 rays. Anal little shorter than soft dorsal, with spine and 24 rays. Caudal rather large, ends posteriorly in median point (now damaged). Pectoral short, low. Ventrals well separated, inserted little before pectoral base, slender, moderate.

I name this genus for an exquisite little eleotrid, with its second and third dorsal spines ending in a prolonged filament; peculiar facies of head with very short snout, large eye and strong jaws, and long soft dorsal and anal; also a color pattern of greatly pleasing and contrasted design.

$(\nu \hat{\eta} \mu a$, thread +Eleotris; with reference to the elongated, filamentous, first dorsal spine.)

\section{NEMATELEOTRIS MAGNIFICUS, new species}

Depth 5 ; head $41 / 4$, width 2 . Snout 5 in head from snout tip; eye 3 , greatly exceeds snout, equals interorbital; maxillary extends below first third of eye, length $2 \frac{1}{2}$ in head from snout tip; teeth strong, conic, sharp pointed, about 20 in each jaw; interorbital 3, low, depressed concavely. Gill opening restricted, lateral, length $2 \%$ in head from snout tip, with rather broad isthmus exposed.

Scales $108+10$ in axial lateral series; 27 transversely above anal origin. Scales very small and crowded on front sides of back, chest, breast and belly. Caudal base scaly, otherwise fins naked. Scales with 11 basal radiating striae; 8 to 12 rather large uniserial apical denticles; circuli fine, obsolete apically.

D. VI-I, 28, I, first spine prolonged filament so as to reach base of last ray, fifth ray $1 \frac{1}{3}$ in total head length; A. I, 24, I, eighth ray $14 / 7$; caudal $31 / 3$ in rest of fish, ends posteriorly in median point (damaged) ; pectoral $1 \frac{1}{10}$ in total head length, rays 17 ; ventral rays $I$, 5 , fin 1 in total head length; least depth of caudal peduncle $13 / 4$.

Light brown generally, little paler to whitish on under surface of head and belly. Iris gray-white. Dorsals and anals largely whitish, long filament grayish. Soft dorsal with broad upper border gray black, little above middle each membrane with large black blotch, convex above and concave below so white of fin forms more or less of ocellate appearance, also each membrane with basal whitish area with 3 to 6 small dark gray round spots. Anal with lower border gray black and then band made up of black ocellate spot on each membrane. Caudal pale basally, blackish above and below, and oblique black bar converging medially behind on each lobe. Paired fins dull brown.

The diagnosis is contained in the generic account. 
Type-CU.S.N.M. no. 99044. (2060.) Buka Buka Island, Gulf of Tomini, Celebes, Dutch East Indies. November 20, 1909. Length $61 \mathrm{~mm}$.

(magnificus, splendid.)

\section{PTEROCULIOPS, new genus}

Type.-Pteroculiops guttatus, new species.

Body moderately long, well compressed. Head moderate, well compressed, longer than trunk. Muzzle short, broad, declivous. Eye elevated, and advanced in head. Mouth rather large, extends well below eye, mandible little protruded. Lips rather broad, fleshy. Tongue rounded in front. Teeth in narrow band above, uniserial below, and each jaw with canines as 2 pairs above and single wide set lower pair. Interorbital narrow bony frenum. Gill opening: moderate, extends forward about opposite hind preopercle edge. Gill rakers lanceolate, short, few. Scales extend forward halfway in predorsal, when obsolete, head otherwise naked. Scales on body finely ctenoid, very small on trunk, breast and belly and become larger on tail, especially posteriorly. Dorsals two, first of 6 flexible spines, second with spine and 11 rays. Anal with spine and 12 rays. Caudal long as ventral, or both longer than head. Pectoral little shorter.

Distinguished chiefly by its very long ventrals, naked head, and coloration with scattered blue-gray round spots, also transverse dark diffuse band across chest and another across middle of belly. It appears allied with Valencienneia in the presence of canines, though with much larger scales (about 54).

$$
(\pi \tau \epsilon \rho \dot{\nu}, \text { fin }+ \text { Culius }+\ddot{\omega} \psi \text {, appearance. })
$$

\section{PTEROCULIOPS GUTTATUS, new species}

Depth 4; head 3, width 2. Snout $47 / 8$ in head from snout tip; eye 4 , greater than snout, greatly exceeds interorbital; maxillary extends $3 / 4$ in eye, length $21 / 10$ in head from snout tip; lips thick and fleshy; teeth strong, canines bent back, lower pair lateral as one on each mandibular ramus medially; interorbital narrow, low, width 1/4 of eye. Gill rakers $5+11$, lanceolate, $3 / 4$ of gill filaments or 3 in eye. Scales $64+5$ in axial lateral series; 19 above anal origin transversely, 19 predorsal forward opposite hind preopercle edge. Head naked. Scales with 9 to 11 basal radiating striae; 11 apical denticles, rather large, uniserial; circuli fine.

D. VI-I, $11, \mathrm{I}$, fourth spine $13 / 7$ in total head length, first branched ray 2 ; A. I, $12 \mathrm{I}$, first branched ray $22 / 3$; caudal 3 in rest of fish, ends in median point behind; least depth of caudal peduncle $27 \%$ in total head length; pectoral 11/6, rays 20 ; ventral rays I, 5, fin 1 in total head length. 
Brown, little paler below. Chest, branchiostegal region, and isthmus dark chocolate, also a broad chocolate band transversely across middle of postventral region, up each side level with pectoral fin. Iris silvery gray. Head and body with many variable, mostly, large rounded blue-gray spots, more or less ringed with darker brown. Fins all pale gray brown, anal dark brown terminally, and both soft dorsal and anal with 4 basal blue-gray large spots. Pectoral pale yellowish brown. Ventral gray brown outside, gray black inside or toward belly.

Diagnosis included in that of the genus. Only the type known. Type.-U.S.N.M. no. 99045. (1169.) Port Banalakan, Marinduque Island. February 23, 1909. Length $69 \mathrm{~mm}$.

(guttatus, spotted.)

\section{Pogonoculinat, new subfamily}

\section{POGONOCULIUS, new genus}

\section{Type.-Pogonoculius zebra, new species.}

Body elongate, greatly compressed. Head small, short, compressed. Snout short, obtuse. Eye moderate, well advanced and high in head. Mouth terminally superior, subvertical. Mandibular bones well separated, protrude before snout, interspace of chin deep, with median free tentacle nearly long as combined snout and eye, and followed by dermal ridge to isthmus. Teeth large, simple, uniserial. Gill openings lateral. Body largely scaled, small irregular scales only distinct on tail posteriorly. Two dorsals, spines 6, rays 28. Anal rays 26, fin like second dorsal and opposite. Caudal peduncle short, free. Caudal moderate, truncate. Pectoral short, rounded, with broad base. Ventrals close, distinctly separated and much longer than pectorals. Vent close before anal.

Unique in the mental tentacle and combination of structural characters, such as the small head, long ventrals, strong dentition, long second dorsal and anal, etc. It is perhaps related to Ptereleotris Gill, differing sharply in the characters noted above, especially its obsolete lepidosis, coloration, general appearance, and other characters.

( $\pi \dot{\omega} \gamma \omega \nu$, beard + Culius, an old name for Eleotris.)

\section{POGONOCULIUS ZEBRA, new species}

Depth $5 \frac{1}{3}$; head $43 / 5$, width $13 / 4$. Snout 5 in head from snout tip; eye 4, greater than snout, equals interorbital; maxillary subvertical, reaches $4 / 5$ to eye, length 3 in head from snout tip; teeth conic, large, well spaced, sharp pointed, 10 in each jaw, none on palate; interorbital 
$33 / 5$ in head from snout tip, low, convex. Gill opening restricted, leave moderately narrow isthmus.

Scales minute, nonimbricate, rounded, imperfectly developed, or only on tail where more numerous posteriorly.

D. VI-28, I, last spine $12 / 3$ in total head length, first ray $13 / 4 ;$ A. 26 , I, second ray $13 / 4$; caudal 1 , truncate; least depth of caudal peduncle 2 ; pectoral $11 / 8$, rays 23 ; ventral $I$, 4 , fin 1 in head.

Brown, scarcely paler below, with 21 narrow pale brown transverse bands, narrower than dark interspaces, and each with dark brown bordering line. Iris grayish. Fins all light brown like general body color, only upper edge of both dorsals narrowly black with submarginal gray line. Broad pale brown transverse band on pectoral base, its front and hind margins each with dark brown bordering line.

Diagnosis contained in the description of the genus.

Type.-U.S.N.M. no. 99048. (1535.) Dasol Bay. May 8, 1909. Length $95 \mathrm{~mm}$.

(zebra, with reference to the striped appearance.) 


\section{$2 \mathrm{BHL}$ Biodiversity Heritage Library}

Fowler, Henry W. 1938. "Descriptions of new fishes obtained by the United States Bureau of Fisheries steamer "Albatross", chiefly in Philippine seas and adjacent waters." Proceedings of the United States National Museum 85, 31-135. https://doi.org/10.5479/si.00963801.85-3032.31.

View This Item Online: https://www.biodiversitylibrary.org/item/32776

DOI: https://doi.org/10.5479/si.00963801.85-3032.31

Permalink: https://www.biodiversitylibrary.org/partpdf/29660

\section{Holding Institution}

Smithsonian Libraries

\section{Sponsored by}

Smithsonian

\section{Copyright \& Reuse}

Copyright Status: NOT_IN_COPYRIGHT

Rights: https://www.biodiversitylibrary.org/permissions/

This document was created from content at the Biodiversity Heritage Library, the world's largest open access digital library for biodiversity literature and archives. Visit BHL at https://www.biodiversitylibrary.org. 